\title{
33. GEOCHEMISTRY OF IGNEOUS ROCKS RECOVERED FROM A TRANSECT ACROSS THE MARIANA TROUGH, ARC, FORE-ARC, AND TRENCH, SITES 453 THROUGH 461, DEEP SEA DRILLING PROJECT LEG 601
}

\author{
D. A. Wood, ${ }^{2}$ N. G. Marsh, ${ }^{2}$ J. Tarney, ${ }^{2}$ J.-L. Joron, ${ }^{3}$ P. Fryer,,${ }^{4}$ and M. Treuil ${ }^{3}$
}

\begin{abstract}
Major and trace element analyses are presented for 110 samples from the DSDP Leg 60 basement cores drilled along a transect across the Mariana Trough, arc, fore-arc, and Trench at about $18^{\circ} \mathrm{N}$. The igneous rocks forming breccias at Site 453 in the west Mariana Trough include plutonic cumulates and basalts with calc-alkaline affinities. Basalts recovered from Sites 454 and 456 in the Mariana Trough include types with compositions similar to normal MORB and types with calc-alkaline affinities within a single hole. At Site 454 the basalts show a complete compositional transition between normal MORB and calc-alkaline basalts. These basalts may be the result of mixing of the two magma types in small sub-crustal magma reservoirs or assimilation of calc-alkaline, arc-derived vitric tuffs by normal MORB magmas during eruption or intrusion.

A basaltic andesite clast in the breccia recovered from Site 457 on the active Mariana arc and samples dredged from a seamount in the Mariana arc are calc-alkaline and similar in composition to the basalts recovered from the Mariana Trough and West Mariana Ridge. Primitive island arc tholeiites were recovered from all four sites (Sites 458-461) drilled on the fore-arc and arc-side wall of the trench. These basalts form a coherent compositional group distinct from the Mariana arc, West Mariana arc, and Mariana Trough calc-alkaline lavas, indicating temporal (and perhaps spatial?) chemical variations in the arc magmas erupted along the transect.

Much of the 209 meters of basement cored at Site 458 consists of endiopside- and bronzite-bearing, Mg-rich andesites with compositions related to boninites. These andesites have the very low $\mathrm{Ti}, \mathrm{Zr}, \mathrm{Ti} / \mathrm{Zr}, \mathrm{P}$, and rare-earthelement contents characteristic of boninites, although they are slightly light-rare-earth-depleted and have lower $\mathrm{MgO}$, $\mathrm{Cr}, \mathrm{Ni}$, and higher $\mathrm{CaO}$ and $\mathrm{Al}_{2} \mathrm{O}_{3}$ contents than those reported for typical boninites. The large variations in chemistry observed in the lavas recovered from this transect suggest that diverse mantle source compositions and complex petrogenetic process are involved in forming crustal rocks at this intra-oceanic active plate margin.
\end{abstract}

\section{INTRODUCTION}

On DSDP Legs 59 and 60,15 sites were drilled along an east-west transect at about $18^{\circ} \mathrm{N}$ from the West Philippine Basin to the Mariana Trench (Fig. 1) in order to study the nature of the back-arc and inter-arc basins, the remnant and active arcs, and the fore-arc of the region. One of the many aims of this drilling program was to elucidate the processes involved in crustal generation and the composition variation of active margin volcanics in an intra-oceanic environment, free of the complications associated with arc systems close to continental margins. On Leg 60, we recovered igneous rocks from the Mariana Trough, Sites 453, 454, and 456; the Mariana Ridge, Site 457; the Mariana fore-arc, Sites 458 and 459; and the arc-side wall of the Mariana Trench, Sites 460 and 461.

Detailed geophysical investigations and dredging operations have established that most back-arc or interarc basins are of extensional origin and are floored by basaltic crust, broadly comparable in structure and

\footnotetext{
1 Initial Reports of the Deep Sea Drilling Project, Volume 60

2 Department of Geological Sciences, University of Birmingham, P.O. Box 363, Birmingham, B15 2TT, U.K. Dr. Wood's present address: Phillips Petroleum Co. Europe Africa, Glen House, Stag Place, London SWIE SDA, U.K. Dr. Marsh's present address: University of Leicester, Department of Geology, Leicester, LEI 7R4, U.K.

${ }^{3}$ Laboratorie de Géochimie Comparée et Systematique, UER des Sciences de la Terre et Institut de Physique du Globe, LA 196 CNRS, Université Pierre et Marie Curie, 4 Place Jussieu, 75230 Paris Cedex 05, France, and Laboratoire Pierre Sue CNRS, CEN Saclay, B. P. No. 2, 91190 Gif-sur-Yvette, France.

$4^{4}$ Hawaii Institute of Geophysies, 2525 Collea Road, Honolulu, Hawaii 96822.
}

composition to those of the major ocean basins (Karig, 1971; Hart et al., 1972; Barker, 1972; Hawkins, 1974; Gill, 1976). Recent studies have shown that some of the basalts flooring back-arc basins are enriched in volatile and mobile elements (e.g., $\mathrm{H}_{2} \mathrm{O}^{+}, \mathrm{K}, \mathrm{Rb}, \mathrm{Ba}, \mathrm{Sr}, \mathrm{U}$, and $\mathrm{Cs})$ relative to normal mid-ocean ridge basalts (N-type MORB), and have some affinities with active margin magma types (Gill, 1976; Tarney et al., 1977; Hawkesworth et al., 1978; Saunders and Tarney, 1979; Weaver et al., 1979). In contrast, the basalts drilled in the Shikoku, West Philippine, and Parece Vela Basins on Legs 58 and 59 show no unequivocal chemical affinities with active margin magma types (Marsh et al., 1980, Mattey et al., 1980; Wood et al., 1980a, 1980b). The basalts recovered from the Mariana Trough provide us with an opportunity to compare the compositions of material from this relatively recently developed, narrow inter-arc basin with those of the broader, more mature back-arc basins of the West Pacific Ocean.

There is as yet no general consensus on the petrogenetic processes of active arc magma types. There are two main compositional end members of arc magmatism: a tholeiitic type showing iron enrichment trends and a calc-alkaline type showing enrichment in alkalis, corresponding broadly to Kuno's (1968) pigeonitic and hypersthenic series, respectively. In addition, there are very rare $\mathrm{Mg}$-rich andesites or boninites, named after their type locality in the Bonin Islands (Kuroda and Shiraki, 1975) but also recently dredged from the Mariana Trench near the island of Guam (Dietrich et 


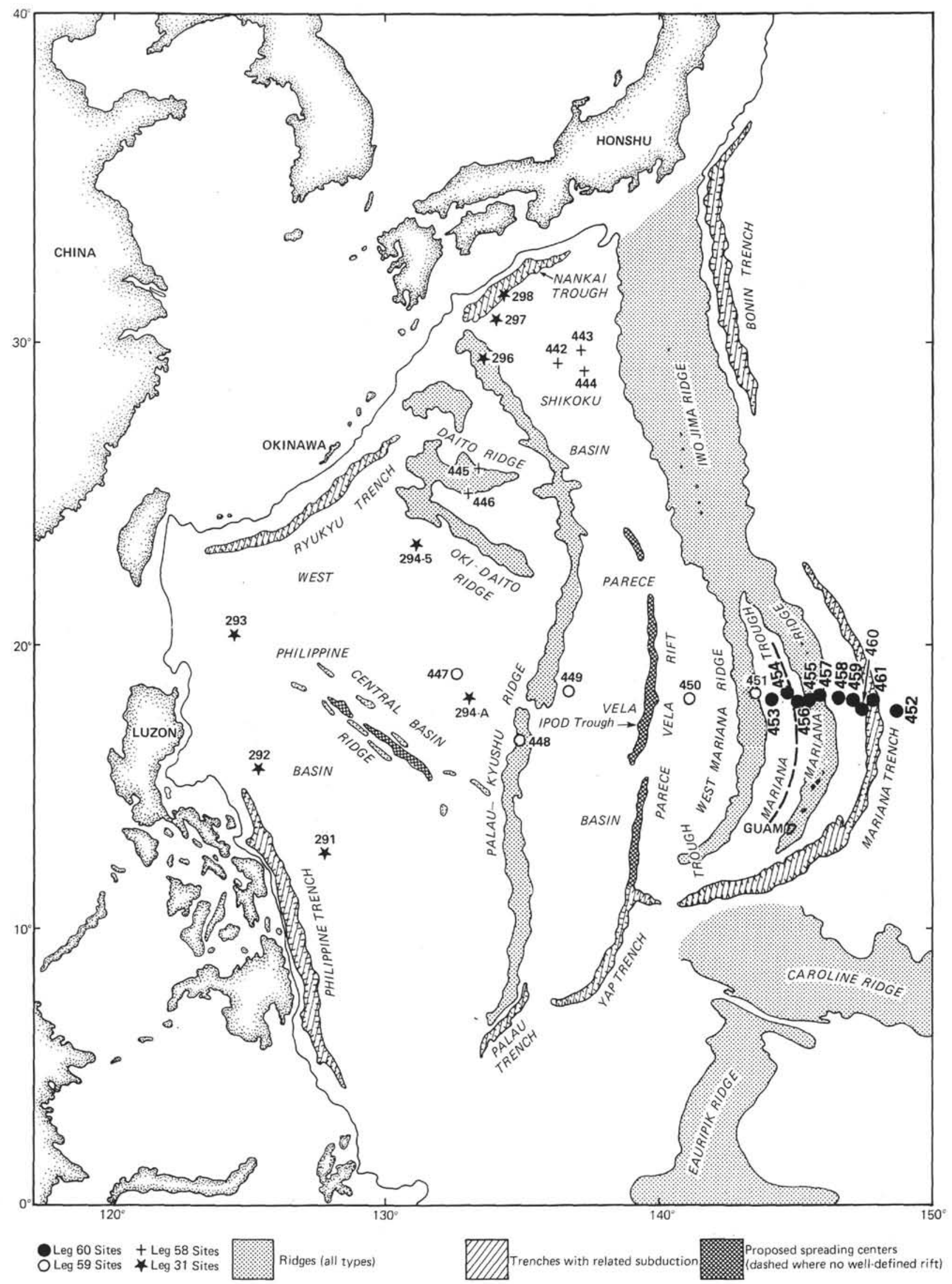

Figure 1. Location of drill sites from Legs 59 and 60. 
al., 1978). These lavas are thought to be produced during the early stages of island arc development and are therefore important in understanding arc magmatism. Similar Mg-rich andesites were drilled at Site 458. These lavas, together with the primitive island arc tholeiites and calc-alkaline basalts recovered from the KyushuPalau, West Mariana, Mariana Ridges and the Mariana fore-arc and Trench during Legs 59 and 60 , should help to constrain petrogenetic models for this tectonic environment.

\section{REGIONAL AND TECTONIC SETTING}

The southern Philippine Sea is divided into three major basins (Fig. 1) which are elongated in a north-south direction. From west to east the basins are: the West Philippine Basin, the Parece Vela Basin, and the Mariana Trough. The basins are separated by the KyushuPalau and West Mariana Ridges, respectively. The eastern boundary of the Southern Philippine Sea consists of the Mariana Arc and fore-arc, which overlie the Pacific plate presently being subducted at the Mariana Trench (Katsumata and Sykes, 1969).

The Mariana Trough is crescent-shaped, open at its southern end but closing at the junction between the Mariana and West Mariana Ridges in the north. The trough is approximately $1500 \mathrm{~km}$ long and $250 \mathrm{~km}$ across at its widest section. The Mariana Ridge is approximately 100 to $120 \mathrm{~km}$ across, and the fore-arc, or arc-trench gap, is approximately 150 to $180 \mathrm{~km}$ wide.

The crust flooring the Mariana Trough is characterized by rough topography (Hart et al., 1972) and high heat flow (Sclater et al., 1972). It is underlain by a mantle zone of high seismic wave attenuation (Barazangi et al., 1975). Poorly developed magnetic lineations have been reported for the Mariana Trough (Hussong, Uyeda, et al., 1978). The reasons for the poorly developed magnetic lineations are suspected to be the rough basement topography and low geomagnetic latitude of the region (Karig et al., 1978). On the basis of the sediment thickness, depth, the character of the acoustic basement, and the presence of a topographic axial high and mean heat flow, Karig (1971) suggested that the Mariana Trough is actively spreading, unlike the other basins of the Philippine Sea. Estimates for the spreading rate vary from slow, $1 \mathrm{~cm} \mathrm{yr}^{-1}$ (Hart et al., 1972) and $2 \mathrm{~cm}$ $\mathrm{yr}^{-1}$ (Hussong et al., 1978), to fast, and $4 \mathrm{~cm} \mathrm{yr}^{-1}$ (Karig et al., 1978). The uppermost crust in the axial region of the trough consists of basalts broadly similar to ocean floor tholeiites (Hart et al., 1972; Hawkins, 1977). The opening of the Mariana Trough appears to be a continuation of the processes involved with the opening of the Parece Vela and Shikoku Basins, to the west, during the middle to late Tertiary. However, the relationship of these eastern basins and ridges to the West Philippine Basin remains uncertain (Scott et al., 1980).

The Mariana arc can be divided into two sections: a northern section which is presently active and underlain by a steeply dipping Benioff zone, with seismic activity down to at least $600 \mathrm{~km}$; and a southern section which is presently inactive and underlain by a poorly defined seismic zone less than $200 \mathrm{~km}$ deep (Katsumata and Sykes, 1969; Isacks and Barazangi, 1977). The two zones overlap between $16^{\circ}$ and $17^{\circ} 30^{\prime} \mathrm{N}$, the ridge of the southern section lying to the trench side. The northern ridge carries 10 subaerial volcanic islands and possibly several submarine volcanoes whose extrusive products are dominated by quartz-normative basalts and basaltic andesites. The lack of iron enrichment and high $\mathrm{Ba}$ and $\mathrm{Sr}$ contents in the basalts suggests that they have calc-alkalic affinities (Meijer, 1976; Dixon and Batiza, 1979). The volcanic islands of the southern ridge consist mainly of basalts and basaltic andesites interbedded with and overlain by, predominantly calcareous sediments (Stark, 1963), although more evolved igneous rocks occur, for example, dacite on Saipan (Cloud et al., 1956; Schmidt, 1957; Taylor et al., 1969). These lavas also lack a trend of strong iron enrichment and plot as a hypersthenic series on an AFM diagram (Stark, 1963). In contrast to the Mariana arc and trough, the fore-arc has not been studied in detail. It consists of crust which is seismically oceanic in character (Murauchi et al., 1968). Sedimentation on the fore-arc appears to be strongly controlled by tectonic activity, mainly block faulting in a tensional regime with subsidence since the early Tertiary. It is unlikely that slices of the main Pacific ocean floor have been imbricated into the fore-arc of the Mariana system (Hussong et al., 1978).

The Mariana Trench has been dredged previously during Cruise 17 of the RV Dmitry Mendeleev south of the Leg 60 transect, at approximately $12^{\circ} \mathrm{N}$ (Anonymous, 1977). The dredges recovered flysch-like sediments, gabbros, metagabbros, serpentinized and mylonitized periodotites, boninites, basalts, and metabasalts (Dietrich et al, 1978; Sharaskin et al., 1980). The boninites and flysch-like sediments suggest the presence of arc-derived material in the trench.

\section{ANALYTICAL METHODS}

We have analyzed 110 samples from the Leg 60 cores at Birmingham by X-ray fluorescence (XRF) for major and trace elements by the method given in Tarney et al. (1978). However, $\mathrm{TiO}_{2}, \mathrm{MgO}, \mathrm{CaO}$, and $\mathrm{Na}_{2} \mathrm{O}$ were analyzed using an $\mathrm{Rh}$ anode tube rather than a $\mathrm{Cr}$ anode tube. Instrumental conditions for major element analysis using an Rh anode X-ray tube are given by Marsh et al. (1980). We have also analyzed 63 samples from the Leg 60 sites at Saclay by instrumental neutron activation (INA) for additional trace elements by the method of Chayla et al. (1973).

\section{RESULTS}

The XRF data, together with CIPW norms and some trace element ratios, are given in Tables 1 through 6, 8, and 10. Some of the INA data have been presented by Bougault et al. (this volume), and only representative analyses of the main lithological units are given here (Table 11). The geochemical variations of the Leg 60 sites will be dealt with in two parts: first, the Mariana Trough and Ridge sites (Sites 453, 454, 456, and 457); and secondly, the Mariana fore-arc and Trench sites (Sites 458 through 461). This will be followed by a brief, essentially qualitative, discussion of the implications of the geochemical data for the processes involved in the 
petrogenesis of this diverse suite of active plate margin volcanics.

\section{The Mariana Trough and Ridge}

\section{Site 453 \\ $\left(17^{\circ} 54.42^{\prime} \mathrm{N}, 143^{\circ} 40.95^{\prime} \mathrm{E}\right)$}

This site was located $120 \mathrm{~km}$ west of the central graben of the Mariana Trough in a water depth of 4693 meters. The 150 meters of igneous and metamorphic polymict breccias recovered are more than $5.4 \mathrm{~m}$.y. old and are predominantly gabbros with subordinate norites and metabasalts cemented by a calcite, clay and/or iron oxide matrix. The breccia sequence can be split into three units based on lithologic changes with depth in the hole. These are:

1) From 455.5 to 541 meters, sub-bottom depth (Cores 49 through 57), an igneous polymict breccia of large gabbroic clasts $(>10 \mathrm{~cm})$ with a few diabase and basalt clasts in a predominantly red-brown matrix. The core from Section 55-4 (Piece 4) through Section 57-2 (Piece 16), however, has a green matrix and the gabbros in it have been demagnetized as a result of hydrothermal alteration at elevated temperatures.

2) From 541 to 569.5 meters, sub-bottom depth (Cores 58 through 60), an igneous polymict breccia of predominantly metavolcanic clasts. Quartz veining is common, and pyrite is abundant in the matrix.

3) From 569.5 to 605 meters, sub-bottom depth (Cores 61 through 64), a breccia composed of sheared, mylonitized and serpentenized metagabbro clasts, with abundant pyrite set in a matrix of serpentine.

The analyzed samples cover virtually the full spectrum of gabbroic clasts recovered, which include gabbros, anorthositic gabbros, gabbro pegmatites, noritic gabbros, and hornblende gabbros. Hand-specimen descriptions of the analyzed clasts are given in the Appendix. Replacement of the original igneous mineral assemblage of plagioclase \pm clinopyroxene \pm orthopyroxene \pm olivine \pm brown hornblende \pm accessory magnetite is common. Replacement minerals include green hornblende, chlorite, epidote, sericite, carbonates, clays, and alkali feldspars with accessory amounts of zeolites, prehnite, pumpellyite, and stilpnomelane. The volcanic clasts recovered are mainly doleritic in texture and aphyric to sparsely plagioclase phyric with rare small vesicles $(<0.6 \mathrm{~mm})$. Alteration is moderate to heavy with clinopyroxene being replaced by chlorite, stilpnomelane, and iron oxides, and plagioclase being replaced by sericite, albite, and clays.

The major and trace element chemistry of the plutonic rocks (Table 1) is consistent with many of them being cumulates (Figs. 2 and 3), which accounts for the very low abundances of several of the incompatible or hygromagmatophile (HYG) trace elements (e.g., $\mathrm{Zr}$ and $\mathrm{Y}$ ) in some of the samples. The basaltic clasts vary from aphyric to sparsely plagioclase, and clinopyroxene phyric with rare pseudomorphs of olivine microphenocrysts. The compositions of these basaltic clasts are typical of arc magma types with high $\mathrm{Sr}$ and $\mathrm{Ba}$ but low $\mathrm{Ta}$, $\mathrm{Cr}$, and $\mathrm{Ni}$ contents. Of the two basalts analyzed by
INA (Table 10), Sample 453-52-1, 30-36 $\mathrm{cm}$ has a more primitive arc tholeiite composition (lower $\mathrm{Th}$ and $\mathrm{La}$ and a depletion in the light rare earth elements (REE) relative to the heavy REE (i.e., chrondite-normalized $\mathrm{La} / \mathrm{Tb}$ ratio less than 1 ).

The high $\mathrm{Sr}$ and $\mathrm{Ba}$ contents of the plutonic rocks from this site (Table 1) are consistent with an origin in the deep-seated portion of an island arc. Table 2 presents major and trace element analyses of plutonic rocks from the Masirah ophiolite, Indian Ocean crust (Abbotts, 1979) and calc-alkaline plutonic rocks from Chile (Marsh, 1977; Wells, 1978). Note the lower Sr and $\mathrm{Ba}$ of the plutonic rocks from oceanic crust relative to the rocks from Site 453. However, the very high $\mathrm{Ba}$ and $\mathrm{K}_{2} \mathrm{O}$ contents of some Site 453 samples (e.g., Sample 453-52-4, 0-4 cm) are likely to be due to the presence of secondary potassium feldspar. The most plausible explanation for these breccias is a derivation from the West Mariana Ridge during the uplift resulting from the initial rifting of the Mariana Trough. We note that the basalt clasts in the breccia drilled on Site 451 (Leg 59) on the West Mariana Ridge also have calc-alkaline affinities (Mattey et al., 1980; Wood et al., 1980a). However, calc-alkaline magmas may have been erupted elsewhere in the Mariana Trough (see the following).

\section{Site 454 \\ $\left(18^{\circ} 00.78^{\prime} \mathrm{N}, 144^{\circ} 31.92^{\prime} \mathrm{E}\right)$}

This site was located $28 \mathrm{~km}$ west of the central graben of the Mariana Trough in a water depth of 3819 meters. A basement section of 80 meters of basalts interbedded with sediments was recovered from Hole 454A. The oldest sediments are between 1.2 and $1.6 \mathrm{~m}$.y. old. Five lithological units and three paleomagnetic units were distinguished by the shipboard party. The basalts are all considerably more vesicular than mid-ocean ridge basalts (MORB) erupted in similar water depths (e.g., Moore and Schilling, 1973).

The geochemical units correspond with the paleomagnetic units (Fig. 4). The basalts of Geochemical Unit 1 are olivine phyric (about $10 \%$ phenocrysts) with chrome spinel microphenocrysts and contain up to 14 weight percent $\mathrm{MgO}$. The basalts in Geochemical Unit 2 are sparsely plagioclase, olivine, and clinopyroxene phyric, and those in Unit 3 are sparsely olivine phyric (up to $7 \%$ phenocrysts) with associated chrome spinel. The major element chemistry of the basalts (Table 3 ) is similar to normal or N-type MORB with high $\mathrm{CaO}$ (about 11 wt. \%), but low $\mathrm{K}_{2} \mathrm{O}$ and $\mathrm{TiO}_{2}$ (about 1 wt. \%). However, these basalts have higher $\mathrm{Sr}, \mathrm{Ba}, \mathrm{Th}$, and light REE contents relative to $\mathrm{Zr}, \mathrm{Ti}, \mathrm{Y}$, and the heavy REE than N-type MORB. In addition they also display a depletion of $\mathrm{Ta}$ relative to $\mathrm{Th}$ and $\mathrm{La}$. These trace element characteristics are similar to those observed in island arc magmas. Their high vesicularity also indicates a volatile rich magma (Garcia et al., 1979).

\section{Site 456 \\ $\left(17^{\circ} 54.7^{\prime} \mathrm{N}, 145^{\circ} 10.8^{\prime} \mathrm{E}\right)$}

This site was located $37 \mathrm{~km}$ east of the central graben of the Mariana Trough in a water depth of 3590 meters. 
The sediment above the basement had an age of about 1.8 m.y. In two holes, short basement sections (Hole 456 about 35 meters; Hole $456 \mathrm{~A}$ about 40 meters) of altered pillow basalt were recovered. The top of the basement sections in both holes has suffered intense hydrothermal alteration, under reducing conditions, with abundant pyrite mineralization and quartz veining. Toward the bottom of the basement sections in both holes, the basalts are only slightly to moderately altered, under oxidizing conditions, and contain fresh glass.

Two lithological units in Hole 456 and four lithological units in Hole $456 \mathrm{~A}$ were distinguished by the shipboard party. Unit 1 of both holes includes intensely altered pillow basalts which are aphýric or sparsely plagioclase phyric (about 1 or $2 \%$ phenocrysts). Unit $456 \mathrm{~A}-2^{5}$ is a coarsely plagioclase phyric basalt (greater than $20 \%$ resorbed phenocrysts) with pseudomorphs of rare olivine phenocrysts. Unit 456A-3 is a highly vesicular (up to $30 \%$ vesicles of 0.2 to $2 \mathrm{~mm}$ diameter), aphyric basalt with up to 3 percent olivine microphenocrysts. Unit 456A-4 varies from aphyric to sparsely plagioclase phyric basalts with rare clinopyroxene phenocrysts. Unit 456-3 is also aphyric and similar to Units 456A-3 and 4 . Units $456-3$ and $456 \mathrm{~A}-4$ are vesicular but less so than Unit 456A-3. The shipboard party have grouped Units 456A-3 and 456-3 together, but from the geochemical data it is apparent that basalts corresponding to Units 456A-2 and 3 are not present in Hole 456 and that Unit $456-3$ can probably be equated with Unit 456A-4 (see below and Fig. 5). Unit 456A-5 is petrographically similar to Unit 456A-3, although less vesicular, but chemically it is indistinguishable from Unit $456 \mathrm{~A}-4$.

Most of the basalts from both holes have major and trace element chemistry (Table 4) similar to N-type MORB, although with slightly higher $\mathrm{Sr}$ and $\mathrm{Ba}$ contents. However, the porphyritic Unit $456 \mathrm{~A}-2$ and the relatively Mg-poor Unit 456A-3 are significantly enriched in $\mathrm{Th}, \mathrm{Sr}, \mathrm{Ba}, \mathrm{K}$, and light $\mathrm{REE}$ relative to $\mathrm{Zr}, \mathrm{Ti}$, $\mathrm{Y}$, and the heavy REE when compared to N-type MORB. They also show a depletion of Ta relative to Th and $\mathrm{La}$ (Table 11). The basalts from these units therefore have trace element characteristics that are quite similar to island arc tholeiites.

\section{Site 457 \\ $\left(17^{\circ} 49.99^{\prime} \mathrm{N}, 145^{\circ} 49.02^{\prime} \mathrm{E}\right)$}

This site was located on the active Mariana arc in a water depth of 2630 meters. The hole penetrates only coarse sand and volcaniclastic breccias. We have analyzed one sample of a basaltic andesite clast from the breccia (Tables 5 and 11). There are no petrographic data available for the analyzed sample, but the crystalvitric tuff clasts with which it is associated in the breccia included glass fragments with sparse euhedral plagioclase, clinopyroxene, and amphibole phenocrysts. The analysis indicates that the sample has calc-alkaline af-

\footnotetext{
${ }^{5}$ Denotes lithologic unit, not to be confused with Core 456A-2.
}

finities with high $\mathrm{Th}, \mathrm{K}, \mathrm{Ba}, \mathrm{Sr}$, and light $\mathrm{REE}$ relative to $\mathrm{Zr}, \mathrm{Ti}, \mathrm{Y}$, and heavy REE contents.

\section{Inter-Site Relationships of Basement Chemistry}

The chemical data for the samples from Sites 454, 456 , and 457 have been plotted on a series of major and trace element variation diagrams (Figs. 6 through 13). The main feature of the chemical variations in the basic lavas from these sites is the systematic gradation in chemistry from basalts similar to N-type MORB to basalts with calc-alkaline affinities. At Sites 454 and 456, which have penetrated inter-arc basin crust, both basalt types are found interlayered within a single hole. Geochemical Units $454 \mathrm{~A}-1,454 \mathrm{~A}-2,456 \mathrm{~A}-2,456 \AA-3$, and 457 have calc-alkaline affinities, whereas Geochemical Units 454A-3, 456-1 (and 456A-1?-extensive hydrothermal alteration), and $456 \mathrm{~A}-4$ have compositions quite similar to N-type MORB.

Figure 6 shows that for the same $\mathrm{MgO}$ contents the MORB-like lavas have higher $\mathrm{Zr}$ and $\mathrm{Ti}$ but lower $\mathrm{Sr}$ than the units with calc-alkaline affinities. Biaxial plots of HYG elements (Figs. 7 and 8) confirm that the different magma types cannot be related by simple crystal fractionation processes. On such diagrams, magmas related by crystal fractionation should conform to straightline trends passing through the origin (Weaver et al., 1972; Treuil and Varet, 1973). On the contrary, the Mariana Trough basalts can be seen to follow several diverse trends.

The occurrence of lavas with MORB-like and arc-like characteristics interbedded in the crust of the Mariana Trough at two localities has important implications for the magmatic processes controlling the formation of this inter-arc basin. One possibility is that the two basalt types were co-magmatic. If so, such small scale lithostratigraphic variations indicate that eruptions are related to small, short-lived magma reservoirs. This has also been proposed for the slow-spreading Mid-Atlantic Ridge to explain similar interlayering of geochemically different basalt types which cannot be related by crystal fractionation processes (Wood et al., 1979a). Rocks previously dredged from the Mariana Trough also show a range of compositions (Hart et al., 1972), and, although some are similar to MORB, others have some geochemical affinities with arc magma types. Hart et al. (1972) distinguished those lavas from arc magmas on the basis of their low ${ }^{87} \mathrm{Sr} /{ }^{86} \mathrm{Sr}$ (less than 0.7030 ) and $\mathrm{K} / \mathrm{Ba}$ (less than 85 ) ratios, despite them having $\mathrm{Ba}(25-50 \mathrm{ppm}), \mathrm{K}$ (2350-4200 ppm), and $\mathrm{Sr}(155-208)$ contents, considerably higher than average MORB $(\mathrm{Ba} \sim 12 \mathrm{ppm}, \mathrm{K} \sim$ $1060 \mathrm{ppm}, \mathrm{Sr} \sim 124 \mathrm{ppm}-$ Wood, 1979; Sun et al., 1979). Also, the dredged basalts studied by Hart et al. (1972) have flat or slightly light-REE-enriched, chondrite-normalized REE ratios.

Wood et al. (1980a) have recently noted that the abundance of $\mathrm{Ba}$ relative to $\mathrm{K}, \mathrm{Th}, \mathrm{U}$, and $\mathrm{Rb}$ varies significantly in arc basalts from the West Pacific, with the Japanese arcs (Wood et al., 1980a) being most enriched in Ba. Hart et al. (1972) suggest that island arc tholeiites have $\mathrm{K} / \mathrm{Ba}$ ratios invariably less than 30 to 40 , based on the work of Philpotts et al. (1971) on Japanese 
D. A. WOOD ET AL.

Table 1. Major and trace element analyses of igneous rocks from Hole 453.

\begin{tabular}{|c|c|c|c|c|c|c|c|c|c|c|c|c|}
\hline $\begin{array}{c}\text { Sample } \\
\text { (interval } \\
\text { (in cm) }\end{array}$ & $\begin{array}{c}42-1 \\
16-18\end{array}$ & $\begin{array}{c}47-1, \\
99-101\end{array}$ & $\begin{array}{c}49-1 \\
56-58\end{array}$ & $\begin{array}{l}49-3 \\
52-54\end{array}$ & $\begin{array}{c}50-2 \\
37-39\end{array}$ & $\begin{array}{c}52-1 \\
96-98\end{array}$ & $\begin{array}{l}52-2 \\
94-96\end{array}$ & $\begin{array}{c}53-3 \\
0-2\end{array}$ & $\begin{array}{c}54-1, \\
40-42\end{array}$ & $\begin{array}{l}54-2, \\
84-86\end{array}$ & $\begin{array}{c}54-3 \\
6\end{array}$ & $\begin{array}{c}55-2, \\
14-16\end{array}$ \\
\hline $\mathrm{SiO}_{2}$ & 56.0 & 50.2 & 46.2 & 55.9 & 45.1 & 51.0 & 46.0 & 45.3 & 46.6 & 52.4 & 51.4 & 45.9 \\
\hline $\mathrm{TiO}_{2}$ & 0.82 & 0.94 & 0.07 & 0.74 & 0.21 & 1.00 & 0.18 & 0.17 & 0.21 & 0.81 & 1.00 & 1.08 \\
\hline $\mathrm{Al}_{2} \mathrm{O}_{3}$ & 13.4 & 11.1 & 23.8 & 17.1 & 14.0 & 15.7 & 19.3 & 19.1 & 21.3 & 16.1 & 15.1 & 14.7 \\
\hline $\mathrm{tFe}_{2} \mathrm{O}_{3}$ & 9.98 & 13.47 & 5.76 & 9.57 & 8.08 & 11.37 & 8.93 & 7.04 & 6.27 & 10.84 & 12.25 & 14.48 \\
\hline $\mathrm{MnO}$ & 0.20 & 0.19 & 0.07 & 0.15 & 0.11 & 0.15 & 0.18 & 0.10 & 0.09 & 0.18 & 0.4 & 0.32 \\
\hline $\mathrm{MgO}$ & 5.72 & 10.10 & 7.18 & 4.71 & 15.10 & 5.71 & 10.71 & 10.37 & 7.88 & 7.04 & 6.03 & 8.57 \\
\hline $\mathrm{CaO}$ & 5.97 & 1.30 & 15.21 & 7.82 & 16.12 & 9.86 & 9.52 & 17.17 & 15.97 & 5.83 & 9.32 & 5.79 \\
\hline $\mathrm{Na}_{2} \mathrm{O}$ & 3.13 & 2.53 & 0.75 & 3.51 & 0.38 & 2.93 & 0.87 & 0.43 & 1.18 & 3.91 & 2.23 & 3.30 \\
\hline $\mathrm{K}_{2} \mathrm{O}$ & 0.71 & 3.69 & 0.54 & 0.82 & 0.18 & 0.56 & 2.43 & 0.36 & 0.59 & 1.66 & 1.18 & 0.58 \\
\hline $\mathrm{P}_{2} \mathrm{O}_{5}$ & 0.10 & 0.25 & 0.00 & 0.17 & 0.00 & 0.31 & 0.00 & 0.00 & 0.00 & 0.18 & 0.13 & 0.16 \\
\hline Total & 95.99 & 93.75 & 99.60 & 100.55 & 99.28 & 98.67 & 98.09 & 100.08 & 100.10 & 98.99 & 98.87 & 94.84 \\
\hline $\mathrm{Ni}$ & 9 & 15 & 24 & 4 & 58 & 11 & 36 & 39 & 20 & 5 & 6 & 3 \\
\hline $\mathrm{Cr}$ & 36 & 27 & 25 & 8 & 304 & 16 & 146 & 122 & 123 & 13 & 21 & 13 \\
\hline $\mathrm{Zn}$ & 83 & 86 & 8 & 43 & 21 & 34 & 58 & 20 & 27 & 48 & 75 & 92 \\
\hline Ga & 20 & 18 & 15 & 20 & 11 & 17 & 11 & 12 & 14 & 17 & 18 & 20 \\
\hline $\mathrm{Rb}$ & 8 & 35 & 5 & 8 & $<1$ & 9 & 25 & 5 & 4 & 18 & 17 & 7 \\
\hline $\mathrm{Sr}$ & 187 & 72 & 418 & 384 & 204 & 511 & 240 & 314 & 398 & 338 & 429 & 322 \\
\hline $\mathrm{Y}$ & 29 & 46 & 3 & 25 & 3 & 25 & $<1$ & 1 & 2 & 25 & 21 & 23 \\
\hline $\mathrm{Zr}$ & 91 & 52 & 9 & 41 & 5 & 82 & 6 & 8 & 9 & 65 & 55 & 56 \\
\hline $\mathrm{Nb}$ & 1 & 1 & $<1$ & $<1$ & $<1$ & $<1$ & $<1$ & $<1$ & $<1$ & $<1$ & $<1$ & $<1$ \\
\hline $\mathrm{Ba}$ & 266 & 288 & 126 & 231 & 40 & 148 & 1018 & 72 & 297 & 429 & 326 & 144 \\
\hline $\mathrm{La}$ & 8 & 15 & 3 & 9 & 9 & 20 & 7 & 2 & 2 & 9 & 12 & 11 \\
\hline $\mathrm{Ce}$ & 15 & 21 & 1 & 11 & 4 & 27 & 3 & 5 & $<1$ & 19 & 19 & 17 \\
\hline $\mathrm{Nd}$ & 11 & 16 & 3 & 9 & 2 & 16 & 3 & 3 & 1 & 14 & 12 & 11 \\
\hline $\mathrm{Pb}$ & 6 & 11 & 3 & 5 & 6 & 8 & 2 & 1 & 3 & $<1$ & 7 & 1 \\
\hline Th & $<1$ & $<1$ & 1 & 2 & 1 & 4 & 1 & $<1$ & 2 & 3 & 5 & 2 \\
\hline $\mathrm{Zr} / \mathrm{Nb}$ & 91.0 & 52.0 & $>9.0$ & $>41.0$ & $>5.0$ & $>82.0$ & $>6.0$ & $>8.0$ & $>9.0$ & $>65.0$ & $>55.0$ & $>56.0$ \\
\hline $\mathrm{Ti} / \mathrm{Zr}$ & 54.0 & 108.0 & 45.0 & 108.0 & 253.0 & 73.0 & 176.0 & 131.0 & 143.0 & 74.0 & 109.0 & 116.0 \\
\hline $\mathrm{Y} / \mathrm{Zr}$ & 0.32 & 0.88 & 0.33 & 0.61 & 0.60 & 0.30 & $<0.17$ & 0.13 & 0.22 & 0.38 & 0.38 & 0.41 \\
\hline $\mathrm{Ce} / \mathrm{Zr}$ & 0.16 & 0.40 & 0.11 & 0.27 & 0.80 & 0.33 & 0.50 & 0.63 & $<0.11$ & 0.29 & 0.35 & 0.30 \\
\hline $\mathrm{Ba} / \mathrm{Zr}$ & 2.92 & 5.54 & 14.00 & 5.63 & 8.00 & 1.80 & 169.67 & 9.00 & 33.00 & 6.60 & 5.93 & 2.57 \\
\hline$(\mathrm{Ce} / \mathrm{Y})_{\mathrm{N}}$ & 1.27 & 1.12 & 0.82 & 1.08 & 3.27 & 2.65 & - & 12.28 & - & 1.87 & 2.22 & 1.82 \\
\hline $\mathrm{Fe} / \mathrm{Mg}$ & 2.02 & 1.55 & 0.93 & 2.36 & 0.62 & 2.31 & 0.97 & 0.79 & 0.92 & 1.79 & 2.36 & 1.96 \\
\hline $\mathrm{K} / \mathrm{Rb}$ & 740.0 & 875.0 & 903.0 & 852.0 & $>1461.0$ & 513.0 & 807.0 & 603.0 & 1233.0 & 766.0 & 576.0 & 688.0 \\
\hline $\mathrm{Ba} / \mathrm{Sr}$ & 1.42 & 4.00 & 0.30 & 0.60 & 0.20 & 0.29 & 4.24 & 0.23 & 0.75 & 1.27 & 0.76 & 0.45 \\
\hline Q & 10.5 & 0.0 & 0.0 & 5.5 & 0.0 & 0.7 & 0.0 & 0.0 & 0.0 & 0.0 & 2.1 & 0.0 \\
\hline Or & 4.4 & 23.3 & 3.2 & 4.8 & 1.0 & 3.3 & 14.6 & 2.1 & 3.5 & 9.9 & 7.1 & 3.6 \\
\hline $\mathrm{Ab}$ & 27.6 & 22.8 & 6.4 & 29.5 & 0.5 & 25.1 & 7.5 & 0.6 & 6.7 & 33.4 & 19.1 & 29.4 \\
\hline An & 21.2 & 5.2 & 60.2 & 28.4 & 36.2 & 28.5 & 42.4 & 49.2 & 51.0 & 21.8 & 28.1 & 24.8 \\
\hline $\mathrm{Ne}$ & 0.0 & 0.0 & 0.0 & 0.0 & 1.5 & 0.0 & 0.0 & 1.7 & 1.8 & 0.0 & 0.0 & 0.0 \\
\hline $\mathrm{Di}$ & 7.5 & 0.0 & 12.6 & 7.7 & 35.5 & 15.9 & 4.9 & 28.9 & 22.8 & 5.3 & 15.0 & 3.7 \\
\hline $\mathrm{Hy}$ & 24.2 & 31.1 & 6.0 & 19.8 & 0.0 & 20.8 & 3.8 & 0.0 & 0.0 & 13.6 & 23.3 & 9.2 \\
\hline Ol & 0.0 & 10.2 & 9.9 & 0.0 & 22.8 & 0.0 & 24.2 & 15.4 & 12.2 & 11.2 & 0.0 & 22.7 \\
\hline $\mathrm{Mt}$ & 1.8 & 2.5 & 1.0 & 1.7 & 1.4 & 2.0 & 1.6 & 1.2 & 1.1 & 1.9 & 2.2 & 2.7 \\
\hline Il & 1.6 & 1.9 & 0.1 & 1.4 & 0.4 & 1.9 & 0.3 & 0.3 & 0.4 & 1.5 & 1.9 & 2.2 \\
\hline Ap & 0.3 & 0.6 & 0.0 & 0.4 & 0.0 & 0.7 & 0.0 & 0.0 & 0.0 & 0.4 & 0.3 & 0.4 \\
\hline
\end{tabular}

Note: All CIPW norms calculated assuming an $\mathrm{Fe}_{2} \mathrm{O}_{3} / \mathrm{FeO}$ ratio of 0.15 .

lavas. However, island arc tholeiites recently recovered from DSDP Site 448 have $\mathrm{K} / \mathrm{Ba}$ ratios greater than 90 (Mattey et al., 1980). We note also that the low-temperature sea-water alteration could significantly increase the $\mathrm{K} / \mathrm{Ba}$ ratios of the lavas. Thus, the high $\mathrm{K} / \mathrm{Ba}$ ratios of the dredged basalts do not necessarily distinguish them from arc magmas. The basalts recovered from the Leg 60 drill sites have suffered variable degrees of alteration, and consequently the $\mathrm{K} / \mathrm{Ba}$ ratios vary considerably. Nevertheless, the $\mathrm{K} / \mathrm{Ba}$ ratios of most samples from Units $457,454 \mathrm{~A}-1$, and $454 \mathrm{~A}-2$ are less than 50 , but in Unit $454 \mathrm{~A}-3 \mathrm{~K} / \mathrm{Ba}$ varies from 64 to 94 . The calc-alkaline arc lavas drilled at Site 451 (Mattey et al., 1980) have $\mathrm{K} / \mathrm{Ba}$ ratios less than 40.
In Figures 9 and 10, $\mathrm{Ni}$ versus $\mathrm{Zr}$ and $\mathrm{Cr}$ versus $\mathrm{Zr}$, the units which have calc-alkaline affinities and those MORB-like units follow distinct trends. This is mainly due to the different $\mathrm{Zr}$ contents of the different magma types. The plot of $\mathrm{Zr}$ versus $\mathrm{Ti}$ (Fig. 11) shows that most of the lavas have $\mathrm{Ti} / \mathrm{Zr}$ ratios between 75 and 100 , whilst $\mathrm{N}$-type MORB generally have $\mathrm{Ti} / \mathrm{Zr}$ ratios in the range 90 to 120 . Significantly, Units $456 \mathrm{~A}-3$ and 457 have $\mathrm{Ti} / \mathrm{Zr}$ ratios less than 90 . The main HYG element differences between the two magma types have been summarized in Figure 12. Here the HYG element abundances of three representative samples have been normalized to estimated primordial mantle abundances (Wood, 1979) and arranged in approximate order of in- 
Table 1. (Continued).

\begin{tabular}{|c|c|c|c|c|c|c|c|c|c|c|c|c|}
\hline $\begin{array}{l}55-3, \\
25-27\end{array}$ & $\begin{array}{l}55-3 \\
90-92\end{array}$ & $\begin{array}{c}55-4 \\
144-146\end{array}$ & $\begin{array}{l}56-2 \\
33-35\end{array}$ & $\begin{array}{l}56-2 \\
85-87\end{array}$ & $\begin{array}{l}57-1, \\
30-32\end{array}$ & $\begin{array}{l}57-3, \\
8-10\end{array}$ & $\begin{array}{c}57-4 \\
36-38\end{array}$ & $\begin{array}{c}57-4, \\
123-125\end{array}$ & $\begin{array}{c}58-1 \\
6-8\end{array}$ & $\begin{array}{l}59-1, \\
13-15\end{array}$ & $\begin{array}{l}59-1 \\
47-49\end{array}$ & $\begin{array}{c}63-1 \\
0-2\end{array}$ \\
\hline 41.8 & 44.6 & 43.7 & 42.6 & 48.0 & 48.3 & 42.4 & 43.0 & 42.6 & 43.7 & 70.5 & 61.0 & 48.0 \\
\hline 0.04 & 0.23 & 0.05 & 0.05 & 0.05 & 0.83 & 0.05 & 0.16 & 0.03 & 1.28 & 0.46 & 0.73 & 0.82 \\
\hline 21.7 & 19.0 & 27.6 & 24.7 & 23.0 & 15.2 & 24.7 & 17.9 & 29.1 & 14.1 & 12.1 & 12.8 & 13.9 \\
\hline 8.29 & 8.36 & 5.99 & 8.15 & 5.90 & 11.67 & 6.94 & 10.73 & 4.79 & 15.30 & 6.88 & 6.65 & 13.06 \\
\hline 0.11 & 0.10 & 0.09 & 0.14 & 0.09 & 0.17 & 0.09 & 0.12 & 0.06 & 0.39 & 0.36 & 0.11 & 0.26 \\
\hline 12.81 & 11.48 & 6.99 & 9.06 & 8.24 & 8.34 & 11.23 & 14.41 & 7.44 & 14.24 & 2.89 & 1.94 & 12.63 \\
\hline 12.82 & 16.92 & 12.82 & 11.69 & 9.76 & 13.47 & 14.34 & 11.94 & 15.26 & 1.02 & 0.66 & 8.80 & 2.66 \\
\hline 0.51 & 0.32 & 0.96 & 0.97 & 2.65 & 1.69 & 0.38 & 0.44 & 0.56 & 3.00 & 4.98 & 7.50 & 3.34 \\
\hline 0.29 & 0.07 & 1.20 & 0.73 & 1.34 & 0.21 & 0.16 & 0.09 & 0.53 & 0.05 & 0.24 & 0.03 & 0.21 \\
\hline 0.00 & 0.00 & 0.00 & 0.00 & 0.00 & 0.03 & 0.00 & 0.00 & 0.00 & 0.20 & 0.07 & 0.17 & 0.10 \\
\hline 98.32 & 101.09 & 99.38 & 98.05 & 98.99 & 99.99 & 100.32 & 98.78 & 100.34 & 93.22 & 99.14 & 99.77 & 95.00 \\
\hline 58 & 46 & 17 & 41 & 22 & 13 & 51 & 77 & 32 & 9 & $<1$ & 7 & 10 \\
\hline 8 & 234 & 2 & $<1$ & 1 & 26 & 62 & 265 & $<1$ & 40 & $<1$ & 16 & 20 \\
\hline 31 & 25 & 28 & 50 & 26 & 63 & 19 & 42 & 16 & 127 & 300 & 19 & 67 \\
\hline 13 & 14 & 17 & 16 & 14 & 18 & 12 & 13 & 16 & 20 & 12 & 6 & 17 \\
\hline 3 & $<1$ & 11 & 7 & 14 & 2 & 1 & 1 & 4 & $<1$ & 2 & $<1$ & 3 \\
\hline 413 & 311 & 456 & 418 & 354 & 387 & 427 & 364 & 523 & 222 & 108 & 124 & 275 \\
\hline$<1$ & 1 & $<1$ & $<1$ & $<1$ & 12 & $<1$ & 1 & $<1$ & 32 & 30 & 13 & 16 \\
\hline 7 & 10 & 7 & 7 & 10 & 21 & 6 & 10 & 10 & 77 & 84 & 44 & 45 \\
\hline$<1$ & $<1$ & $<1$ & $<1$ & $<1$ & $<1$ & $<1$ & $<1$ & $<1$ & $<1$ & $<1$ & $<1$ & $<1$ \\
\hline 68 & 13 & 547 & 301 & 409 & 80 & 42 & 58 & 148 & 112 & 104 & 32 & 118 \\
\hline 9 & 8 & 4 & 2 & 2 & 6 & 8 & 11 & 3 & 17 & 7 & 4 & 6 \\
\hline 4 & $<1$ & 4 & 6 & $<1$ & 6 & 3 & 3 & 3 & 19 & 12 & 15 & 15 \\
\hline 2 & 1 & 3 & 3 & 1 & 5 & 1 & 3 & 1 & 14 & 8 & 8 & 8 \\
\hline 3 & $<1$ & 2 & 1 & 3 & 5 & 2 & 5 & 2 & 6 & 4 & 4 & 3 \\
\hline 2 & $<1$ & $<1$ & $<1$ & $<1$ & $<1$ & $<1$ & $<1$ & $<1$ & $<1$ & $<1$ & 2 & 5 \\
\hline$>7.0$ & $>10.0$ & $>7.0$ & $>7.0$ & $>10.0$ & $>21.0$ & $>6.0$ & $>10.0$ & $>10.0$ & $>77.0$ & $>84.0$ & $>44.0$ & $>45.0$ \\
\hline 35.0 & 137.0 & 44.0 & 39.0 & 31.0 & 234.0 & 55.0 & 95.0 & 20.0 & 100.0 & 33.0 & 99.0 & 110.0 \\
\hline$<0.14$ & 0.10 & $<0.14$ & $<0.14$ & $<0.10$ & 0.57 & $<0.17$ & 0.10 & $<0.10$ & 0.42 & 0.36 & 0.30 & 0.36 \\
\hline 0.57 & $<0.10$ & 0.57 & 0.86 & $<0.10$ & 0.29 & 0.50 & 0.30 & 0.30 & 0.25 & 0.14 & 0.34 & 0.33 \\
\hline 9.71 & 1.30 & 78.14 & 43.00 & 40.90 & 3.81 & 7.00 & 5.80 & 14.80 & $1: 45$ & 1.24 & 0.73 & 2.62 \\
\hline- & - & - & - & - & 1.23 & - & 7.37 & - & 1.46 & 0.98 & 2.83 & 2.30 \\
\hline 0.75 & 0.84 & 0.99 & 1.04 & 0.83 & 1.62 & 0.72 & 0.86 & 0.75 & 1.25 & 2.76 & 3.98 & 1.20 \\
\hline 808.0 & $>623.0$ & 906.0 & 869.0 & 795.0 & 884.0 & 1353.0 & 780.0 & 1100.0 & $>390.0$ & 988.0 & $>282.0$ & 592.0 \\
\hline 0.16 & 0.04 & 1.20 & 0.72 & 1.16 & 0.21 & 0.10 & 0.16 & 0.28 & 0.50 & 0.96 & 0.26 & 0.43 \\
\hline 0.0 & 0.0 & 0.0 & 0.0 & 0.0 & 0.0 & 0.0 & 0.0 & 0.0 & 0.0 & 31.2 & 1.3 & 0.0 \\
\hline 1.8 & 0.3 & 7.1 & 4.4 & 8.0 & 1.3 & 1.0 & 0.6 & 2.1 & 0.3 & 1.4 & 0.2 & 1.3 \\
\hline 1.8 & 0.0 & 5.6 & 7.7 & 19.7 & 14.3 & 0.9 & 3.8 & 0.0 & 27.2 & 42.5 & 63.6 & 29.7 \\
\hline 56.9 & 49.6 & 64.2 & 59.3 & 47.4 & 33.4 & 64.9 & 47.1 & 75.0 & 4.1 & 2.9 & 1.2 & 13.3 \\
\hline 1.4 & 1.5 & 1.4 & 0.4 & 1.6 & 0.0 & 1.2 & 0.0 & 2.5 & 0.0 & 0.0 & 0.0 & 0.0 \\
\hline 6.3 & 27.0 & 0.0 & 0.0 & 1.4 & 27.4 & 4.9 & 10.4 & 0.5 & 0.0 & 0.0 & 25.6 & 0.0 \\
\hline 0.0 & 0.0 & 0.0 & 0.0 & 0.0 & 10.6 & 0.0 & 6.4 & 0.0 & 36.6 & 16.6 & 0.0 & 34.6 \\
\hline 29.5 & 19.0 & 18.6 & 25.0 & 20.3 & 8.4 & 25.1 & 28.5 & 17.8 & 16.1 & 0.0 & 0.0 & 11.7 \\
\hline 1.5 & 1.4 & 1.0 & 1.4 & 1.0 & 2.0 & 1.2 & 1.9 & 0.8 & 2.9 & 1.2 & 1.2 & 2.4 \\
\hline 0.1 & 0.4 & 0.1 & 0.1 & 0.1 & 1.6 & 0.1 & 0.3 & 0.1 & 2.6 & 0.9 & 1.4 & 1.6 \\
\hline 0.0 & 0.0 & 0.0 & 0.0 & 0.0 & 0.1 & 0.0 & 0.0 & 0.0 & 0.5 & 0.2 & 0.4 & 0.3 \\
\hline
\end{tabular}

compatibility with the major mantle mineral phases. The enrichment of $\mathrm{Cs}, \mathrm{Rb}, \mathrm{Ra}, \mathrm{Th}, \mathrm{U}$, and $\mathrm{K}$ relative to $\mathrm{Hf}, \mathrm{Zr}, \mathrm{Ti}, \mathrm{Y}$, and the heavy REE and the marked depletion in $\mathrm{Ta}$ and $\mathrm{Nb}$ for the calc-alkaline magma types clearly distinguish them from MORB-like lavas.

In Figure 13 the lavas from Sites 454,456 , and 457 have been plotted in the $\mathrm{Th}-\mathrm{Hf} / 3-\mathrm{Ta}$ discrimination diagram (Wood et al., 1979b; Wood, 1980) with the fields of N-type MORB (A), E-type MORB (B), within plate lava series (C), and active plate margin lava series (D) distinguished. The field of active margin lava series (D) has been enlarged relative to that originally proposed (Wood et al., 1979b, fig. 4) to include additional analyses of arc tholeiites from Japan and DSDP Site 448 as well as the fore-arc lavas from DSDP Sites 458 through 461 (described later). All the basalts from Site 456 except Unit 456A-3 plot within the field of N-type MORB, and Unit 454A-3 plots between fields $A$ and $D$ (Fig. 13). Units 456A-3, 454A-1, 454A-2, and 457 plot in field $D$ as expected.

Interestingly, the Site 454 lavas plot along a trend in Figure 13 between $\mathrm{N}$-type MORB and calc-alkaline magma types. We interpret this as a mixing line. There seem to be two possible explanations for this mixing relationship: (1) the two magma types were comagmatic in the crust of the Mariana Trough, being derived from small, short-lived magma chambers, in which mixing between the magma types could occur in some instances. Mixing due to episodic injection of magma into a small, sub-crustal reservoir is a common process at the 


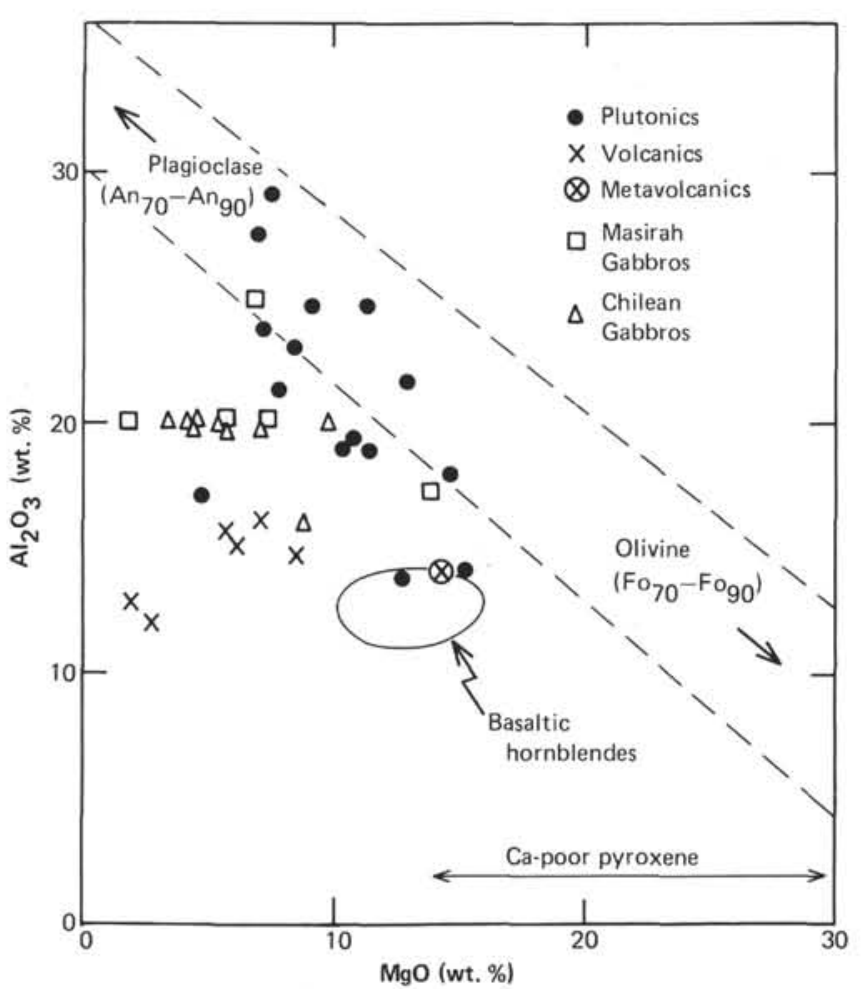

Figure 2. $\mathrm{Al}_{2} \mathrm{O}_{3}$ versus $\mathrm{MgO}$ for igneous rocks from Site 453, showing that most of the plutonic rocks contain cumulate plagioclase and a ferromagnesian mineral.

Mid-Atlantic Ridge (Rhodes et al., 1979). Resorbed phenocrysts are present in the porphyritic Unit 456A-2 and could support a magma mixing hypothesis. The presently available data for petrography and mineralogy of the basalts from this site do not provide additional evidence of magma mixing (e.g., resorbed phenocrysts out of equilibrium with the bulk rock; differences in the composition of glass inclusions in the phenocrysts and bulk rock), but a more detailed study would clearly be worthwhile. (2) An N-type MORB magma type could have assimilated small but variable amounts of arc-derived sediments. Basalts from Sites 454 and 456 are associated with arc-derived vitric tuffs. One basalt at Site 456 actually contains a large recrystallized tuffaceous xenolith (see Site 456 summary, this volume). Low seismic velocities at Site 454 suggest that sediments may be interbedded with basalts for several hundred meters and some of the more massive basalts could be intrusive. This would provide a suitable environment for sediment assimilation. The fact that from the same cooling unit some samples have trace element characteristics of arc tholeiites, and other samples have trace element characteristics of N-type MORB, tends to support a heterogeneous assimilation process rather than a more homogeneous magma mixing process. Both processes could explain the lower ${ }^{87} \mathrm{Sr} /{ }^{86} \mathrm{Sr}$ and higher $\mathrm{K} / \mathrm{Ba}$ ratios of these lavas (e.g., dredge samples of Hart et al., 1972) than most calc-alkaline basalts.

Magma mixing and/or sediment assimilation processes may be important in the initial stages of opening of an inter-arc basin and could explain the chemical

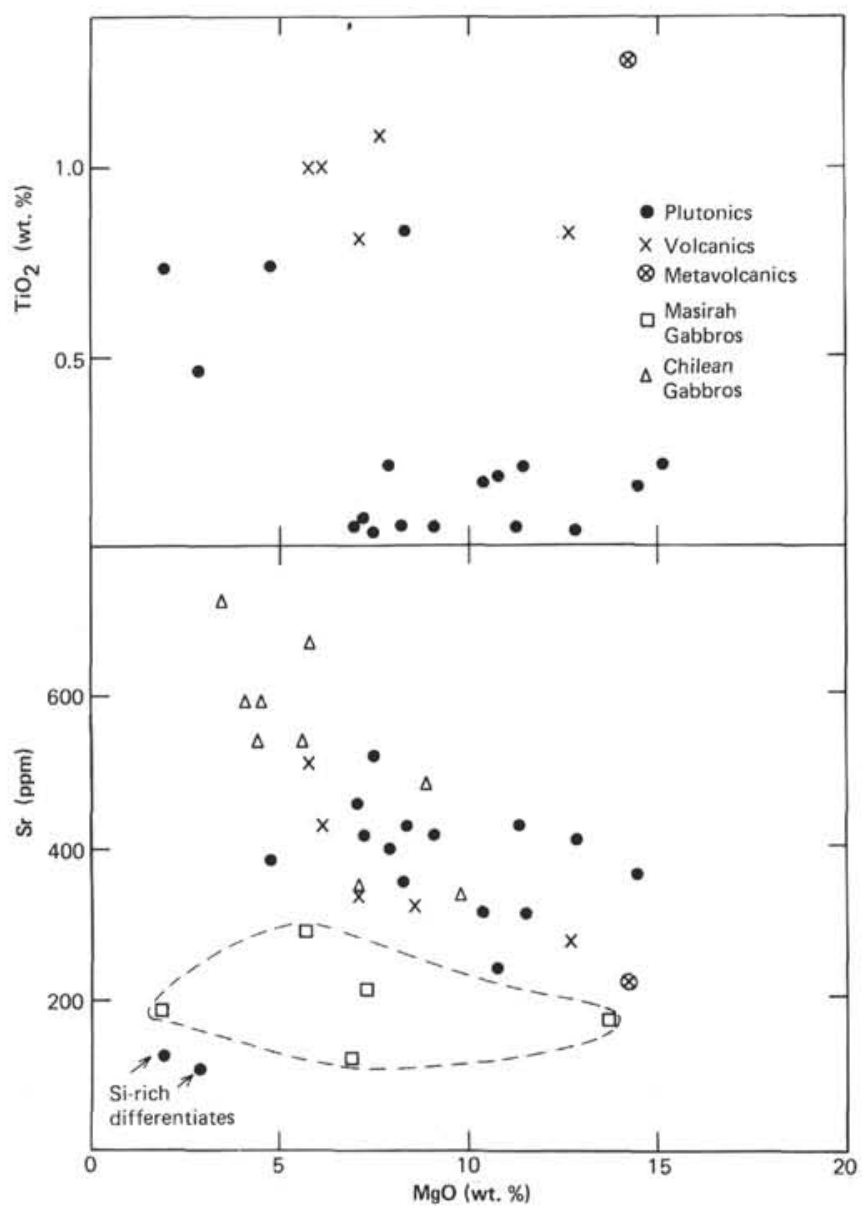

Figure 3. $\mathrm{TiO}_{2}$ and $\mathrm{Sr}$ versus $\mathrm{MgO}$ for igneous rocks from Site 453. Gabbros from the Masirah Ophiolite, Oman (Abbotts, 1979), also plagioclase cumulates (cf. Table 2), considered to represent the cumulate layer of oceanic crust, have lower $\mathrm{Sr}$ than the Site 453 rocks.

variation in basalts dredged from several such basins, which seem to have compositions related to both N-type MORB and arc magma types, but cannot be classed as one or the other. For example, those from the Lau Basin (Gill, 1976, Hawkins, 1976), the East Scotia Sea (Saunders and Tarney, 1979; Hawkesworth et al., 1978), and the Mariana Trough (Hart et al., 1972; this study). Some basalts from those basins have affinities with arc magma types, sharing with them higher $\mathrm{K}, \mathrm{Rb}, \mathrm{Ba}, \mathrm{Th}$, $\mathrm{Sr}$, and ${ }^{87} \mathrm{Sr}$, and lower $\mathrm{Ti}, \mathrm{Zr}, \mathrm{Hf}, \mathrm{Ta}$, and $\mathrm{Nb}$ relative to $\mathrm{N}$-type MORB. In contrast, basalts recovered from the broader, more developed marginal basins of the West Pacific-i.e., the Shikoku, West Philippine and Parece Vela Basins-show no clear chemical affinities with destructive margin magma types (Marsh et al., 1980; Mattey et al., 1980; Wood et al., 1980a, 1980b). Tarney et al. (1977) noted similar relationships in the marginal basins of the Scotia arc region. This may be due to the progressive decrease in arc magmatic activity or arc-derived volcaniclastic sediments in the basins as they become more developed. If so, it has important implications for the type of marginal basins sampled by ophiolites. For example, the Late Cretaceous Mediter- 
Table 2. Major and trace element XRF analyses of basic plutonic rocks from different tectonic environments.

\begin{tabular}{|c|c|c|c|c|c|c|c|c|c|c|c|c|c|c|}
\hline \multirow{2}{*}{$\begin{array}{l}\text { Sample } \\
\text { Number }\end{array}$} & \multicolumn{9}{|c|}{$\begin{array}{l}\text { Gabbros from the Chilean Cordillera } \\
\text { (Wells, 1978; Marsh, 1977) }\end{array}$} & \multicolumn{5}{|c|}{$\begin{array}{l}\text { Gabbros from the Masirah } \\
\text { Ophiolite, Oman (Abbotts, 1979) }\end{array}$} \\
\hline & C378 & C 379 & C387 & C389 & C397 & $\mathrm{C} 62$ & $\mathrm{Cl} 184$ & C71 & $\mathrm{C} 117$ & $\mathrm{X} 288$ & MA65 & MA205 & MA164 & MA417 \\
\hline \multicolumn{15}{|c|}{ Major Element Oxides (wt. $\%$ ) } \\
\hline $\mathrm{SiO}_{2}$ & 50.5 & 49.5 & 46.5 & 51.5 & 49.8 & 46.9 & 46.5 & 55.4 & 50.0 & 42.9 & 46.4 & 49.1 & 50.4 & 59.0 \\
\hline $\mathrm{TiO}_{2}$ & 0.68 & 1.61 & 0.80 & 1.15 & 0.22 & 0.16 & 0.79 & 0.88 & 0.53 & 0.07 & 0.18 & 0.25 & 0.45 & 0.55 \\
\hline $\mathrm{Al}_{2} \mathrm{O}_{3}$ & 19.9 & 20.0 & 21.4 & 18.6 & 16.1 & 19.1 & 18.4 & 17.4 & 20.4 & 24.7 & 17.2 & 20.9 & 20.2 & 18.8 \\
\hline $\mathrm{tFe}_{2} \mathrm{O}_{3}$ & 9.01 & 9.57 & 8.89 & 9.82 & 8.10 & 6.44 & 10.2 & 7.52 & 3.30 & 1.08 & 4.87 & 4.29 & 4.05 & 2.87 \\
\hline $\mathrm{MnO}$ & 0.14 & 0.18 & 0.11 & 0.14 & 0.13 & 0.13 & 0.17 & 0.13 & 0.11 & 0.02 & n.d. & 0.00 & 0.07 & 0.00 \\
\hline $\mathrm{MgO}$ & 4.05 & 3.43 & 4.53 & 4.40 & 8.86 & 9.82 & 7.05 & 5.74 & 5.60 & 6.85 & 13.89 & 7.24 & 5.68 & 1.80 \\
\hline $\mathrm{CaO}$ & 11.27 & 11.12 & 13.97 & 10.20 & 13.33 & 13.90 & 12.7 & 9.14 & 16.3 & 22.22 & 13.62 & 11.14 & 12.45 & 4.04 \\
\hline $\mathrm{Na}_{2} \mathrm{O}$ & 3.56 & 3.62 & 2.71 & 3.43 & 1.17 & 1.11 & 1.45 & 3.76 & 2.15 & 0.49 & 1.61 & 3.89 & 3.80 & 9.97 \\
\hline $\mathrm{K}_{2} \mathrm{O}$ & 0.50 & 0.23 & 0.09 & 0.41 & 0.12 & 0.09 & 0.45 & 0.15 & 0.08 & 0.03 & 0.09 & 0.28 & 0.08 & 0.05 \\
\hline $\mathrm{P}_{2} \mathrm{O}_{5}$ & 0.17 & 0.89 & 0.01 & 0.09 & 0.01 & 0.04 & 0.04 & 0.17 & 0.05 & 0.00 & 0.01 & 0.02 & 0.02 & 0.10 \\
\hline Total & 99.77 & 100.13 & 98.99 & 99.79 & 97.83 & 97.70 & 97.84 & 100.29 & 98.50 & 98.27 & 97.48 & 96.77 & 97.20 & 97.18 \\
\hline \multicolumn{15}{|c|}{ Trace Elements (ppm) } \\
\hline $\mathrm{Ni}$ & 68 & 18 & 41 & 58 & 174 & 259 & 24 & 56 & 35 & 91 & 237 & 70 & 40 & 5 \\
\hline $\mathrm{Cr}$ & 123 & 20 & 70 & 67 & 510 & 193 & 49 & 47 & 92 & 265 & 705 & 355 & 51 & $<1$ \\
\hline $\mathrm{Zn}$ & 60 & 108 & 59 & 65 & 63 & 56 & 55 & 22 & 23 & 15 & 24 & 9 & 20 & 4 \\
\hline $\mathrm{Ga}$ & 22 & 25 & 20 & 21 & 17 & 15 & 21 & 23 & 21 & 8 & 14 & 15 & 20 & 24 \\
\hline $\mathrm{Rb}$ & 1 & $<1$ & $<1$ & 5 & $<1$ & 1 & 21 & 4 & 1 & $<1$ & $<1$ & 2 & $<1$ & $<1$ \\
\hline Sr & 591 & 722 & 590 & 541 & 482 & 333 & 343 & 671 & 540 & 116 & 175 & 213 & 294 & 183 \\
\hline $\mathrm{Y}$ & 11 & 21 & $<1$ & 10 & 3 & 5 & 8 & 20 & 14 & $<1$ & 3 & 3 & 4 & 57 \\
\hline $\mathrm{Zr}$ & 76 & 77 & 35 & 80 & 30 & 34 & 37 & 190 & 54 & 8 & 8 & 19 & 28 & 711 \\
\hline $\mathrm{Nb}$ & $<1$ & 4 & 3 & 4 & $<1$ & 2 & 4 & 6 & 1 & $<1$ & $<1$ & 4 & 5 & 52 \\
\hline $\mathrm{Ba}$ & 179 & 152 & 59 & 141 & 33 & 43 & 59 & 175 & 53 & 7 & 16 & 41 & 33 & 87 \\
\hline $\mathrm{La}$ & 10 & 19 & 3 & 7 & 7 & 3 & 5 & 12 & 3 & 2 & $<1$ & $<1$ & 2 & 44 \\
\hline $\mathrm{Ce}$ & $<1$ & 30 & 4 & 6 & $<1$ & 11 & 11 & 26 & 14 & 3 & $<1$ & $<1$ & 4 & 88 \\
\hline $\mathrm{Pb}$ & 8 & 6 & $<1$ & 4 & $<1$ & 12 & 6 & $<1$ & 5 & $<1$ & $<1$ & $<1$ & $<1$ & $<1$ \\
\hline Th & $<1$ & 3 & $<1$ & $<1$ & $<1$ & $<1$ & $<1$ & 8 & $<1$ & n.d. & $<1$ & $<1$ & $<1$ & 17 \\
\hline
\end{tabular}

Notes: C378, C379, C387, C397 = plagioclase-clinopyroxene leucogabbros from Puerto Aisen, Southern Chile, C389 = plagioclase-clinopyroxene leucogabbro with minor primary hornblende from Puerto Aisen. C62, C184, C71, C117 = plagioclase-clinopyroxene leucogabbros from Atacama Province, Northern Chile.

X288 $=$ leuco-olivine gabbro (cumulus plagioclase $>$ olivine $=$ diopside).

MA65 = clinopyroxene gabbro (plagioclase $=$ diopside).

MA205 = clinopyroxene gabbro (screen to sheeted dykes).

MA164 = pegmatitic clinopyroxene gabbro.

MA417 = plagiogranite.

ranean ophiolites, which contain both MORB and arctype lavas in their crustal sequences (Pearce, in press), may represent crust formed in narrow, poorly developed inter-arc basins, such as the Mariana Trough or Lau Basin, rather than broad, well-developed back-arc basins.

For comparison, Tables 6 and 7 present the major and trace element compositions of calc-alkaline basalts and andesites dredged by P. Fryer and D. Hussong from a seamount in the northern part of the active Mariana Arc $\left(21^{\circ} 58^{\prime} \mathrm{N}, 143^{\circ} 28^{\prime} \mathrm{E}\right)$ following seismic activity suggesting a recent eruption in the area. These lavas are compositionally similar to the sub-aerially erupted lavas from the Mariana Islands (Dixon and Batiza, 1979; Stern, 1979; Chow et al., 1980) and the basalts from DSDP Sites 451,453 , and 457 . They have been plotted in the Th-Hf/3-Ta discrimination diagram (Fig. 13) and plot close to the other calc-alkaline lavas. However, they are significantly more evolved (i.e., low MgO: 2 to 4 wt. \%) than the drilled samples. This is consistent with the extensive near-surface crystal fractionation thought to prevail along the Mariana Arc (Stern, 1979).

\section{Mariana Fore-arc and Trench}

\section{Site 458 \\ $\left(17^{\circ} 51.85^{\prime} \mathrm{N}, 1^{146^{\circ}} 56.06^{\prime} \mathrm{E}\right)$}

This site was located on the southeast flank of a 40 mgal. positive gravity anomaly, $120 \mathrm{~km}$ east of the ac- tive Mariana arc, on the fore-arc midway between the arc and the trench in a water depth of 3447 meters. The sediments overlying the basement were approximately 35 m.y. old. Hole 458 penetrated 209 meters of basement rocks including glassy pillow lavas and massive flows (Fig. 14). The shipboard party divided the basement section into five lithological units. Units 1, 2, and 3 are petrographically similar but distinguished by their form: massive, coarse-grained lavas of Unit 2 separate the vesicular, glassy, fine-grained pillows of Units 1 and 3. These three units make up 123.5 meters of the cored interval. They are petrographically unusual in having endiopside and bronzite phenocrysts (with no olivine), and significant quantities of plagioclase are only present in the more holocrystalline samples. The shipboard party noted that the two pyroxene, glassy samples with no plagioclase resembled the boninites or $\mathrm{Mg}$-rich andesites previously reported from elsewhere on Western $\mathrm{Pa}$ cific fore-arcs, for example, the Bonin Islands (Kuroda and Shiraki, 1975; Kuroda et al., 1978; Shiraki et al., 1979), the Mariana Trench (Dietrich et al., 1978; Cameron et al., 1979), and Cape Vogel in southeast Papua New Guinea (Dallwitz, et al., 1966; Dallwitz, 1968).

Unit 4 consists of about 75 meters of vesicular, glassy to fine-grained, sparsely plagioclase and augite phyric pillow and massive lavas, relatively rich in $\mathrm{Fe}$-Ti oxides. The top 10 or so meters of this unit (Sections 41-1 and 41-2) are highly fractured and, although not distinguished petrographically, have a distinct chemistry from the rest of the unit (see below). We refer to this part as 


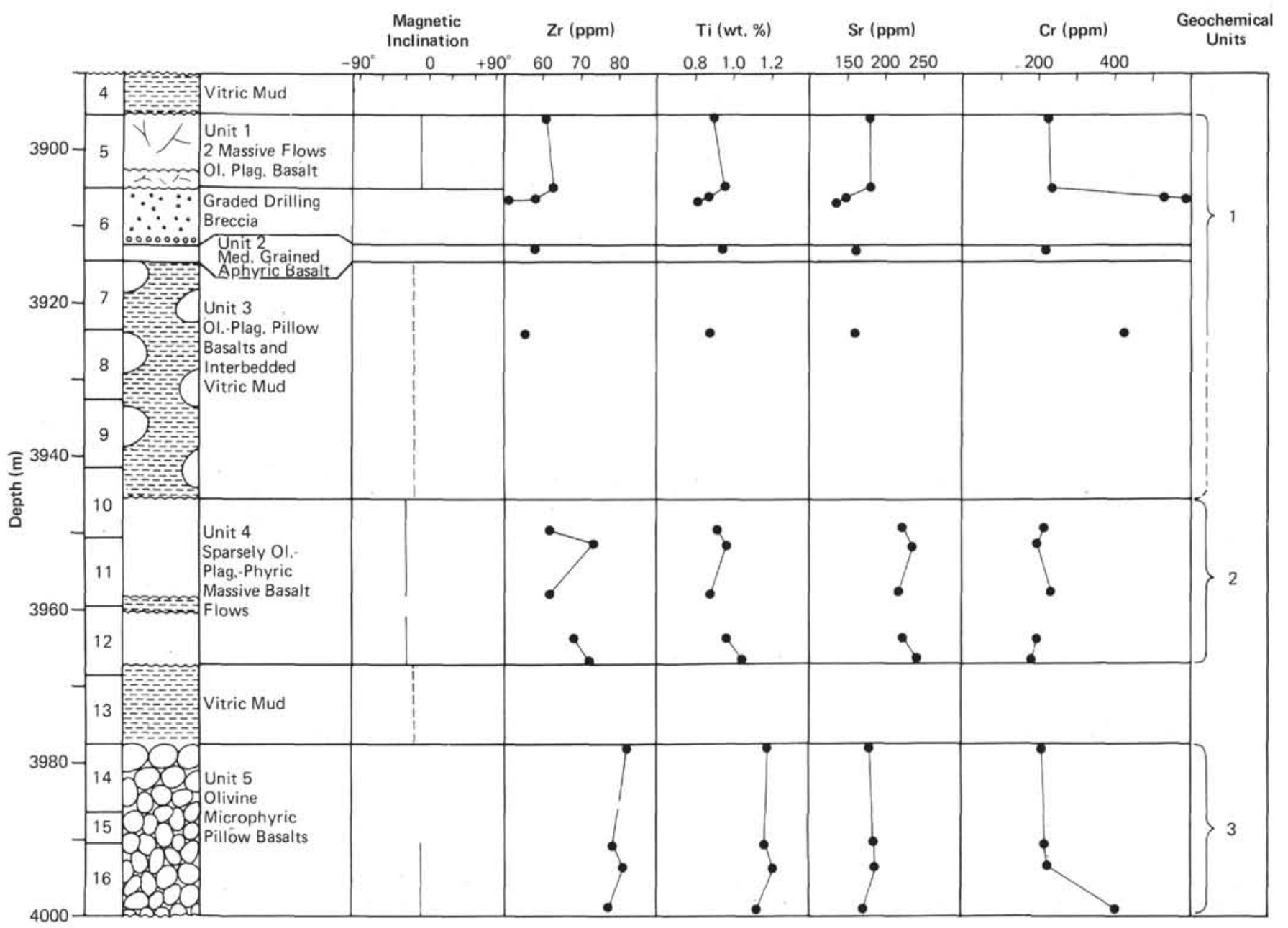

Figure 4. Geochemical and lithological stratigraphy of the basement sections of Hole 454A.

Unit $4 \mathrm{a}$. Another highly fractured zone $(\sim 0.5 \mathrm{~m})$ forms the lower part of Section 44-1 in Unit 4 and may be compositionally similar to Unit $4 \mathrm{a}$ but has not been sampled in this study. Unit 5 forms the lower 30 meters of the hole and consists of massive, fine-grained sparsely plagioclase and augite phyric lavas relatively rich in $\mathrm{Fe}-\mathrm{Ti}$ oxides. All the units have suffered low-temperature (zeolite facies) alteration. Most of the glassy matrices are recrystallized to clays, although a few fresh glassy pillow rinds are preserved.

The lavas from Units 1,2 , and 3 show coherent chemical compositions (Table 8 and Fig. 14) with high $\mathrm{SiO}_{2}$ (52 to 60 wt. \%), moderate to high $\mathrm{MgO}$ (5 to 10 wt. $\%$ ), high $\mathrm{K}_{2} \mathrm{O}$ (0.5 to 1.5 wt. \%), and very low $\mathrm{TiO}_{2}$ (about 0.3 wt. \%), $\mathrm{P}_{2} \mathrm{O}_{5}$ (about 0.03 wt. \%), $\mathrm{Zr}, \mathrm{Hf}$, REE, and Y contents. Although they are chemically related to boninites, these Site 458 rocks are more evolved: previously described boninites (e.g., Table 9) generally have $\mathrm{MgO}$ contents $>9$ percent, $\mathrm{Mg}$-numbers $>0.7, \mathrm{Ca}<8$ percent, $\mathrm{Al}_{2} \mathrm{O}_{3}<14$ percent, $\mathrm{Ni}>100$ $\mathrm{ppm}$, and $\mathrm{Cr}>600 \mathrm{ppm}$. Most of the Site 458 Units 1 , 2 , and 3 lavas have $\mathrm{MgO}<9$ percent, $\mathrm{Mg}$-numbers $<0.7, \mathrm{CaO}>8$ percent, $\mathrm{Al}_{2} \mathrm{O}_{3}>14$ percent, $\mathrm{Ni}<100$ $\mathrm{ppm}$, and $\mathrm{Cr}<300 \mathrm{ppm}$, and are probably best termed $\mathrm{Mg}$-rich andesites. Unit $458-4$ lavas are similar to those of the upper three units but with slightly higher abundances of $\mathrm{Fe}$ and the HYG elements and lower Mgnumbers and $\mathrm{Cr}$ and $\mathrm{Ni}$ contents. They are best termed andesites, but the relatively low abundances of the HYG elements in these lavas indicate that they are related to the $\mathrm{Mg}$-rich andesites and boninites described earlier.

Units $458-4 \mathrm{a}$ and $458-5$ are chemically different from the other Site 458 lavas and have the major element compositions of basaltic andesites. Both units have higher $\mathrm{TiO}_{2}$ (about 1.1 wt. \%) and HYG elements contents with low $\mathrm{CaO}(<7.5$ wt. \%) contents. Unit $458-4 \mathrm{a}$ has low $\mathrm{MgO}(<4$ wt. \%) and Unit 458-5 has very high $\mathrm{Fe}$ contents $\left(\Sigma \mathrm{Fe}_{2} \mathrm{O}_{3}\right.$ about 13.75 wt. \%) and could be termed a ferrobasalt. Units $458-4 a$ and $458-5$ both have compositions similar to those of primitive island-arc tholeiites.

\section{Site 459 \\ $\left(17^{\circ} \mathbf{5 1 . 7 5} \mathrm{N}, 147^{\circ} 18.09^{\prime} \mathrm{E}\right)$}

This site was located on the easternmost fore-arc basin, adjacent to the trench slope break in a water depth of 4120 meters. The basement was dated as prelate Eocene (74.5 m.y.) by the overlying sediments. Hole 459B penetrated 132.5 meters of basaltic basement divided into four lithologic units. The basalts are gener- 
Table 3. Major and trace element analyses of igneous rocks from Hole 454A.

\begin{tabular}{|c|c|c|c|c|c|c|c|c|c|c|c|c|c|c|c|}
\hline $\begin{array}{l}\text { Sample } \\
\text { (interval } \\
\text { in } \mathrm{cm} \text { ) }\end{array}$ & $\begin{array}{l}5-1, \\
2-4\end{array}$ & $\begin{array}{c}5-3 \\
106-108\end{array}$ & $\begin{array}{l}5-4 \\
15-17\end{array}$ & $\begin{array}{l}5-4 \\
16-18\end{array}$ & $\begin{array}{c}6-2 \\
102-104\end{array}$ & $\begin{array}{l}8-1 \\
2-4\end{array}$ & $\begin{array}{l}10-1 \\
81-83\end{array}$ & $\begin{array}{l}11-1, \\
40-42\end{array}$ & $\begin{array}{l}11-4, \\
71-73\end{array}$ & $\begin{array}{c}12-1 \\
100-102\end{array}$ & $\begin{array}{l}12-2 \\
26-28\end{array}$ & $\begin{array}{c}14-1 \\
2-4\end{array}$ & $\begin{array}{l}15-1 \\
13-15\end{array}$ & $\begin{array}{l}16-1, \\
32-35\end{array}$ & $\underset{111-113}{16-1}$ \\
\hline $\mathrm{SiO}_{2}$ & 49.3 & 49.9 & 49.3 & 49.3 & 50.3 & 49.3 & 50.9 & 51.5 & 52.2 & 51.8 & 51.6 & 51.5 & 50.8 & 52.0 & 50.2 \\
\hline $\mathrm{TiO}_{2}$ & 0.89 & 0.95 & 0.86 & 0.82 & 0.94 & 0.88 & 0.91 & 0.96 & 0.88 & 0.96 & 1.04 & 1.17 & 1.16 & 1.20 & 1,12 \\
\hline $\mathrm{Al}_{2} \overline{\mathrm{O}}_{3}$ & 14.7 & 14.9 & 14.4 & 14.1 & 14.9 & 14.2 & 14.8 & 15.2 & 14.9 & 13.9 & 15.2 & 15.7 & 15.6 & 16.0 & 14.5 \\
\hline $\mathrm{tFe}_{2} \mathrm{O}_{3}$ & 8.50 & 8.58 & 9.42 & 9.37 & 8.99 & 9.41 & 8.34 & 8.52 & 8.69 & 8.83 & 9.08 & 9.44 & 9.45 & 9.23 & 9.92 \\
\hline $\mathrm{MnO}$ & 0.17 & 0.10 & 0.12 & 0.12 & 0.11 & 0.14 & 0.12 & 0.12 & 0.12 & 0.11 & 0.13 & 0.14 & 0.14 & 0.14 & 0.16 \\
\hline $\mathrm{MgO}$ & 8.85 & 10.54 & 13.30 & 14.17 & 10.87 & 10.17 & 9.96 & 8.90 & 12.20 & 9.89 & 8.53 & 6.55 & 7.49 & 6.64 & 8.73 \\
\hline $\mathrm{CaO}$ & 14.22 & 11.97 & 10.97 & 11.05 & 11.74 & 11.80 & 11.37 & 11.41 & 10.70 & 11.24 & 11.53 & 10.75 & 11.04 & 11.08 & 10.42 \\
\hline $\mathrm{Na}_{2} \mathrm{O}$ & 2.73 & 3.13 & 2.36 & 2.30 & 2.93 & 2.66 & 3.21 & 3.36 & 2.52 & 2.78 & 3.32 & 2.68 & 2.69 & 2.89 & 2.64 \\
\hline $\mathrm{K}_{2} \mathrm{O}$ & 0.33 & 0.17 & 0.18 & 0.14 & 0.13 & 0.20 & 0.22 & 0.23 & 0.29 & 0.17 & 0.34 & 0.79 & 0.62 & 0.64 & 0.44 \\
\hline $\mathrm{P}_{2} \mathrm{O}_{5}$ & 0.11 & 0.10 & 0.09 & 0.08 & 0.10 & 0.07 & 0.09 & 0.11 & 0.11 & 0.10 & 0.13 & 0.10 & 0.09 & 0.11 & 0.09 \\
\hline Total & 99.80 & 100.32 & 100.97 & 101.42 & 101.10 & 98.83 & 99.90 & 100.27 & 102.59 & 99.75 & 100.81 & 98.80 & 99.03 & 99.95 & 98.26 \\
\hline $\mathrm{Ni}$ & 117 & 114 & 382 & 426 & 108 & 253 & 151 & 123 & 174 & 116 & 114 & 128 & 133 & 134 & 269 \\
\hline $\mathrm{Cr}$ & 223 & 228 & 532 & 594 & 218 & 424 & 211 & 196 & 232 & 192 & 178 & 203 & 212 & 222 & 390 \\
\hline $\mathrm{Zn}$ & 53 & 48 & 52 & 53 & so & 54 & 57 & 62 & 55 & 56 & 61 & 63 & 62 & 63 & 66 \\
\hline Ga & 19 & 20 & 16 & 15 & 18 & 18 & 15 & 20 & 16 & 19 & 25 & 22 & 24 & 22 & 17 \\
\hline $\mathrm{Rb}$ & 4 & 1 & 2 & 1 & 1 & $<1$ & $<1$ & 2 & $<1$ & $<1$ & $<1$ & 8 & 5 & 3 & 3 \\
\hline $\mathrm{Sr}$ & 176 & 178 & 143 & 137 & 161 & 160 & 221 & 234 & 214 & 221 & 239 & 179 & 183 & 185 & 170 \\
\hline $\mathrm{Y}$ & 21 & 23 & 18 & 18 & 22 & 22 & 23 & 19 & 19 & 23 & 25 & 27 & 26 & 23 & 23 \\
\hline $\mathrm{Zr}$ & 61 & 63 & 58 & 51 & 58 & 55 & 62 & 73 & 62 & 68 & 72 & 82 & 78 & 81 & 77 \\
\hline $\mathrm{Nb}$ & $<1$ & 1 & $<1$ & 1 & 1 & 1 & $<1$ & $<1$ & $<1$ & $<1$ & 1 & 2 & 2 & 1 & 2 \\
\hline $\mathrm{Ba}$ & 25 & 41 & 49 & 43 & 42 & 10 & 34 & 191 & 64 & 52 & 134 & 82 & 70 & 94 & 105 \\
\hline $\mathrm{La}$ & 9 & 6 & 10 & 9 & 10 & 10 & 9 & 8 & 7 & 5 & 7 & 9 & 16 & 15 & 15 \\
\hline $\mathrm{Ce}$ & 9 & 12 & 4 & 9 & 10 & 7 & 10 & 7 & 10 & 14 & 8 & 12 & 11 & 9 & 13 \\
\hline $\mathrm{Nd}$ & 7 & 8 & 5 & 7 & 9 & 6 & 7 & 8 & 8 & 9 & 7 & 11 & 8 & 6 & 9 \\
\hline $\mathrm{Pb}$ & 5 & 1 & 6 & 6 & 5 & $<1$ & 7 & 9 & $<1$ & $<1$ & 4 & $<1$ & $<1$ & - & - \\
\hline Th & 6 & 1 & 1 & 2 & 4 & $<1$ & $<1$ & $<1$ & $<1$ & $<1$ & $<1$ & $<1$ & $<1$ & $<1$ & 2 \\
\hline $\mathrm{Zr} / \mathrm{Nb}$ & $>61.0$ & 63.0 & $>58.0$ & 51.0 & 58.0 & 55.0 & $>62.0$ & $>73.0$ & $>62.0$ & $>68.0$ & 72.0 & 41.0 & 39.0 & 81.0 & 39.0 \\
\hline $\mathrm{Ti} / \mathrm{Zr}$ & 87.0 & 90.0 & 89.0 & 97.0 & 97.0 & 96.0 & 88.0 & 79.0 & 85.0 & 85.0 & 87.0 & 86.0 & 89.0 & 89.0 & 87.0 \\
\hline $\mathrm{Y} / \mathrm{Zr}$ & 0.34 & 0.37 & 0.31 & 0.35 & 0.38 & 0.40 & 0.37 & 0.26 & 0.31 & 0.34 & 0.35 & 0.33 & 0.33 & 0.28 & 0.30 \\
\hline $\mathrm{Ce} / \mathrm{Zr}$ & 0.15 & 0.19 & 0.07 & 0.18 & 0.17 & 0.13 & 0.16 & 0.10 & 0.16 & 0.21 & 0.11 & 0.15 & 0.14 & 0.11 & 0.17 \\
\hline $\mathrm{Ba} / \mathrm{Zr}$ & 0.41 & 0.65 & 0.84 & 0.84 & 0.72 & 0.18 & 0.55 & 2.62 & 1.03 & 0.76 & 1.86 & 1.00 & 0.90 & 1.16 & 1.36 \\
\hline$(\mathrm{Ce} / \mathrm{Y})_{\mathrm{N}}$ & 1.05 & 1.28 & 0.55 & 1.23 & 1.12 & 0.78 & 1.07 & 0.90 & 1.29 & 1.50 & 0.79 & 1.09 & 1.04 & 0.96 & 1.39 \\
\hline $\mathrm{Fe} / \mathrm{Mg}$ & 1.11 & 0.94 & 0.82 & 0.77 & 0.96 & 1.07 & 0.97 & 1.11 & 0.83 & 1.04 & 1.23 & 1.67 & 1.46 & 1.61 & 1.32 \\
\hline $\mathrm{K} / \mathrm{Rb}$ & 689.0 & 1411.0 & 730.0 & 1179.0 & 1087.0 & $>1652.0$ & $>1835.0$ & 959.0 & $>2382.0$ & $>1436.0$ & $>2806.0$ & 816.0 & 1026.0 & 1760.0 & 1229.0 \\
\hline $\mathrm{Ba} / \mathrm{Sr}$ & 0.14 & 0.23 & 0.34 & 0.31 & 0.26 & 0.06 & 0.15 & 0.82 & 0.30 & 0.24 & 0.56 & 0.46 & 0.38 & 0.51 & 0.62 \\
\hline Q & 0.0 & 0.0 & 0.0 & 0.0 & 0.0 & 0.0 & 0.0 & 0.0 & 0.0 & 0.0 & 0.0 & 0.6 & 0.0 & 0.1 & 0.0 \\
\hline Or & 2.0 & 1.0 & 1.0 & 0.8 & 0.8 & 1.2 & 1.3 & 1.4 & 1.7 & 1.0 & 2.0 & 4.7 & 3.7 & 3.8 & 2.7 \\
\hline $\mathrm{Ab}$ & 17.9 & 24.3 & 19.8 & 19.2 & 24.5 & 22.8 & 27.2 & 28.4 & 20.8 & 23.6 & 27.9 & 23.0 & 23.0 & 24.5 & 22.7 \\
\hline An & 27.0 & 25.9 & 27.8 & 27.3 & 26.9 & 26.6 & 25.2 & 25.6 & 27.8 & 25.0 & 25.2 & 28.8 & 28.8 & 28.8 & 26.9 \\
\hline $\mathrm{Ne}$ & 2.8 & 1.1 & 0.0 & 0.0 & 0.0 & 0.0 & 0.0 & 0.0 & 0.0 & 0.0 & 0.0 & 0.0 & 0.0 & 0.0 & 0.0 \\
\hline $\mathrm{Di}$ & 34.8 & 26.2 & 20.5 & 21.1 & 24.2 & 26.1 & 24.7 & 24.4 & 18.7 & 24.4 & 24.9 & 20,1 & 21.1 & 20.9 & 20.5 \\
\hline $\mathrm{Hy}$ & 0.0 & 0.0 & 6.6 & 5.5 & 2.2 & 4.3 & 3.2 & 4.2 & 16.9 & 16.6 & 4.0 & 17.9 & 14.9 & 17.1 & 16.8 \\
\hline OI & 11.3 & 17.1 & 20.0 & 22.0 & 17.0 & 14.8 & 14.3 & 11.7 & 10.1 & 5.0 & 11.4 & 0.0 & 3.6 & 0.0 & 5.4 \\
\hline $\mathrm{Mt}$ & 1.5 & 1.5 & 1.6 & 1.6 & 1.5 & 1.7 & 1.5 & 1.5 & 1.5 & 1.5 & 1.6 & 1.7 & 1.7 & 1.6 & 1.8 \\
\hline II & 1.7 & 1.8 & 1.6 & 1.5 & 1.8 & 1.7 & 1.7 & 1.8 & 1.6 & 1.8 & 2.0 & 2.2 & 2.2 & 2.3 & 2.2 \\
\hline Ap & 0.3 & 0.2 & 0.2 & 0.2 & 0.2 & 0.2 & 0.2 & 0.3 & 0.2 & 0.2 & 0.3 & 0.2 & 0.2 & 0.3 & 0.2 \\
\hline
\end{tabular}

ally sparsely clinopyroxene and plagioclase phyric with more than 10 percent vesicles (and in some cases more than $30 \%$ ). The petrological and geochemical differences between the four units are subtle, and they have been distinguished by grain size, vesicularity, and magnetic intensity. The lavas contain up to about 3 percent $\mathrm{Fe}-\mathrm{Ti}$ oxides and patches of quartz and alkali feldspar in the mesostasis. They are relatively rich in $\mathrm{Fe}$ with between 10 and 14 weight percent $\mathrm{Fe}_{2} \mathrm{O}_{3}$. Some of the finegrained basalts contain spherulitic zones next to the vesicles with abundant needlelike opaque phases thought to be ilmenites.

The Site 459 basalts are quartz-normative and similar to primitive island arc tholeiites (Table 10 and Fig. 15) with low $\mathrm{Ti}$ and $\mathrm{Zr}$, high $\mathrm{K}$ and a depletion of $\mathrm{Ta}$ relative to $\mathrm{La}$ and $\mathrm{Th}$. The high vesicularity implies that the magmas from which the Site 459 basalts formed were rich in volatiles. Their low $\mathrm{Sr}(<150 \mathrm{ppm})$ and $\mathrm{Ba}$ (generally $<50 \mathrm{ppm}$ ) contents and depletion of the light REE (chondrite-normalized $\mathrm{La} / \mathrm{Tb}<1$ ) distinguish them from the calc-alkalic lavas from the Mariana Trough and Ridge.

\section{Site 460 \\ $\left(17^{\circ} 40.14^{\prime} \mathrm{N}, 147^{\circ} 35.92^{\prime} \mathrm{E}\right)$}

This site is located $25 \mathrm{~km}$ from the center of the Mariana Trench in a sediment pond on the arc-side wall of the trench in a water depth of 6445 meters. Basement was not reached, but basaltic clasts were recovered from a conglomerate of early Miocene or late Oligocene age (25-27 m.y.). Three such basalt clasts have been studied. Samples $460-9, C C, 11-13 \mathrm{~cm}$ and $460-9, C C$, $74-76 \mathrm{~cm}$ are sparsely plagioclase (about $2 \%$ ), olivine (rare pseudomorphs), and clinopyroxene (trace) phyric basalts with abundant vesicles (about 20\%). Sample $460 \mathrm{~A}-11-1,29-31 \mathrm{~cm}$ is an aphyric, coarse-grained basalt with abundant secondary amphibole replacing relict clinopyroxene. All three samples are primitive island arc tholeiites (Table 5) similar to those from Site 459 and Units 458-4a and 458-5 (Table 11). 

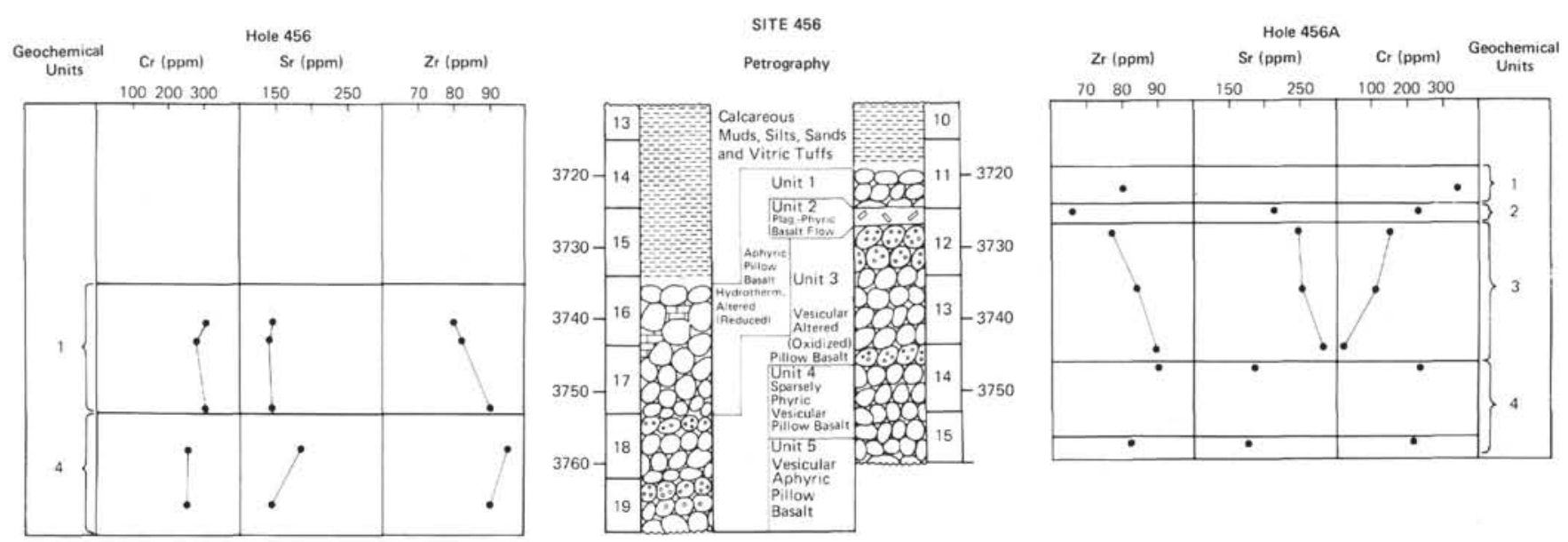

Figure 5. Geochemical and lithological stratigraphy of the basement sections of Holes 456 and 456A.

\section{Site 461}

$\left(17^{\circ} 46.01^{\prime} \mathrm{N}, 147^{\circ} 41.26^{\prime} \mathrm{E}\right)$

This site was located on a small patch of sediment on a local high in the arc-side wall of the Mariana Trench in a water depth of 7030 meters. Basement was not reached, but cobbles of igneous and metamorphic rocks were recovered in the few meters of sediment (about $20 \mathrm{~m}$ ) of uncertain age. One metabasalt sample of unknown petrography has been sampled and has a composition (Table 5) similar to that of the primitive arc tholeiites of the other fore-arc and trench sites (Table 11).

\section{DETAILED RELATIONSHIPS OF BASEMENT CHEMISTRY}

The lavas from these Mariana fore-arc and Trench sites can be divided into two groups: (1) the Mg-rich andesites and andesites from Site 458 which are related to a boninite magma type. The $\mathrm{Mg}$-rich andesites are probably derived from a boninite parental magma by crystal fractionation of the two pyroxene phases; (2) the primitive island arc tholeiites recovered from all four sites. Major and trace element variation diagrams for these rocks are presented in Figures 16 through 24. The $\mathrm{Mg}$-rich andesites and andesites of Site 458 Units 1 through 3 follow a trend toward enrichment of $\mathrm{Ca}$ and Al with decreasing $\mathrm{Mg}$ (Fig. 15). This suggests that plagioclase has not fractionated from these magmas, at least from the more primitive ones. The $\mathrm{Zr}$ and $\mathrm{Ti}$ contents remain approximately constant with decreasing $\mathrm{MgO}$ in these units.

The andesites of Unit 458-4 have higher $\mathrm{Fe}, \mathrm{Ti}$ and $\mathrm{Zr}$, but lower $\mathrm{Ca}$ and $\mathrm{Al}$ contents than the andesites of Units 458-1 through 3 with similar $\mathrm{MgO}$ contents (Fig. 16). Most of the Unit 458-4 andesites also have lower $\mathrm{K} / \mathrm{Zr}, \mathrm{Zr} / \mathrm{Y}, \mathrm{Sr} / \mathrm{Zr}$ ratios (Fig. 17) than the Units 458-1 through 3 . These differences suggest that the Unit 458-4 andesites cannot be related to the Units 458-1 through 3 lavas by crystal fractionation processes. These HYG element ratios should remain approximately constant during crystal fractionation of two pyroxene assemblage. Units 458-1 through 4 have similar $\mathrm{Ta} / \mathrm{Tb}, \mathrm{Th} / \mathrm{Tb}$, and $\mathrm{La} / \mathrm{Tb}$ ratios (Fig. 18) and have chondrite-normalized
$\mathrm{La} / \mathrm{Tb}$ and $\mathrm{La} / \mathrm{Eu}$ ratios less than 1. Most of the previously described boninite-like lavas have been slightly enriched in the light REE relative to the heavy, REE - that is, chondrite-normalized $\mathrm{La} / \mathrm{Tb}$ and $\mathrm{La} / \mathrm{Eu}$ ratios greater than 1 (e.g., Sun and Nesbitt, 1978; Hickey and Frey, 1979). Also, Units 458-1 through 4 have low $\mathrm{Ti} / \mathrm{Zr}$ (less than 75 ), $\mathrm{Y} / \mathrm{Ti}$, and $\mathrm{Y} / \mathrm{Zr}$ (less than 0.35 ) ratios (Figs. 17 and 21 ). The low $\mathrm{Ti} / \mathrm{Zr}$ ratios are characteristic of boninites from other localities (Sun and Nesbitt, 1978) and distinguish them from most other terrestrial magma types. Relative to estimated primordial mantle abundances for a chondritic earth model, $\mathrm{Zr}$ and $\mathrm{Hf}$ are enriched relative to $\mathrm{Eu}, \mathrm{Ti}, \mathrm{Tb}$, and $\mathrm{Y}$ in these lavas (Fig. 23) - a point also noted by Bougault et al. (this volume). The significant fractionation of $\mathrm{Ti}$, $\mathrm{Zr}$, and $\mathrm{Y}$ relative to each other is difficult to achieve by mineral-melt processes unless garnet is involved (the heavy REE, Y, and Ti are partitional into garnet preferentially to $\mathrm{Zr}$ ).

The primitive island arc tholeiite lavas from these sites have higher $\mathrm{Fe}, \mathrm{Ti}, \mathrm{P}$, and HYG elements, but lower $\mathrm{Ca}$ and $\mathrm{Al}$ contents than the andesites of Site 458 with similar $\mathrm{MgO}$ contents (Fig. 16). Moreover, they have lower $\mathrm{Sr} / \mathrm{Zr}, \mathrm{Zr} / \mathrm{Y}, \mathrm{Th} / \mathrm{Tb}, \mathrm{La} / \mathrm{Eu}, \mathrm{La} / \mathrm{Tb}$, and $\mathrm{Ta} / \mathrm{Tb}$ ratios (Figs. 17 and 18 ) and $\mathrm{Ni}$ and $\mathrm{Cr}$ abundances (Figs. 19 and 20). All these island arc tholeiites have $\mathrm{Ti} / \mathrm{Zr}$ ratios close to 100 (Fig. 21) - except Unit $458-4 \mathrm{a}$, which has low $\mathrm{Mg}$ and $\mathrm{Fe}$ and has probably resulted from crystal fractionation of an $\mathrm{Fe}-\mathrm{Ti}$ oxide phase which would reduce the $\mathrm{Ti} / \mathrm{Zr}$ ratios. Also they follow coherent trends on the trace element variation diagrams.

The lavas from the fore-arc and trench sites plot in a distinct and highly restricted field in the Th- Hf/3-Ta triangle (Fig. 22), close to the boundary between active margin and N-type MORB magma types. The andesites of Units 458-1 through 4 plot closer to the Th apex of the triangle than the arc tholeiites. All the lavas plot close to other primitive island arc tholeiites from the West Pacific active margins. However, these lavas are less depleted in Ta relative to the HYG elements than other active margin volcanics studied to date. This point 
Table 4. Major and trace element analyses of igneous rocks from Site 456.

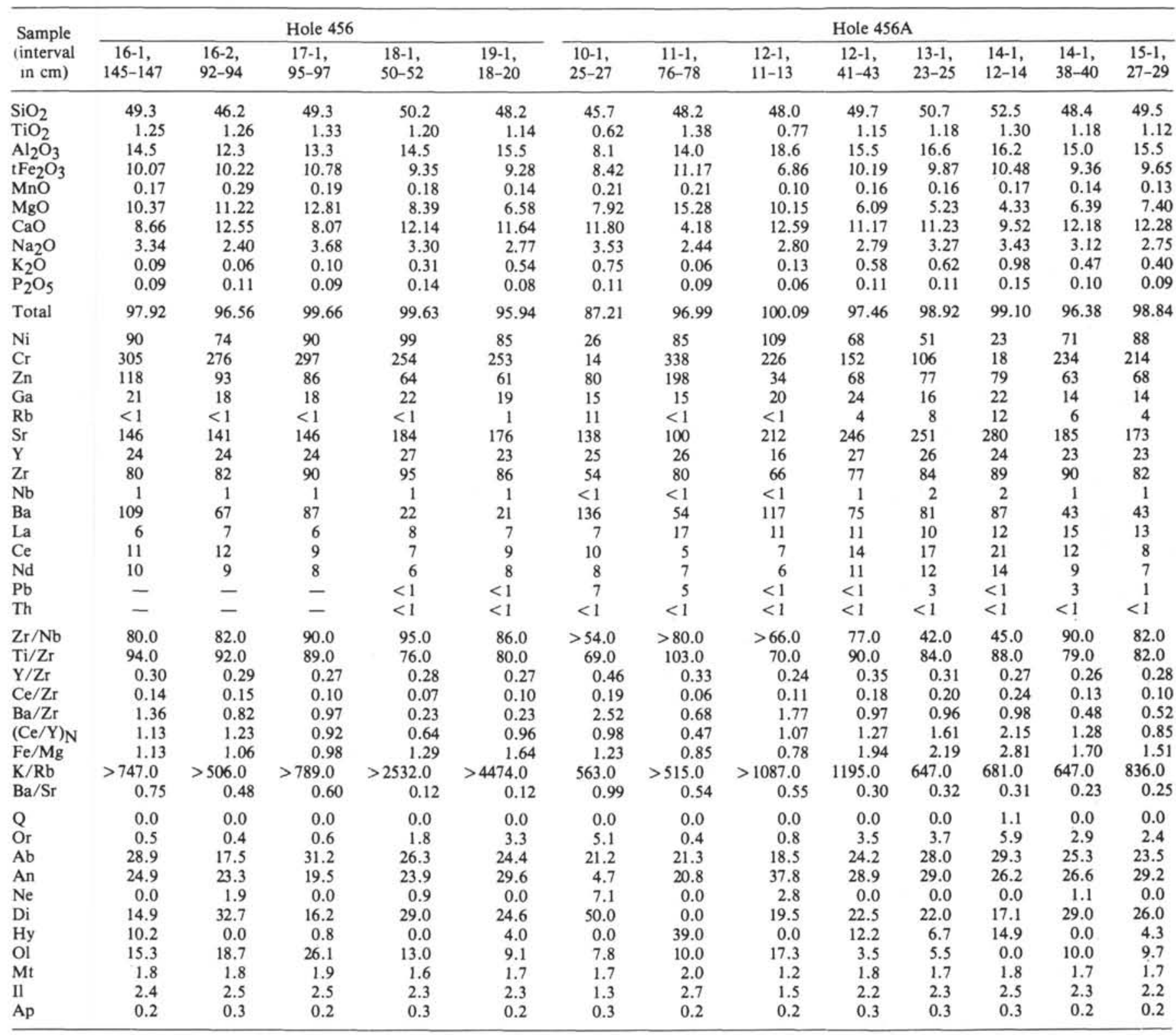

is also apparent from Figure 20. Comparing this figure with Figure 10, it can be seen that the fore-arc tholeiites have a much smaller depletion in Ta relative to $\mathrm{La}$ and $\mathrm{Ce}$, and the $\mathrm{Mg}$-rich andesites from Unit 458-1 show no depletion in Ta relative to La. Figure 24 illustrates the large range of $\mathrm{La} / \mathrm{Ta}$ ratios measured in the lavas recovered from the arcs and basins of the West Pacific Ocean; the Mariana fore-arc lavas and those from the Mariana Trough have $\mathrm{La}$ / $\mathrm{Ta}$ ratios less than 40 and, except for the Site 458 andesites, greater than 15; the lavas from Japan, the Mariana arc, the West Mariana Ridge and the Kyushu-Palau Ridge have $\mathrm{La} / \mathrm{Ta}$ ratios greater than 40 . These trace element variations suggest that several magma types, unrelated by crystal fractionation processes, have been erupted during the development of the island arcs and inter-arc basins of the west Pacific. The geochemical diversity of the lavas implies that the petrogenetic processes and mantle source compositions involved are complex.

\section{DISCUSSION}

The main aim of this chapter has been to provide a factual account of the geochemistry of Leg 60 igneous rocks. A detailed consideration of the petrogenetic implications of the data will be deferred to a subsequent paper. However, qualitative assessments can be made of some of the recently favored petrogenetic models for island arc and back-arc basin magmas, and constraints placed on them by the tectonic evolution of the Philippine Sea.

Most recent trace element and radiogenic isotope studies of continental margin, island arc, and marginal basin lavas have favored petrogenetic models invoking the involvement of fluids, probably of a supercritical 
Table 5. Major and trace element analyses of igneous rocks from Holes 457, 460, and 461 .

\begin{tabular}{|c|c|c|c|c|c|}
\hline \multirow{2}{*}{$\begin{array}{l}\text { Sample } \\
\text { (interval } \\
\text { in } \mathrm{cm} \text { ) }\end{array}$} & \multirow{2}{*}{$\frac{\text { Hole } 457}{4, C C}$} & \multicolumn{3}{|c|}{ Hole 460} & \multirow{2}{*}{ 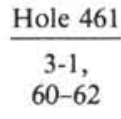 } \\
\hline & & $\begin{array}{l}9, \mathrm{CC}, \\
74-76\end{array}$ & $\begin{array}{l}9, \mathrm{CC} \\
11-13\end{array}$ & $\begin{array}{l}11-1 \\
29-31\end{array}$ & \\
\hline $\mathrm{SiO}_{2}$ & 53.4 & 52.5 & 53.6 & 55.5 & 58.7 \\
\hline $\mathrm{TiO}_{2}$ & 0.89 & 0.87 & 1.34 & 0.61 & 1.01 \\
\hline $\mathrm{Al}_{2} \overline{\mathrm{O}}_{3}$ & 15.6 & 15.2 & 16.6 & 13.3 & 13.2 \\
\hline $\mathrm{tFe}_{2} \mathrm{O}_{3}$ & 11.32 & 12.73 & 10.57 & 12.28 & 14.06 \\
\hline $\mathrm{MnO}$ & 0.14 & 0.13 & 0.07 & 0.11 & 0.13 \\
\hline $\mathrm{MgO}$ & 5.33 & 5.03 & 3.97 & 7.95 & 5.46 \\
\hline $\mathrm{CaO}$ & 6.47 & 8.24 & 5.45 & 5.23 & 3.00 \\
\hline $\mathrm{Na}_{2} \mathrm{O}$ & 2.73 & 3.06 & 5.51 & 3.84 & 3.50 \\
\hline $\mathrm{K}_{2} \mathrm{O}$ & 1.13 & 0.91 & 1.68 & 0.57 & 0.22 \\
\hline $\mathrm{P}_{2} \mathrm{O}_{5}$ & 0.11 & 0.05 & 0.23 & 0.04 & 0.08 \\
\hline Total & 97.09 & 98.75 & 99.00 & 99.40 & 99.43 \\
\hline $\mathrm{Ni}$ & 17 & 22 & 2 & 16 & 27 \\
\hline $\mathrm{Cr}$ & 29 & 51 & 5 & 10 & 15 \\
\hline $\mathrm{Zn}$ & 80 & 98 & 91 & 59 & 60 \\
\hline $\mathrm{Ga}$ & 16 & 18 & 25 & 16 & 17 \\
\hline $\mathrm{Rb}$ & 18 & 8 & 22 & 4 & 4 \\
\hline $\mathrm{Sr}$ & 305 & 122 & 154 & 104 & 113 \\
\hline $\mathrm{Y}$ & 19 & 17 & 52 & 15 & 16 \\
\hline $\mathrm{Zr}$ & 81 & 48 & 83 & 38 & 69 \\
\hline $\mathrm{Nb}$ & $<1$ & $<1$ & 1 & $<1$ & $<1$ \\
\hline $\mathrm{Ba}$ & 255 & 21 & 66 & 37 & 36 \\
\hline La & 16 & 11 & 12 & 10 & 11 \\
\hline $\mathrm{Ce}$ & 17 & 10 & 16 & 9 & 7 \\
\hline Nd & 12 & 5 & 11 & 5 & 6 \\
\hline $\mathrm{Pb}$ & 5 & 8 & 8 & 5 & 2 \\
\hline Th & $<1$ & 2 & $<1$ & 1 & 4 \\
\hline $\mathrm{Zr} / \mathrm{Nb}$ & $>81.0$ & $>48.0$ & 83.0 & $>38.0$ & $>69.0$ \\
\hline $\mathrm{Ti} / \mathrm{Zr}$ & 66.0 & 108.0 & 96.0 & 97.0 & 88.0 \\
\hline $\mathrm{Y} / \mathrm{Zr}$ & 0.23 & 0.35 & 0.63 & 0.39 & 0.23 \\
\hline $\mathrm{Ce} / \mathrm{Zr}$ & 0.21 & 0.21 & 0.19 & 0.24 & 0.10 \\
\hline $\mathrm{Ba} / \mathrm{Zr}$ & 3.15 & 0.44 & 0.80 & 0.97 & 0.52 \\
\hline$(\mathrm{Ce} / \mathrm{Y})_{\mathrm{N}}$ & 2.20 & 1.44 & 0.76 & 1.47 & 1.07 \\
\hline $\mathrm{Fe} / \mathrm{Mg}$ & 2.46 & 2.93 & 3.09 & 1.79 & 2.99 \\
\hline $\mathrm{K} / \mathrm{Rb}$ & 521.0 & 940.0 & 634.0 & 1185.0 & 465.0 \\
\hline $\mathrm{Ba} / \mathrm{Sr}$ & 0.84 & 0.17 & 0.43 & 0.36 & 0.32 \\
\hline Q & 6.4 & 2.3 & 0.0 & 2.6 & 15.2 \\
\hline Or & 6.9 & 5.4 & 10.0 & 3.4 & 1.3 \\
\hline $\mathrm{Ab}$ & 23.8 & 26.2 & 45.8 & 32.7 & 29.8 \\
\hline An & 27.7 & 25.5 & 15.7 & 17.4 & 14.5 \\
\hline $\mathrm{Ne}$ & 0.0 & 0.0 & 0.7 & 0.0 & 0.0 \\
\hline Di & 4.0 & 13.1 & 8.5 & 6.9 & 0.0 \\
\hline Hy & 26.3 & 22.4 & 0.0 & 32.5 & 31.4 \\
\hline $\mathrm{Ol}$ & 0.0 & 0.0 & 13.4 & 0.0 & 0.0 \\
\hline $\mathrm{Mt}$ & 2.0 & 2.2 & 1.9 & 2.1 & 2.5 \\
\hline Il & 1.7 & 1.7 & 2.6 & 1.2 & 1.9 \\
\hline Ap & 0.3 & 0.1 & 0.5 & 0.1 & 0.2 \\
\hline
\end{tabular}

saline and siliceous nature, derived from the subducted oceanic lithosphere and infiltrating the mantle wedge above the Benioff zone from which the lavas are subsequently derived (Best, 1975; Hawkesworth et al., 1978; Saunders and Tarney, 1979; Saunders et al., 1980). This process would cause the mantle wedge above the subducted plate to become enriched in the mobile elements ( $\mathrm{Cs}, \mathrm{K}, \mathrm{Rb}, \mathrm{Pb}, \mathrm{Ba}, \mathrm{Th}, \mathrm{U}, \mathrm{La}$, and $\mathrm{Sr}$ ) which can be leached to varying degrees from altered oceanic crust after subduction. Because the altered oceanic crust is hydrated with sea water, hydrous fluids derived from it would be enriched in ${ }^{87} \mathrm{Sr}$ relative to radiogenic $\mathrm{Nd}(\mathrm{Nd}$ content of sea water is very low). In addition, subducted sediments would also be expected to contribute certain mobile elements and radiogenic $\mathrm{Pb}$ to the fluids (Sun, 1980). Variations in the composition of the sediments and the proportions to which they contribute to fluids emanating from subducted oceanic crust might explain the geochemical diversity observed in arc magma types as a whole (e.g., the large range of HYG element ratios, such as $\mathrm{Ba} / \mathrm{La}$ ). However, we note that recent $\mathrm{Pb}, \mathrm{Sr}$, and $\mathrm{Nd}$ isotopic data for the Mariana arc (Meijer, 1976; DePaolo and Wasserburg, 1977; Dixon and Batiza, 1979; Stern, 1979) suggest that sediment contamination of the mantle source is minimal $(<2 \%)$.

The introduction of a hydrous fluid into the mantle wedge would lower the solidus and induce partial melting under conditions of high $P_{\mathrm{H}_{2} \mathrm{O}}$. The HYG element variations measured in the active margin volcanics of the west Pacific are certainly consistent with this model. In order to be able to explain the extremely low $\mathrm{Ta}$ and $\mathrm{Nb}$ abundances in active margin volcanics in general (Wood et al., 1979b), it is necessary to invoke that these elements are held in a mineral phase in the mantle during the partial melting (Wood, 1979; Saunders et al., 1980). Ta and $\mathrm{Nb}$ are strongly partitioned into titanium mineral phases - for example, rutile and sphene. Recent experimental studies have shown that the stabilities of rutile and sphene are enhanced under hydrous conditions and may be refractory phases with even high degrees of melting of mafic material (Hellman and Green, 1979).

The major and trace element compositions of the $\mathrm{Mg}$-rich andesites from Site 458 and boninite lavas can, in general terms, be reconciled with this model. Their major element compositions are similar to liquids produced experimentally by high degrees of partial melting of a hydrous peridotite at low pressures, $\sim 10$ kbars (Green, 1976). They have generally been interpreted as near-primary magmas derived by greater than 20 percent partial melting of a hydrous mantle source at depths less than $30 \mathrm{~km}$ (Sun and Nesbitt, 1978). The low absolute abundances of the immobile HYG elements in these lavas support a model invoking high degrees of partial melting. The absence of a negative Ta anomaly in the Site 458 andesites could reflect the total consumption of mantle titanium phases during high degrees of partial melting.

The Mg-rich andesites do show compositional relationships with other arc magma types for example, enrichment in volatile and mobile elements-yet there are some significant differences which suggest that they are not derived from the same mantle sources. For example, the high $\mathrm{Zr} / \mathrm{Ti}$ and $\mathrm{Ti} / \mathrm{Y}$ ratios of the $\mathrm{Mg}$-rich andesites are similar to those observed in calc-alkaline magmas and probably indicate the involvement of garnet in their genesis; yet they are depleted in the light REE, whereas the calc-alkaline magmas are enriched. However, we note that previously described boninites are light-REEenriched, and the Site $458 \mathrm{Mg}$-rich andesites are less depleted in the light REE than the island arc tholeiites with which they are associated. The $\mathrm{Mg}$-rich andesites of Site 458 differ from primitive island arc tholeiites in being less depleted in the light REE and in having high $\mathrm{Zr} / \mathrm{Ti}$ and $\mathrm{Ti} / \mathrm{Y}$ ratios. Overall the $\mathrm{Mg}$-rich andesites 


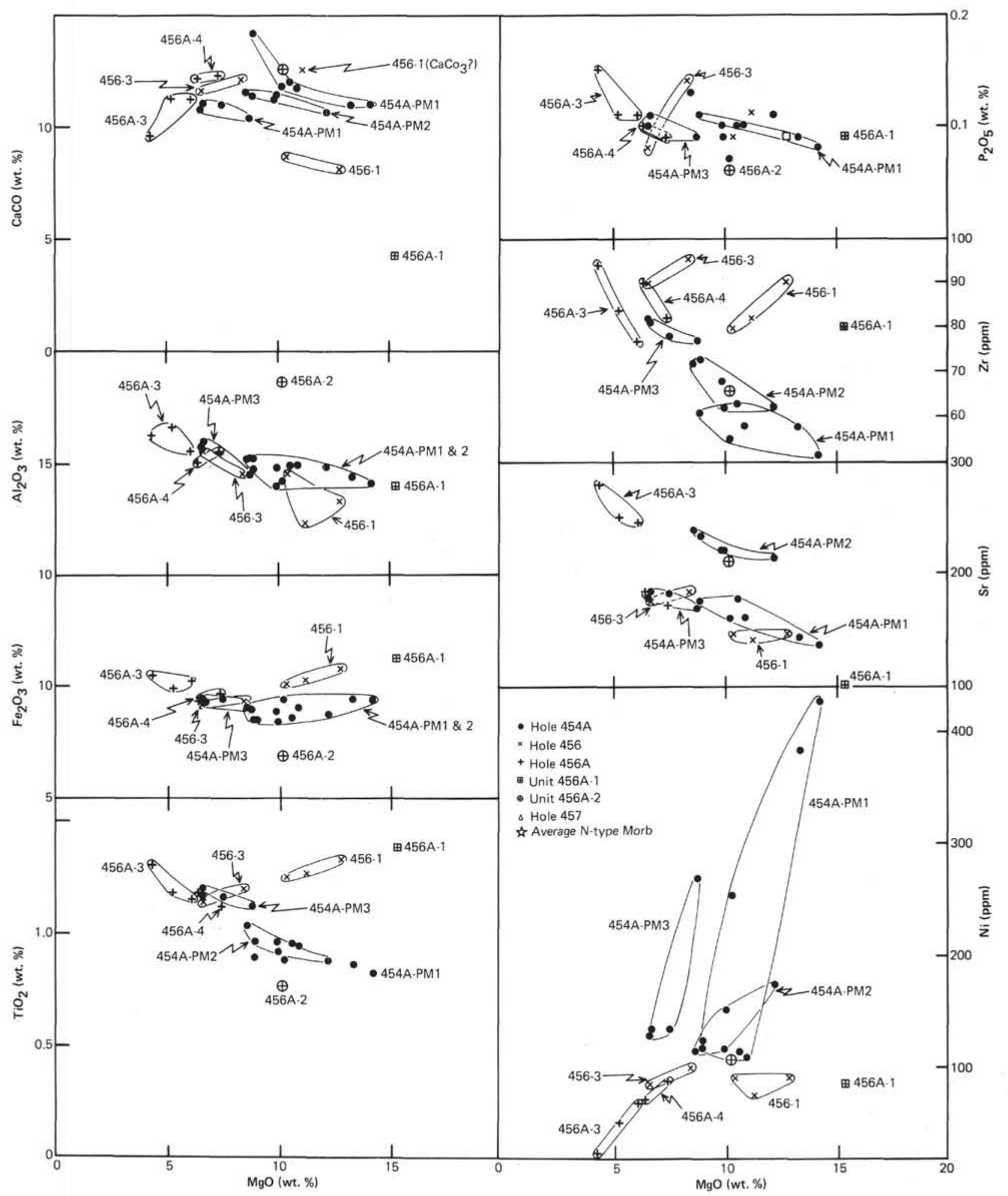

Figure 6. $\mathrm{MgO}$ variation diagram of selected major and trace elements for samples from Sites 454 and 456. 


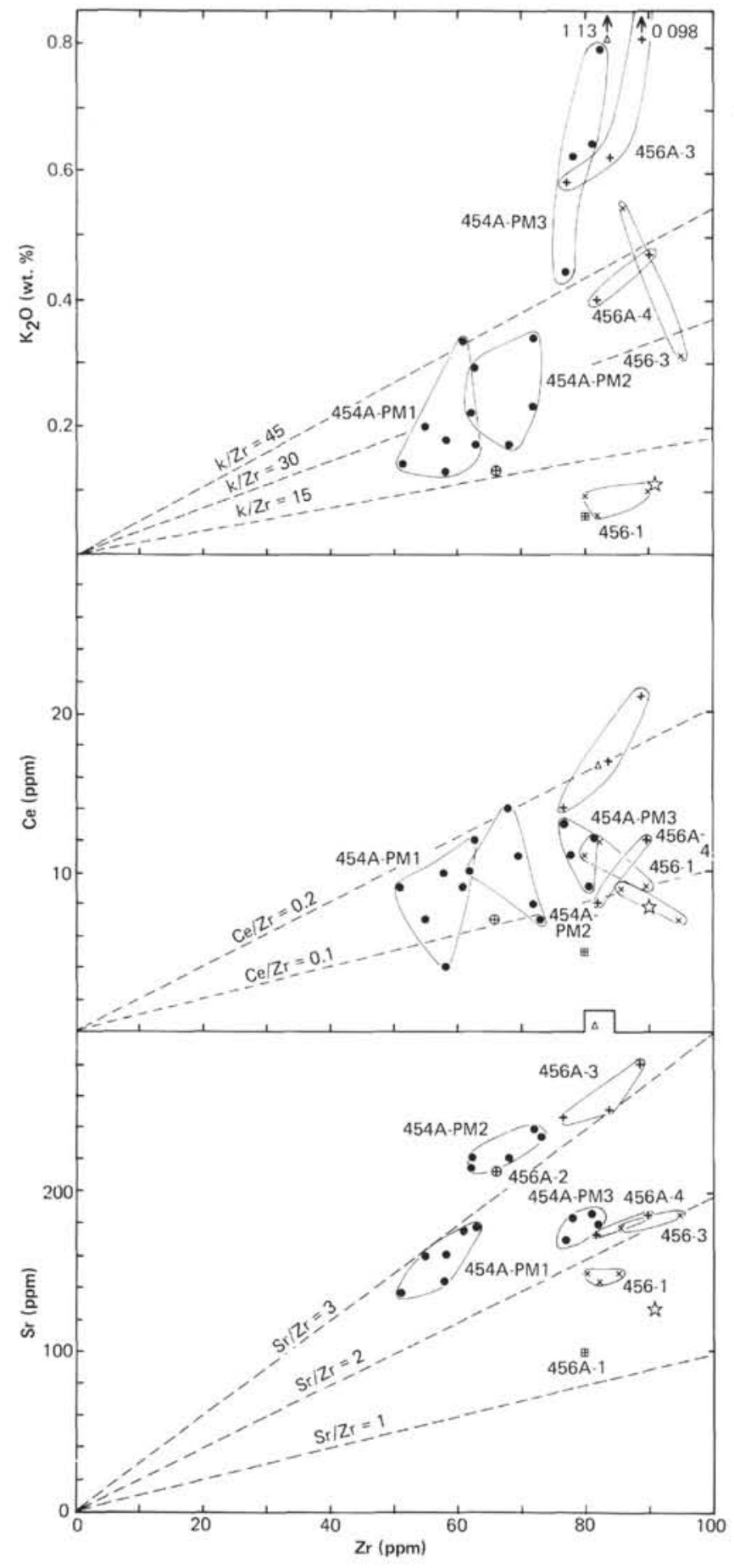

Figure 7. $\mathrm{K}_{2} \mathrm{O}, \mathrm{Ce}$, and $\mathrm{Sr}$ versus $\mathrm{Zr}$ for samples from Sites 454,456 , and 457. Average N-type MORB from Wood (1979). (See Fig. 6 for legend.)

have more compositional similarities with calc-alkaline magma types than primitive island arc tholeiites. There are two important features of $\mathrm{Mg}$-rich andesites and boninites which need to be considered when developing petrogenetic models for them: (1) They appear to be limited to the fore-arc of the West Pacific active margin and associated with the early development of an island arc system. (2) Their chemical compositions apparently result from high degrees of partial melting in the mantle

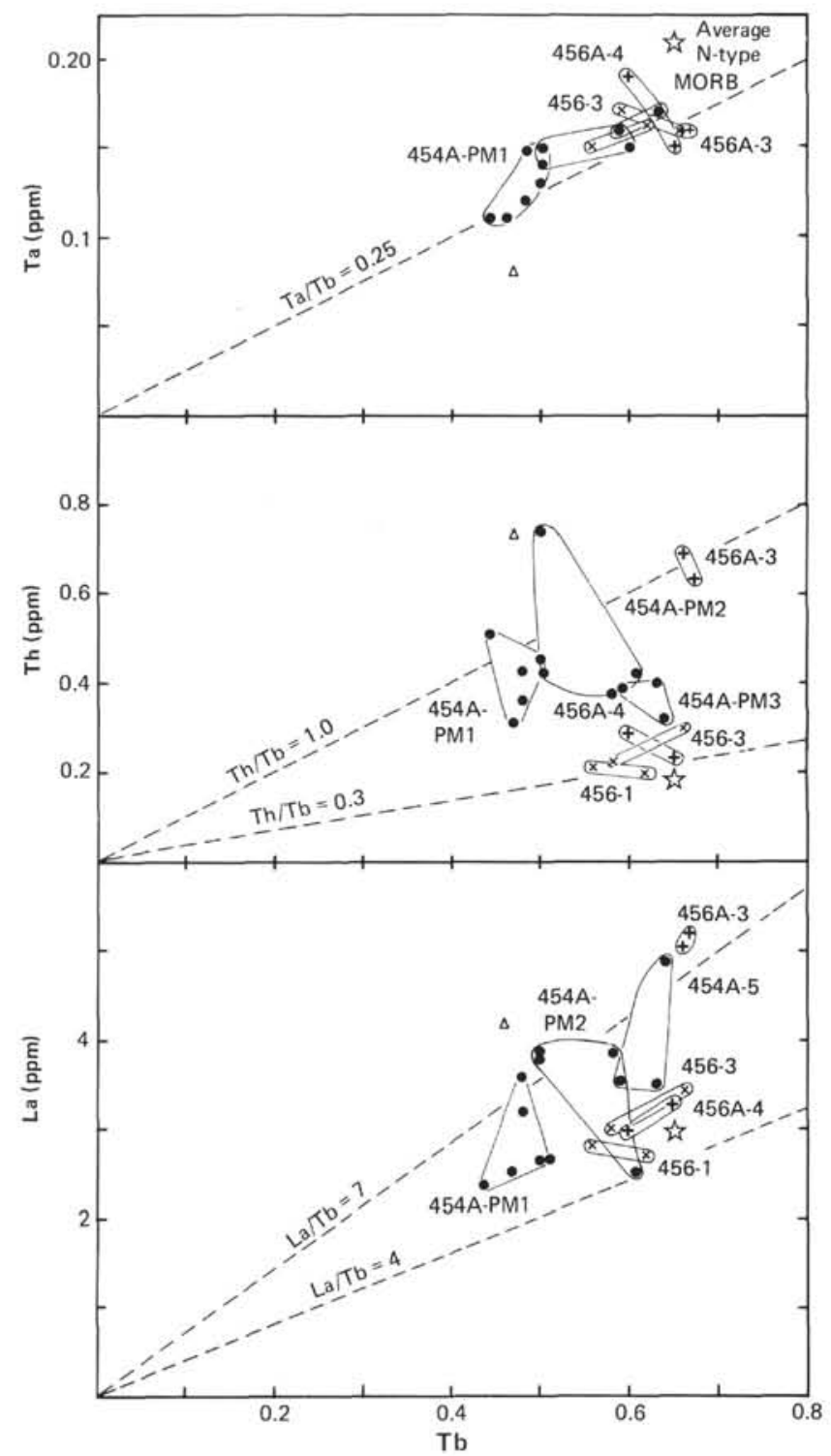

Figure 8. Ta, Th, and La versus $\mathrm{Tb}$ for samples from Sites 454, 456, and 457. (See Fig. 6 for legend.)

source under hydrous conditions, which suggests certain thermal energy requirements.

The source of the Mg-rich andesites could be in the mantle wedge where the addition of excess slab-derived hydrous fluids temporarily suppresses its solidus below the geotherm and initiated extensive partial melting. As the descending slab tends to cool the mantle wedge as subduction continues, the solidus of the mantle wedge would cease to be significantly depressed below the geotherm. The Site $458 \mathrm{Mg}$-rich andesites overlie islandarc tholeiitic lavas which are more depleted in the light REE. The arc tholeiites could be generated during the initial stages of hydrous metasomatism of the previously depleted mantle wedge by small degrees of partial melting. More extensive metasomatism would enrich the source in a number of HYG elements as well as depressing its solidus and increasing the degree of partial melting so as to produce boninite-like magmas. As 


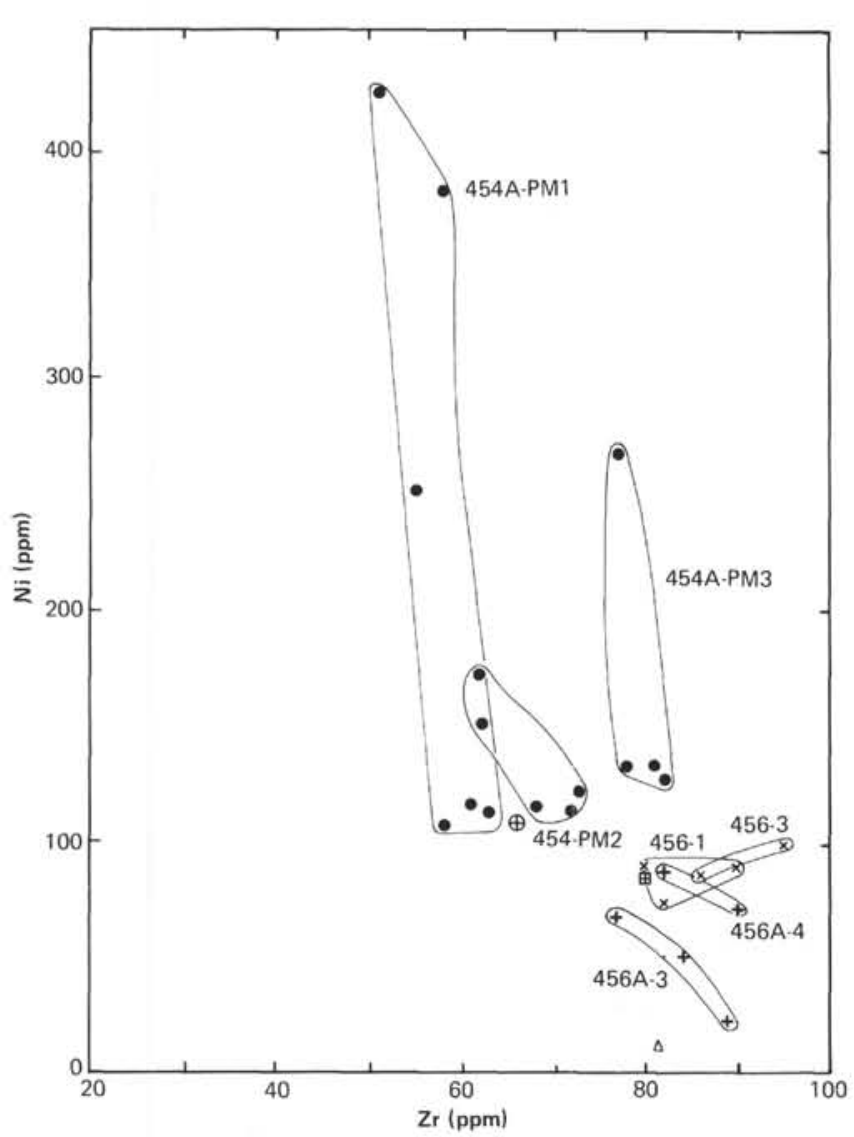

Figure 9. $\mathrm{Ni}$ versus $\mathrm{Zr}$ for samples from Sites 454, 456, and 457. (See Fig. 6 for legend.)

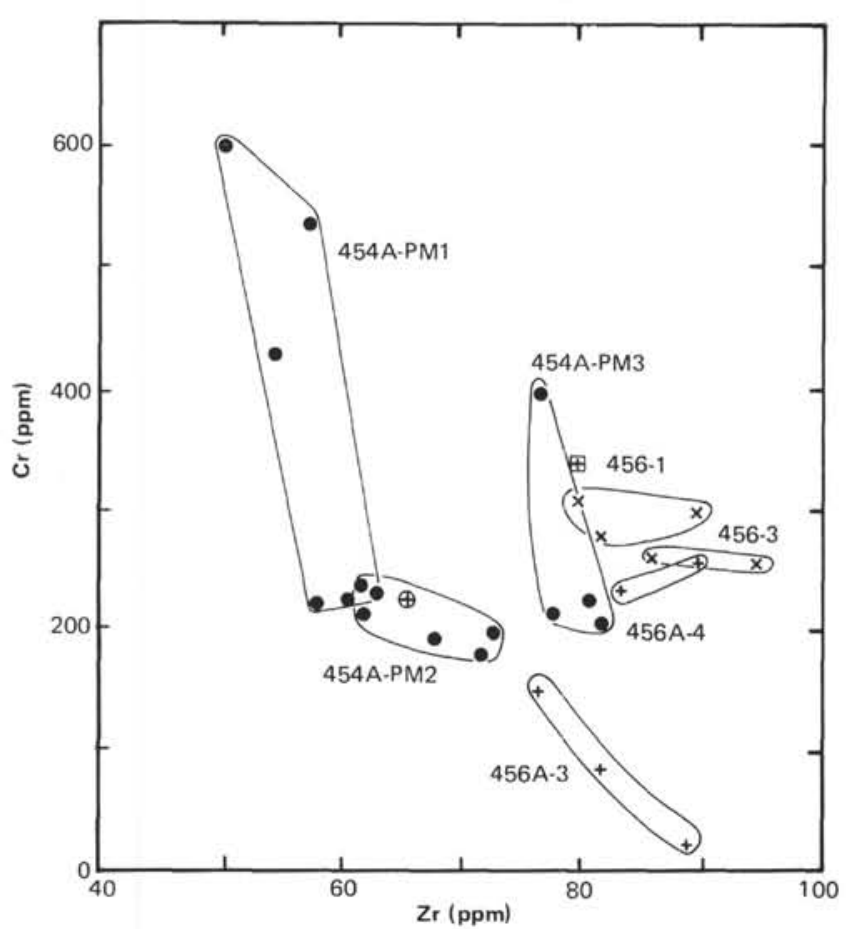

Figure 10. $\mathrm{Cr}$ versus $\mathrm{Zr}$ for samples from Sites 454,456 , and 457. (See Fig. 6 for legend.)

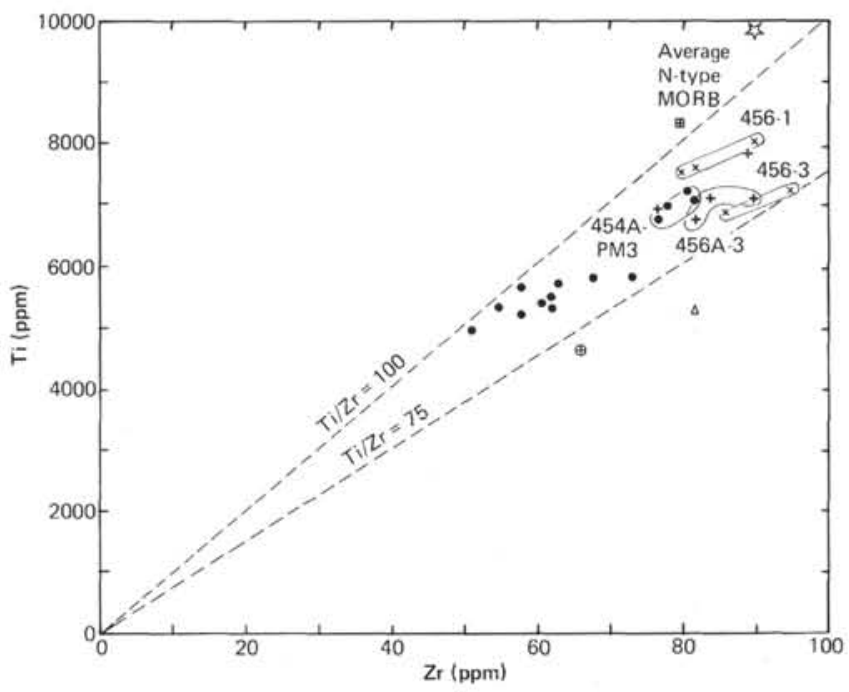

Figure 11. Ti versus $\mathrm{Zr}$ for samples from Sites 454, 456, and 457. (See Fig. 6 for legend.)

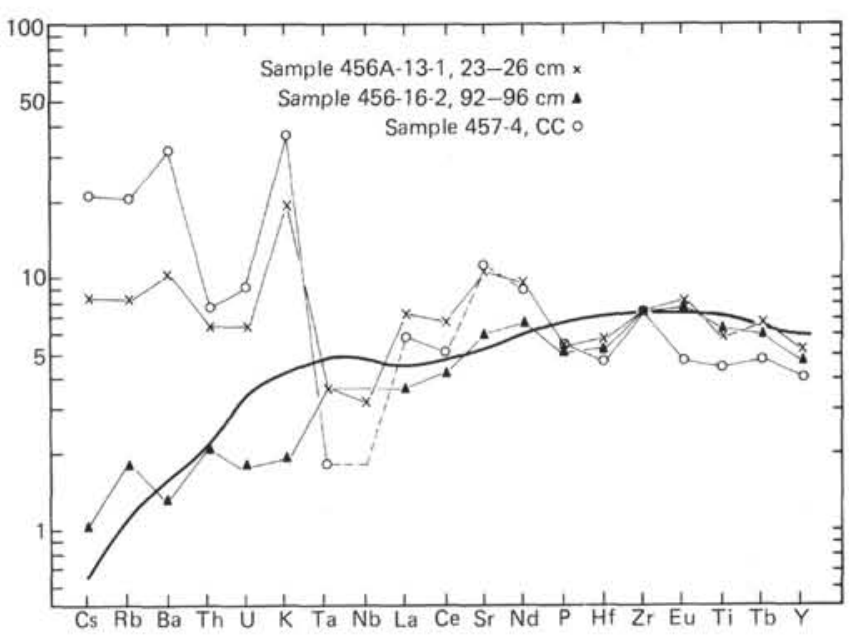

Figure 12. HYG element abundances of selected samples from Sites 456 and 457 normalized to estimated primordial mantle abundances (from Wood, 1979, except that a Ti value of $1500 \mathrm{ppm}$ is used here). Continuous line is average $\mathrm{N}$-type MORB.

metasomatism continued to cool and enrich the mantle wedge, the degree of partial melting would decrease and the magmas would develop a more calc-alkaline composition.

Alternatively, the difference between calc-alkaline and primitive island arc tholeiites could result from the mantle sources of the latter being metasomatized by hydrous fluids driven off the subducted slab at low pressures (perhaps during the prograde metamorphic reaction of greenschist to amphibolite), and the former from material infiltrated (veined) by hydrous melts (or fluids) derived from the slab at higher pressures (perhaps during the prograde metamorphic reaction amphibolite to eclogite). Ringwood (1974) proposed the involvement of a liquid component derived by partial 


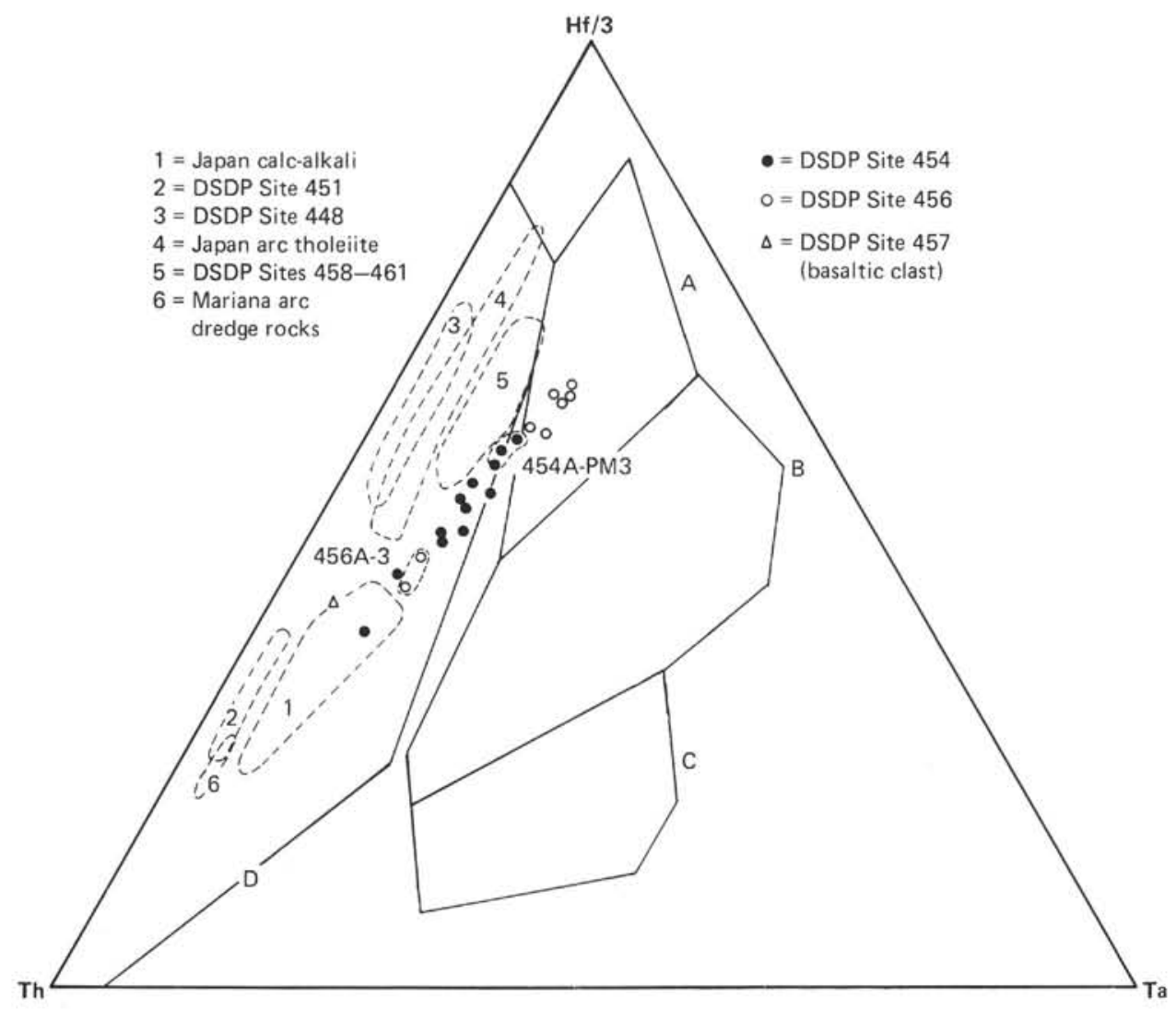

Figure 13. Th-Hf/3-Ta discrimination diagram (Wood et al., 1979b; Wood, 1980) for samples from Sites 454,456 , and 457 . Areas: $\mathrm{A}=\mathrm{N}$-type MORB; $\mathrm{B}=\mathrm{E}$-type MORB; $\mathrm{C}=$ within plate lavas; $\mathrm{D}=$ active plate margin lavas. The fields of Japanese lava series and DSDP Leg 59 samples are from Wood et al., 1980a, 1980b.

melting of quartz eclogite in the genesis of calc-alkaline magmas. The partial dehydration of the slab at low pressures would leach much of the radiogenic $\mathrm{Sr}$ added to the ocean crust during alteration, so that the residue involved in the amphibolite to eclogite transformation could be isotopically similar to MORB. This might explain the low ${ }^{87} \mathrm{Sr} /{ }^{86} \mathrm{Sr}(\sim 0.7032-0.7034)$ of the Mariana arc calc-alkaline lavas (Dixon and Batiza, 1979).

The most recent models for the tectonic evolution of the Mariana type plate boundary require that the position of the trench remains approximately fixed relative to the mantle. Poehls (1978) proposed that the Mariana Trough and other back-arc basins are caused by interaction between the subducted plate and the plate behind the trench in places where trenches are terminated or offset due to variations in subduction rates along the plate margin. He envisaged the slowing of the subduction rate where aseismic ridges (in this case the Caroline Ridge) collide with island arcs (Vogt et al., 1976). In this model the strike-slip motions occurring in the southern Marianas have induced the opening of the Mariana Trough, but the Mariana Trench has remained fixed. In their recent model, Uyeda and Kanamori (1979) propose that it is the westward motion of the Eurasian plate in the Philippine Sea area that has caused back arc extension in the area. In this model the downgoing slab is anchored to the mantle, and therefore the position of the trench remains fixed relative to the mantle.
Mattey et al. (1980) have pointed out that if the trench remains fixed relative to the mantle, the same mantle wedge would remain coupled to the Benioff zone and be repeatedly infiltrated with fluids or melts derived from the subducted plate. Moreover, these models imply that the Kyushu-Palau Ridge and West Mariana Ridge would have formed in the same position relative to the trench and Benioff zone as the active Mariana arc. The Parece Vela Basin (Fig. 1) was the first backarc basin to open as a response to westerly movement of the West Philippine Basin or a strike-slip movement in the regions of the Palau and Yap Trenches. The arc magmatism became more calc-alkaline, forming the West Mariana Ridge followed by back-arc extension in the Mariana Trough.

Considered in these terms the observed temporal variations in the geochemistry of the lavas erupted in the Mariana system may be able to constrain some of the petrogenetic models: the lavas from the Mariana forearc and Kyushu-Palau Ridge are primitive arc tholeiites (although we note that there are some systematic differences in the trace element ratios of lavas from the two regions, e.g., La/Ta, Fig. 24); lavas from the younger West Mariana Ridge and active Mariana arc are calcalkaline, as are some of the lavas in the Mariana Trough. Thus, there is a trend from early primitive island-arc tholeiites to subsequent calc-alkaline lavas erupted in the Mariana system. These variations suggest 
Table 6. Major and trace element analyses of Recent basalts and andesites dredged from a seamount (latitude $21^{\circ} 57^{\prime} \mathrm{N}$, longitude $143^{\circ} 27^{\prime} \mathrm{E}$ ) in the northern Mariana arc.

\begin{tabular}{|c|c|c|c|c|c|c|c|c|c|c|c|c|c|}
\hline & $\begin{array}{c}\text { Andesites } \\
\text { MV } \\
1801\end{array}$ & $\begin{array}{c}\text { MV } \\
1802\end{array}$ & $\begin{array}{c}\text { MV } \\
1803\end{array}$ & $\begin{array}{c}\text { MV } \\
1804\end{array}$ & $\begin{array}{c}\text { MV } \\
15101\end{array}$ & $\begin{array}{c}\text { MV } \\
15117\end{array}$ & $\begin{array}{c}\text { MV } \\
15146\end{array}$ & $\begin{array}{c}\text { MV } \\
15188\end{array}$ & $\begin{array}{c}\text { MV } \\
15197\end{array}$ & $\begin{array}{c}\text { MV } \\
15220\end{array}$ & $\begin{array}{c}\text { MV } \\
15214\end{array}$ & $\begin{array}{c}\text { MV } \\
15268\end{array}$ & $\begin{array}{c}\text { MV } \\
15295\end{array}$ \\
\hline $\mathrm{SiO}_{2}$ & 53.1 & 51.5 & 52.8 & 54.2 & 55.3 & 60.6 & 56.7 & 52.7 & 56.9 & 55.3 & 55.5 & 53.0 & 55.4 \\
\hline $\mathrm{TiO}_{2}$ & 0.82 & 0.74 & 0.80 & 0.82 & 1.13 & 1.11 & 1.28 & 0.79 & 1.13 & 1.14 & 0.92 & 0.88 & 0.88 \\
\hline $\mathrm{Al}_{2} \mathrm{O}_{3}$ & 19.1 & 18.3 & 18.6 & 19.7 & 15.0 & 14.0 & 13.8 & 18.7 & 15.1 & 14.8 & 16.6 & 18.6 & 16.9 \\
\hline $\mathrm{tFe}_{2} \mathrm{O}_{3}$ & 8.51 & 8.48 & 8.76 & 8.69 & 10.91 & 9.91 & 11.43 & 9.38 & 10.12 & 11.04 & 9.13 & 9.82 & 9.90 \\
\hline $\mathrm{MnO}$ & 0.13 & 0.13 & 0.14 & 0.13 & 0.18 & 0.19 & 0.18 & 0.15 & 0.16 & 0.18 & 0.15 & 0.15 & 0.17 \\
\hline $\mathrm{MgO}$ & 2.75 & 4.03 & 2.91 & 2.61 & 2.89 & 1.98 & 2.86 & 3.58 & 2.61 & 3.17 & 2.36 & 3.21 & 3.92 \\
\hline $\mathrm{CaO}$ & 10.49 & 10.71 & 10.48 & 10.39 & 7.89 & 5.32 & 6.99 & 10.82 & 7.26 & 8.02 & 7.93 & 10.56 & 9.58 \\
\hline $\mathrm{Na}_{2} \mathrm{O}$ & 2.57 & 2.34 & 2.52 & 2.67 & 2.73 & 3.64 & 3.08 & 2.51 & 2.92 & 2.64 & 2.71 & 2.56 & 2.50 \\
\hline $\mathrm{K}_{2} \mathrm{O}$ & 0.92 & 1.20 & 0.58 & 1.13 & 1.21 & 1.47 & 1.29 & 0.89 & 1.41 & 1.20 & 1.22 & 1.02 & 1.01 \\
\hline $\mathrm{P}_{2} \mathrm{O}_{5}$ & 0.12 & 0.15 & 0.11 & 0.18 & 0.15 & 0.24 & 0.15 & 0.11 & 0.18 & 0.14 & 0.13 & 0.14 & 0.12 \\
\hline Total & 98.51 & 97.49 & 97.66 & 100.51 & 97.39 & 98.47 & 97.81 & 99.61 & 97.73 & 97.56 & 96.73 & 99.99 & 100.37 \\
\hline $\mathrm{Ni}$ & 4 & 36 & 4 & 6 & 1 & $<1$ & $<1$ & 9 & $<1$ & 3 & $<1$ & 4 & 13 \\
\hline $\mathrm{Cr}$ & 13 & 104 & 13 & 10 & 11 & $<1$ & 6 & 25 & 9 & 10 & 4 & 11 & 38 \\
\hline $\mathrm{Zn}$ & 69 & 63 & 69 & 65 & 96 & 110 & 99 & 74 & 98 & 99 & 91 & 92 & 82 \\
\hline $\mathrm{Ga}$ & 17 & 18 & 18 & 18 & 8 & 14 & 17 & 17 & 16 & 14 & 15 & 17 & 14 \\
\hline $\mathrm{Rb}$ & 20 & 28 & 12 & 24 & 25 & 32 & 29 & 19 & 37 & 26 & 29 & 23 & 23 \\
\hline $\mathrm{Sr}$ & 457 & 477 & 501 & 495 & 387 & 358 & 340 & 482 & 370 & 395 & 414 & 513 & 395 \\
\hline $\mathrm{Y}$ & 17 & 19 & 19 & 20 & 28 & 40 & 33 & 19 & 31 & 29 & 27 & 20 & 24 \\
\hline $\mathrm{Zr}$ & 62 & 76 & 57 & 68 & 82 & 105 & 98 & 59 & 105 & 82 & 87 & 65 & 66 \\
\hline $\mathrm{Nb}$ & $<1$ & $<1$ & $<1$ & 2 & 2 & 2 & 3 & 2 & 3 & $<1$ & $<1$ & 1 & $<1$ \\
\hline $\mathrm{Ba}$ & 331 & 283 & 307 & 337 & 481 & 633 & 536 & 327 & 555 & 476 & 509 & 340 & 388 \\
\hline $\mathrm{La}$ & 10 & 13 & 11 & 11 & 15 & 19 & 17 & 11 & 17 & 17 & 15 & 13 & 11 \\
\hline $\mathrm{Ce}$ & 25 & 30 & 26 & 28 & 38 & 44 & 32 & 25 & 43 & 37 & 34 & 32 & 27 \\
\hline $\mathrm{Nd}$ & 13 & 18 & 14 & 16 & 20 & 25 & 20 & 13 & 22 & 20 & 19 & 16 & 16 \\
\hline $\mathrm{Pb}$ & 4 & 6 & 8 & 10 & 12 & 7 & 10 & 7 & 8 & 9 & 10 & 9 & 5 \\
\hline Th & 4 & 6 & 3 & 5 & 8 & 6 & 9 & 6 & 7 & 7 & 6 & 5 & 8 \\
\hline $\mathrm{Zr} / \mathrm{Nb}$ & $>62.0$ & $>76.0$ & $>57.0$ & 34.0 & 41.0 & 52.0 & 33.0 & 29.0 & 35.0 & $>82.0$ & $>87.0$ & 65.0 & $>66.0$ \\
\hline $\mathrm{Ti} / \mathrm{Zr}$ & 79.0 & 58.0 & 84.0 & 72.0 & 83.0 & 63.0 & 78.0 & 80.0 & 65.0 & 83.0 & 63.0 & 81.0 & 80.0 \\
\hline $\mathrm{Y} / \mathrm{Zr}$ & 0.27 & 0.25 & 0.33 & 0.29 & 0.34 & 0.38 & 0.34 & 0.32 & 0.30 & 0.35 & 0.31 & 0.31 & 0.36 \\
\hline $\mathrm{Ce} / \mathrm{Zr}$ & 0.40 & 0.39 & 0.46 & 0.41 & 0.46 & 0.42 & 0.33 & 0.42 & 0.41 & 0.45 & 0.39 & 0.49 & 0.41 \\
\hline $\mathrm{Ba} / \mathrm{Zr}$ & 5.34 & 3.72 & 5.39 & 4.96 & 5.87 & 6.03 & 5.47 & 5.54 & 5.29 & 5.80 & 5.85 & 5.23 & 5.88 \\
\hline$(\mathrm{Ce} / \mathrm{Y})_{\mathrm{N}}$ & 3.61 & 3.88 & 3.36 & 3.44 & 3.33 & 2.70 & 2.38 & 3.23 & 3.41 & 3.13 & 3.09 & 3.93 & 2.76 \\
\hline $\mathrm{Fe} / \mathrm{Mg}$ & 3.59 & 2.44 & 3.49 & 3.86 & 4.38 & 5.80 & 4.63 & 3.04 & 4.50 & 4.04 & 4.49 & 3.55 & 2.93 \\
\hline $\mathrm{K} / \mathrm{Rb}$ & 382.0 & 326.0 & 401.0 & 391.0 & 402.0 & 381.0 & 369.0 & 389.0 & 316.0 & 383.0 & 349.0 & 368.0 & 365.0 \\
\hline $\mathrm{Ba} / \mathrm{Sr}$ & 0.72 & 0.59 & 0.61 & 0.68 & 1.24 & 1.77 & 1.58 & 0.68 & 1.50 & 1.21 & 1.23 & 0.66 & 0.98 \\
\hline Q & 6.6 & 3.9 & 7.5 & 6.3 & 11.0 & 16.5 & 12.0 & 4.5 & 12.6 & 10.9 & 12.1 & 4.9 & 8.5 \\
\hline Or & 5.5 & 6.7 & 3.5 & 6.6 & 7.3 & 8.8 & 7.8 & 5.3 & 8.5 & 7.3 & 7.5 & 6.0 & 5.9 \\
\hline $\mathrm{Ab}$ & 22.1 & 20.3 & 21.8 & 22.5 & 23.7 & 31.3 & 26.6 & 21.3 & 25.3 & 22.9 & 23.7 & 21.7 & 21.1 \\
\hline An & 38.5 & 37.1 & 38.6 & 38.2 & 25.7 & 17.7 & 20.5 & 37.3 & 24.4 & 25.5 & 30.7 & 36.4 & 31.8 \\
\hline $\mathrm{Ne}$ & 0.0 & 0.0 & 0.0 & 0.0 & 0.0 & 0.0 & 0.0 & 0.0 & 0.0 & 0.0 & 0.0 & 0.0 & 0.0 \\
\hline $\mathrm{Di}$ & 11.6 & 13.8 & 11.9 & 10.2 & 11.6 & 6.6 & 12.0 & 13.4 & 9.7 & 12.2 & 7.9 & 12.9 & 12.5 \\
\hline $\mathrm{Hy}$ & 11.7 & 14.2 & 12.5 & 12.0 & 15.1 & 13.8 & 15.2 & 14.0 & 14.2 & 15.7 & 13.6 & 13.6 & 15.7 \\
\hline OI & 0.0 & 0.0 & 0.0 & 0.0 & 0.0 & 0.0 & 0.0 & 0.0 & 0.0 & 0.0 & 0.0 & 0.0 & 0.0 \\
\hline Mt & 1.5 & 1.5 & 1.6 & 1.5 & 1.9 & 1.8 & 2.0 & 1.6 & 1.8 & 2.0 & 1.6 & 1.7 & 1.7 \\
\hline Il & 1.6 & 1.4 & 1.6 & 1.5 & 2.2 & 2.1 & 2.5 & 1.5 & 2.2 & 2.2 & 1.8 & 1.7 & 1.7 \\
\hline Ap & 0.3 & 0.4 & 0.3 & 0.4 & 0.4 & 0.6 & 0.4 & 0.3 & 0.4 & 0.3 & 0.3 & 0.3 & 0.3 \\
\hline
\end{tabular}

that the nature of the mantle wedge and/or the petrogenetic processes have changed with time. One possibility is that the mantle wedge has become more refractory (i.e., more $\mathrm{Mg}$-rich) and depleted in the high-fieldstrength trace elements, despite being repeatedly replenished by a volatile (lithophile element-rich) fluid or melt phase. In this case, the primitive island-arc tholeiites could represent early melting of the mantle wedge, having essentially the composition of the $\mathrm{N}$-type MORB mantle reservoir enriched in the volatile elements. Such mantle would melt to similar or slightly higher degrees than that feeding mid-ocean ridges. The calc-alkaline magmas would then represent partial melts derived from the re-enriched mantle residue of primitive arc-tholeiite magmatism. Such a refractory mantle is unlikely to melt to such high degrees, and the HYG element composition of the liquids produced would be much more influenced by the composition of the volatile phase producing the re-enrichment. In this model the proportion of the minor titanium phases (sphene or rutile) in the mantle wedge would increase with time; this, together, with a general decrease in the degree of partial melting could explain a general increase in the magnitude of the negative $\mathrm{Ta}$ anomaly with time: the tholeiites from the fore-arc are less depleted in Ta than the other arc lavas (Figs. 22 and 24). The mantle underlying the fore-arc at the present has been cooled sufficiently to preclude subsequent magmatism, and re- 
Table 6. (Continued).

\begin{tabular}{|c|c|c|c|c|c|c|c|c|c|c|c|c|c|}
\hline $\begin{array}{c}\text { MV } \\
15297\end{array}$ & $\begin{array}{c}\text { MV } \\
15304\end{array}$ & $\begin{array}{c}\text { MV } \\
15344\end{array}$ & $\begin{array}{l}\text { MV } \\
1502\end{array}$ & $\begin{array}{l}\text { MV } \\
1504\end{array}$ & $\begin{array}{c}\text { MV } \\
1506\end{array}$ & $\begin{array}{c}\text { MV } \\
1508\end{array}$ & $\begin{array}{l}\text { MV } \\
1515\end{array}$ & $\begin{array}{c}\text { MV } \\
1520\end{array}$ & $\begin{array}{l}\text { MV } \\
1526\end{array}$ & $\begin{array}{c}\text { MV } \\
1580\end{array}$ & $\begin{array}{l}\text { MV } \\
17\end{array}$ & $\begin{array}{c}\text { MV } \\
15132\end{array}$ & $\begin{array}{l}\text { MV } \\
1517\end{array}$ \\
\hline 58.0 & 54.9 & 55.1 & 54.4 & 52.3 & 59.6 & 57.3 & 54.8 & 52.0 & 55.4 & 59.7 & 54.0 & 60.5 & 52.5 \\
\hline 0.95 & 0.89 & 1.00 & 0.71 & 0.80 & 0.98 & 1.14 & 1.26 & 0.71 & 0.88 & 1.10 & 0.98 & 1.11 & 0.93 \\
\hline 15.4 & 16.7 & 17.0 & 20.5 & 19.2 & 14.9 & 13.7 & 14.8 & 19.3 & 18.6 & 13.4 & 15.4 & 13.9 & 15.7 \\
\hline 9.62 & 9.87 & 9.83 & 8.00 & 8.75 & 9.72 & 10.53 & 9.79 & 8.14 & 7.99 & 9.85 & 10.88 & 9.82 & 10.51 \\
\hline 0.18 & 0.16 & 0.15 & 0.12 & 0.13 & 0.18 & 0.17 & 0.14 & 0.12 & 0.11 & 0.19 & 0.18 & 0.19 & 0.17 \\
\hline 2.52 & 3.82 & 2.81 & 3.17 & 2.87 & 2.63 & 2.90 & 3.54 & 3.58 & 3.44 & 2.00 & 3.28 & 1.90 & 2.85 \\
\hline 7.08 & 9.40 & 8.92 & 11.13 & 10.27 & 6.38 & 6.81 & 8.72 & 10.88 & 9.67 & 5.14 & 8.37 & 5.21 & 8.70 \\
\hline 3.21 & 2.47 & 2.70 & 2.66 & 2.39 & 3.27 & 2.85 & 2.17 & 2.37 & 3.50 & 3.49 & 2.56 & 3.67 & 2.66 \\
\hline 1.20 & 1.04 & 1.03 & 0.69 & 1.30 & 1.33 & 1.31 & 1.49 & 1.18 & 1.17 & 1.48 & 1.32 & 1.48 & 1.26 \\
\hline 0.18 & 0.13 & 0.12 & 0.16 & 0.17 & 0.17 & 0.14 & 0.17 & 0.16 & 0.22 & 0.22 & 0.16 & 0.23 & 0.15 \\
\hline 98.40 & 99.31 & 98.70 & 101.53 & 98.22 & 99.20 & 96.86 & 96.85 & 98.48 & 100.97 & 96.58 & 97.18 & 98.02 & 95.42 \\
\hline 2 & 13 & 4 & $<1$ & 3 & $<1$ & 3 & 12 & 28 & 3 & $<1$ & 1 & $<1$ & 2 \\
\hline 10 & 34 & 11 & 7 & 8 & 3 & 6 & 37 & 65 & 11 & $<1$ & 8 & $<1$ & 5 \\
\hline 90 & 95 & 85 & 58 & 70 & 98 & 92 & 82 & 66 & 48 & 121 & 97 & 112 & 104 \\
\hline 13 & 16 & 16 & 17 & 20 & 15 & 14 & 16 & 19 & 19 & 16 & 17 & 15 & 18 \\
\hline 26 & 26 & 23 & 35 & 35 & 27 & 31 & 36 & 33 & 18 & 32 & 32 & 31 & 33 \\
\hline 364 & 392 & 374 & 509 & 568 & 355 & 324 & 359 & 512 & 467 & 350 & 432 & 350 & 430 \\
\hline 30 & 22 & 24 & 17 & 22 & 35 & 31 & 31 & 19 & 20 & 39 & 23 & 38 & 24 \\
\hline 82 & 70 & 77 & 55 & 90 & 91 & 92 & 107 & 77 & 71 & 103 & 83 & 104 & 81 \\
\hline$<1$ & $<1$ & $<1$ & $<1$ & $<1$ & $<1$ & $<1$ & $<1$ & $<1$ & 2 & $<1$ & 2 & $<1$ & $<1$ \\
\hline 500 & 395 & 414 & 215 & 339 & 562 & 574 & 612 & 265 & 326 & 644 & 394 & 644 & 398 \\
\hline 15 & 14 & 12 & 9 & 18 & 16 & 16 & 21 & 12 & 12 & 21 & 17 & 20 & 16 \\
\hline 37 & 29 & 33 & 24 & 40 & 39 & 38 & 46 & 31 & 29 & 41 & 38 & 45 & 34 \\
\hline 20 & 16 & 16 & 12 & 21 & 22 & 21 & 23 & 18 & 15 & 24 & 19 & 25 & 18 \\
\hline 9 & 8 & $<1$ & 4 & 4 & 5 & 8 & 15 & 5 & $<1$ & 6 & 14 & 7 & 6 \\
\hline 7 & 8 & 2 & 5 & 7 & 4 & 6 & 9 & 3 & 7 & 10 & 8 & 6 & 6 \\
\hline$>82.0$ & $>70.0$ & $>77.0$ & $>55.0$ & $>90.0$ & $>91.0$ & $>92.0$ & $>107.0$ & $>77.0$ & 35.0 & $>103.0$ & 41.0 & $>104.0$ & $>81.0$ \\
\hline 69.0 & 76.0 & 78.0 & 77.0 & 53.0 & 65.0 & 74.0 & 71.0 & 55.0 & 74.0 & 64.0 & 71.0 & 64.0 & 69.0 \\
\hline 0.37 & 0.31 & 0.31 & 0.31 & 0.24 & 0.38 & 0.34 & 0.29 & 0.25 & 0.28 & 0.38 & 0.28 & 0.37 & 0.30 \\
\hline 0.45 & 0.41 & 0.43 & 0.44 & 0.44 & 0.43 & 0.41 & 0.43 & 0.40 & 0.41 & 0.40 & 0.46 & 0.43 & 0.42 \\
\hline 6.10 & 5.64 & 5.38 & 3.91 & 3.77 & 6.18 & 6.24 & 5.72 & 3.44 & 4.59 & 6.25 & 4.75 & 6.19 & 4.91 \\
\hline 3.03 & 3.24 & 3.38 & 3.47 & 4.47 & 2.74 & 3.01 & 3.64 & 4.01 & 3.56 & 2.58 & 4.06 & 2.91 & 3.48 \\
\hline 4.43 & 3.00 & 4.06 & 2.93 & 3.54 & 4.29 & 4.21 & 3.21 & 2.64 & 2.69 & 5.71 & 3.85 & 5.99 & 4.28 \\
\hline 383.0 & 332.0 & 372.0 & 164.0 & 308.0 & 409.0 & 351.0 & 344.0 & 297.0 & 540.0 & 384.0 & 342.0 & 396.0 & 317.0 \\
\hline 1.37 & 1.01 & 1.11 & 0.42 & 0.60 & 1.58 & 1.77 & 1.70 & 0.52 & 0.70 & 1.84 & 0.91 & 1.84 & 0.93 \\
\hline 13.2 & 8.6 & 9.8 & 6.2 & 5.3 & 14.8 & 14.4 & 11.5 & 4.1 & 4.1 & 17.1 & 8.7 & 16.7 & 7.3 \\
\hline 7.2 & 6.2 & 6.2 & 4.0 & 7.8 & 7.9 & 8.0 & 9.1 & 7.1 & 6.8 & 9.1 & 8.0 & 8.9 & 7.8 \\
\hline 27.6 & 21.0 & 23.1 & 22.2 & 20.6 & 27.9 & 24.9 & 19.0 & 20.4 & 29.3 & 30.6 & 22.3 & 31.7 & 23.6 \\
\hline 24.6 & 31.5 & 31.6 & 41.3 & 38.6 & 22.3 & 21.4 & 27.1 & 39.1 & 31.2 & 17.2 & 27.5 & 17.3 & 28.5 \\
\hline 0.0 & 0.0 & 0.0 & 0.0 & 0.0 & 0.0 & 0.0 & 0.0 & 0.0 & 0.0 & 0.0 & 0.0 & 0.0 & 0.0 \\
\hline 8.6 & 12.4 & 10.6 & 10.2 & 10.4 & 7.3 & 10.7 & 13.9 & 12.3 & 12.5 & 6.8 & 12.1 & 6.6 & 13.5 \\
\hline 14.0 & 15.7 & 13.8 & 12.4 & 13.0 & 14.9 & 15.2 & 14.0 & 13.2 & 11.7 & 14.0 & 16.2 & 13.5 & 14.3 \\
\hline 0.0 & 0.0 & 0.0 & 0.0 & 0.0 & 0.0 & 0.0 & 0.0 & 0.0 & 0.0 & 0.0 & 0.0 & 0.0 & 0.0 \\
\hline 1.7 & 1.7 & 1.7 & 1.4 & 1.5 & 1.7 & 1.9 & 1.8 & 1.4 & 1.4 & 1.8 & 1.9 & 1.7 & 1.9 \\
\hline 1.8 & 1.7 & 1.9 & 1.3 & 1.5 & 1.9 & 2.2 & 2.5 & 1.4 & 1.7 & 2.2 & 1.9 & 2.2 & 1.9 \\
\hline 0.4 & 0.3 & 0.3 & 0.4 & 0.4 & 0.4 & 0.3 & 0.4 & 0.4 & 0.5 & 0.5 & 0.4 & 0.6 & 0.4 \\
\hline
\end{tabular}

Table 7. INA trace element analyses (ppm) of 15 andesites from the Mariana arc.

\begin{tabular}{|c|c|c|c|c|c|c|c|c|c|c|c|c|c|c|c|c|c|c|c|c|c|c|c|}
\hline $\begin{array}{l}\text { Sample } \\
\text { Number }\end{array}$ & $\mathrm{Sc}$ & $\mathrm{Cr}$ & Co & $\mathrm{Ni}$ & $\mathrm{Rb}$ & $\mathrm{Sr}$ & $\mathrm{Zr}$ & Cs & $\mathrm{Ba}$ & $\mathrm{La}$ & $\mathrm{Ce}$ & Eu & $\mathrm{Tb}$ & Hf & $\mathrm{Ta}$ & Th & U & $\mathrm{La} / \mathrm{Ta}$ & $\mathrm{La} / \mathrm{Th}$ & $\mathrm{La} / \mathrm{Tb}$ & Th/Hf & $\mathrm{Ba} / \mathrm{La}$ & $\mathrm{La} / \mathrm{Ce}$ \\
\hline RD17 & 29.8 & 60 & 27.2 & 8 & 30.4 & 431 & 92 & 0.68 & 404 & 17.4 & 29.9 & 1.38 & 0.69 & 2.16 & 0.11 & 2.67 & 0.76 & 158 & 6.5 & 25.2 & 1.2 & 23.2 & 0.58 \\
\hline MV1502 & 23.8 & 47 & 19.5 & 6 & 29.6 & 502 & 66 & 1.73 & 2.19 & 9.4 & 16.2 & 1.14 & 0.44 & 1.27 & 0.06 & 1.23 & 0.39 & 157 & 7.6 & 21.4 & 1.0 & 23.3 & 0.58 \\
\hline MV1504 & 23.4 & 49 & 20.1 & 7 & 30.6 & 551 & 108 & 0.59 & 371 & 19.4 & 30.6 & 1.45 & 0.63 & 2.19 & 0.11 & 2.66 & 0.83 & 176 & 7.3 & 30.8 & 1.2 & 19.1 & 0.63 \\
\hline MV1508 & 27.2 & 53 & 20.6 & 8 & 25.6 & 307 & 88 & 0.82 & 557 & 16.6 & 27.9 & 1.34 & 0.78 & 2.68 & 0.14 & 2.71 & 0.78 & 119 & 6.1 & 21.3 & 1.0 & 33.6 & 0.60 \\
\hline MV1515 & 28.4 & 74 & 21.6 & 16 & 31.0 & 355 & 134 & 1.05 & 627 & 20.2 & 32.8 & 1.37 & 0.77 & 2.87 & 0.17 & 3.61 & 1.00 & 119 & 5.6 & 26.2 & 1.3 & 31.0 & 0.62 \\
\hline MV1520 & 23.6 & 99 & 23.2 & 36 & 30.4 & 508 & 106 & 0.47 & 298 & 15.7 & 27.7 & 1.45 & 0.58 & 2.15 & 0.11 & 2.00 & 0.64 & 143 & 7.9 & 27.1 & 0.9 & 19.0 & 0.57 \\
\hline MV1526 & 28.7 & 49 & 25.5 & 8 & 15.1 & 441 & 94 & 0.12 & 302 & 14.0 & 22.2 & 1.32 & 0.58 & 1.79 & 0.09 & 1.74 & 0.61 & 156 & 8.0 & 24.1 & 1.0 & 21.6 & 0.63 \\
\hline MV1580 & 24.4 & 47 & 16.4 & 0.5 & 30.8 & 343 & 136 & 0.89 & 626 & 20.5 & 33.6 & 1.69 & 0.99 & 3.02 & 0.15 & 3.08 & 0.86 & 137 & 6.7 & 20.7 & 1.0 & 30.5 & 0.61 \\
\hline MV15101 & 30.3 & 62 & 26.7 & 8 & 25.3 & 392 & 114 & 0.63 & 462 & 15.2 & 30.9 & 1.36 & 0.70 & 2.40 & 0.13 & 2.46 & 0.62 & 117 & 6.2 & 21.7 & 1.0 & 30.4 & 0.49 \\
\hline MV15117 & 24.8 & 48 & 16.4 & 0 & 29.3 & 349 & 126 & 0.86 & 613 & 19.5 & 33.2 & 1.72 & 0.96 & 3.03 & 0.15 & 3.03 & 0.87 & 130 & 6.4 & 20.3 & 1.0 & 31.4 & 0.59 \\
\hline MV15132 & 24.6 & 47 & 16.6 & 0.7 & 29.9 & 339 & 112 & 0.87 & 626 & 19.9 & 33.5 & 1.69 & 0.97 & 2.99 & 0.16 & 3.02 & 0.86 & 124 & 6.6 & 20.5 & 1.0 & 31.5 & 0.59 \\
\hline MV15146 & 32.2 & 66 & 27.7 & 9 & 27.0 & 340 & 89 & 0.78 & 527 & 16.4 & 27.7 & 1.49 & 0.83 & 2.69 & 0.13 & 2.65 & 0.67 & 126 & 6.2 & 19.8 & 1.0 & 32.1 & 0.59 \\
\hline MV15220 & 31.4 & 65 & 26.9 & 9 & 23.5 & 389 & 96 & 0.68 & 482 & 16.1 & 27.6 & 1.40 & 0.73 & 2.42 & 0.12 & 2.55 & 0.72 & 134 & 6.3 & 22.1 & 1.1 & 29.9 & 0.58 \\
\hline MV1801 & 24.5 & 53 & 22.3 & 10 & 18.4 & 468 & 70 & 0.48 & 322 & 11.5 & 18.6 & 1.14 & 0.49 & 1.76 & 0.09 & 1.75 & 0.49 & 128 & 6.6 & 23.5 & 1.0 & 28.0 & 0.62 \\
\hline MV1802 & 24.7 & 134 & 25.0 & 46 & 25.7 & 487 & 93 & 0.49 & 278 & 14.6 & 25.6 & 1.42 & 0.56 & 1.91 & 0.08 & 1.76 & 0.58 & 183 & 8.3 & 26.1 & 0.9 & 19.0 & 0.57 \\
\hline
\end{tabular}

Note: Samples from P. Fryer; sample designations as in Table 6. 


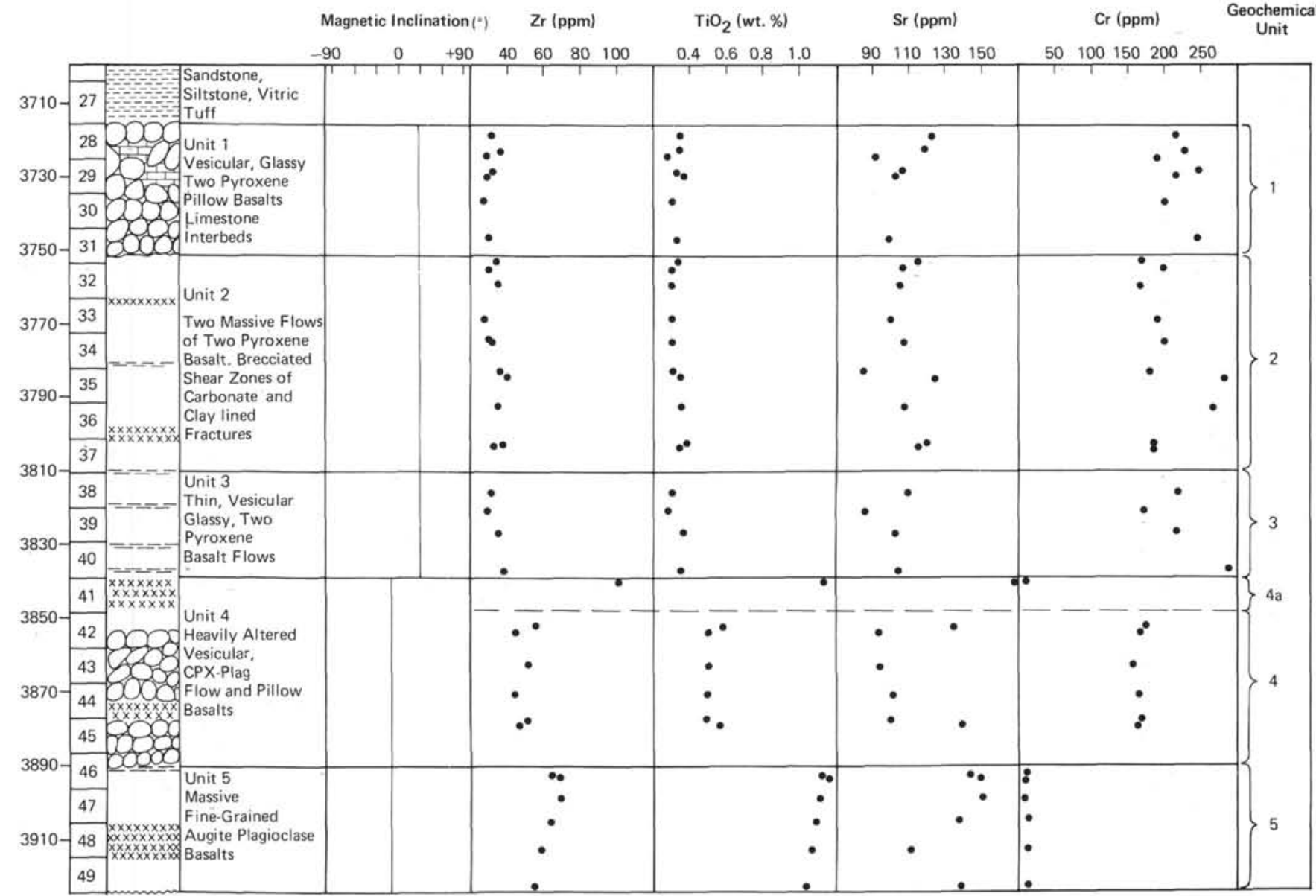

Figure 14. Geochemical and lithological stratigraphy of the basement sections of Hole 458 .

cent arc magmatism has become restricted to a zone above the steeply dipping Benioff zone.

The possible coexistence of N-type MORB and calcalkaline magmas in the initial period of inter-arc basin formation, as observed in the Mariana Trough (Sites 454 and 456), might be expected from this model. The general absence of basalts with calc-alkaline affinities in the Parece-Vela Basin and Shikoku Basin implies that the influence of the arc mantle sources disappears once the basins are well developed.

\section{ACKNOWLEDGMENTS}

The analytical work was carried out with financial support from the Natural Environment Research Council (NERC), U.K. and the Centre National de la Recherche Scientifique, France. DAW and NGM gratefully acknowledge NERC fellowships supporting work on samples recovered by DSDP. We thank Drs. J. H. Natland, J. A. Pearce, and A. D. Saunders for their reviews and comments on the manuscript.

\section{REFERENCES}

Abbotts, I. L., 1979. A field petrological and geochemical study of the Masirah Ophiolite, Oman [Ph.D. dissert.]. University of Birmingham, U.K

Anonymous, 1977. Initial report of the geological study of oceanic crust of the Philippine Sea floor. Ofioliti, 2:137-168.

Barazangi, M., Pennington, W., and Isacks, B. L., 1975. Global study of seismic wave attenuation in the upper mantle behind island arcs using P waves. J. Geophys. Res., 80:1078-1092.
Barker, P. F., 1972. A spreading centre in the East Scotia Sea. Earth Planet. Sci. Lett., 15:123-321.

Best, M. G., 1975. Migration of hydrous fluids in the upper mantle and potassium variation in calc-alkalic rocks. Geology, 3: 429-432.

Cameron, W. E., Nisbet, E. G., and Dietrich, V. J., 1979. Boninites, komatiites and ophiolitic basalts. Nature, 280:550-553.

Chayla, B., Jaffrezic, H., and Joron, J.-L., 1973. Analyse par activation dans les mentions épithermiques. Application à la determination d'éléments en trace dans les roches. Comptes Rendus Acad. Sci. Paris, 277:273-275.

Chow, T. J., Stern, R. J., and Dixon, T. H., 1980. Absolute and relative abundances of $\mathrm{K}, \mathrm{Rb}, \mathrm{Sr}$ and $\mathrm{Ba}$ in circum-Pacific island-arc magmas, with special reference to the Marianas. Chem. Geol., 28:111-121.

Cloud, P. E., Jr., Schmidt, R. G., and Burke, H. W., 1956. Geology of Saipan, Mariana Islands. U.S. Geol. Surv. Prof. Paper, 280A

Dallwitz, W. B., 1968. Chemical composition and genesis of clinoenstatite-bearing volcanic rocks from Cape Vogel, Papua: a discussion. Rept. 23rd Int. Geol. Congr., 2:229-242.

Dallwitz, W. B., Green, D. H., and Thompson, I. E., 1966. Clinoenstatite in a volcanic rock from Cape Vogel, Papua. J. Petrol., 7: 375-403.

DePaolo, D. J., and Wasserburg, C. J., 1977. The sources of island arcs as indicated by $\mathrm{Nd}$ and $\mathrm{Sr}$ isotopic studies. Geophys. Res. Lett., 4:465-468.

Dietrich, V., Emmermann, R., Oberhansli, R., et al., 1978. Geochemistry of basaltic and gabbroic rocks from the west Mariana basin and the Mariana Trench. Earth Planet. Sci. Lett., 39:127-144.

Dixon, T. H., and Batiza, R., 1979. Petrology and chemistry of recent lavas in the Northern Marianas: Implications for the origin of island arc basalts. Contrib. Mineral. Petrol., 70:167-181. 
Garcia, M. O., Liu, N. W. K., and Muenow, D. W., 1979. Volatiles in submarine volcanic rocks from the Mariana Island arc and trough. Geochim. Cosmochim. Acta, 43:305-312.

Gill, J. B., 1976. Composition and age of Lau Basin and Ridge volcanic rocks: implications for evolution of an interarc basin and remnant arc. Geol. Soc. Am. Bull., 87:1384-1395.

Green, D. H., 1976. Experimental testing of "equilibrium" partia melting of peridotite under water-saturated, high pressure conditions. Can. Mineralogists, 14:255-268.

Hart, S. R., Glassley, W. E., and Karig, D. E., 1972. Basalts and sea floor spreading behind the Mariana Island arc. Earth Planet. Sci. Lett., 15:12-18.

Hawkesworth, C. J., O'Nions, R. K., Pankhurst, R. J., et al., 1978. A geochemical study of island arc and back-arc tholeiites from the Scotia Sea. Earth Planet. Sci. Lett., 36:253-262.

Hawkins, J. W., 1974. Geology of the Lau Basin, a marginal basin behind the Tonga Arc. In Burke, C. A., and Drake, C. L. (Eds.), The Geology of Continental Margins: New York (Springer), pp. 505 520 .

1976. Petrology and geochemistry of basaltic rocks of the Lau Basin. Earth Planet. Sci. Lett., 28:283-297.

1977. Petrology and geochemical characteristics of marginal basin basalts. In Talwani, M., and Pitman III, W. C. (Eds.), Island Arcs, Deep Sea Trenches and Back-Arc Basins: Maurice Ewing Series 1: Washington (American Geophysical Union), 355-365.

Hellman, P. L., and Green, T. H., 1979. The role of sphene as an accessory phase in the high pressure partial melting of hydrous mafic compositions. Earth Planet. Sci. Lett., 42:191-201.

Hickey, R., and Frey, F. A., 1979. Petrogenesis of high-Mg andesites: Geochemical evidence. EOS, 60:413.

Hussong, D. H., Uyeda, S., et al., 1978. Near the Philippines-Leg 60 ends in Guam. Geotimes, 23(10):19-22.

Isacks, B. L., and Barazangi, M., 1977. Geometry of Benioff zones: Lateral segmentation and downwards bending of the subducted lithosphere. In Talwani, M., and Pitman III, W. C. (Eds.), Island Arcs, Deep Sea Trenches and Back-Arc Basins: Maurice Ewing Series 1: Washington (American Geophysical Union).

Karig, D. E., 1971. Origin and development of marginal basins in the western Pacific. J. Geophys. Res., 76:2542-2561.

Karig, D. E., Anderson, R. N., and Bibee, L. D., 1978. Characteristics of back arc spreading in the Mariana Trough. J. Geophys. Res., $83: 1213-1226$.

Katsumata, M., and Sykes, L. R., 1969. Seismicity and tectonics of the western Pacific: Izu-Mariana-Caroline and Ryuku-Taiwan region. J. Geophys. Res., 74:5923-5948.

Kuno, H., 1968. Differentiation of basalt magmas. In Hess, H. H., and Poldervaart, A. (Eds.), Basalts (Vol. 2): New York (Wiley), 623-688.

Kuroda, M., and Shiraki, K., 1975. Boninite and related rocks of Chichi-Jima, Bonin Islands. Japan Rep. Fac. Sci. Shizuoka Univ., 10:145-155.

Kuroda, M., Shiraki, K., and Urano, H., 1978. Boninite as a possible calc-alkalic primary magma. Proc. Tokyo Conf., pp. 280-281.

Marsh, N. G., 1977. The geochemistry of plutonic rocks from Atacama Province, North Chile [M.Sc. thesis]. University of Birmingham, U.K.

Marsh, N. G., Saunders, A. D., and Tarney, J., 1980. Geochemistry of basalts from the Shikoku and Daito Basins, DSDP Leg 58. In Klein, G. deV., Kobayashi, K., et al., Init. Repts. DSDP, 58: Washington (U.S. Govt. Printing Office), 805-842.

Mattey, D. P., Marsh, N. G., and Tarney, J., 1980. The geochemistry, mineralogy and petrology of igneous rocks from the West Philippine and Parece Vela Basins, and from the Kyushu-Palau and West Mariana Ridges, IPOD Leg 59. In Kroenke, L., Scott, R., et al., Init. Repts. DSDP, 59: Washington (U.S. Govt. Printing Office), 753-800.

Meijer, A., 1976. $\mathrm{Pb}$ and $\mathrm{Sr}$ isotopic data bearing on the origin of volcanic rocks from the Mariana island arc system. Bull. Geol. Soc. Am., 87:1358-1369.

Moore, J., and Schilling, J-G., 1973. Vesicles, water and sulfur in Rejkjanes Ridge basalts. Contrib. Mineral. Petrol., 41:105-118.

Murauchi, S., Den, N., Asaro, S., et al., 1968. Crustal structure of the Philippine Sea. J. Geophys. Res., 73:3143-3171.
Pearce, J. A., in press. Geochemical evidence for the genesis and eruptive setting of lavas from Tethyan Ophiolites. Proc. Symp. on Ophiolite Problems. Geol. Survey Cyprus.

Philpotts, J. A., Martin, W., and Schnetzler, C. C., 1971. Geochemical aspects of some Japanese lavas. Earth Planet. Sci. Lett., 12:89-95.

Poehls, K. A., 1978. Inter-arc basins: a kinematic model. Geophys. Res. Lett., 5:325-328.

Rhodes, J. M., Dungan, M. A., Blanchard, D. P., et al., 1979. Magma mixing at mid-ocean ridges: evidence from basalts drilled near $22^{\circ} \mathrm{N}$ on the mid-Atlantic Ridge. Tectonophysics, 55:35-61

Ringwood, A. E., 1974. The petrological evolution of island arc systems. J. Geol. Soc. London, 130:183-204.

Saunders, A. D., and Tarney, J., 1979. The geochemistry of basalts from a back-arc spreading centre in the East Scotia Sea. Geochim. Cosmochim. Acta, 43:555-572.

Saunders, A. D., Tarney, J., and Weaver, S. D., 1980. Transverse geochemical variations across the Antarctic Peninsula: Implications for the genesis of calc-alkalic magmas. Earth Planet. Sci. Lett., 46:344-360.

Schmidt, R. G., 1957. Geology of Saipan, Mariana Islands, Chapter B. Petrology of the volcanic rocks. U.S. Geol. Surv. Prof. Paper, 280B:127-175.

Sclater, J. G., Hawkins, J. W., Mammerickx, J., et al., 1972. Crustal extension between the Tonga and Low Ridges: petrologic and geophysical evidence. Bull. Geol. Soc. Am., 83:505-517.

Scott, R. B., Kroenke, L., et al., 1980. Init. Repts. DSDP, 59: Washington (U.S. Govt. Printing Office).

Sharaskin, A. Ya, Dobretsov, N. L., and Sobolev, N. V., in press. Marianites: the clinoenstatite bearing pillow lavas associated with ophiolite assemblage of the Mariana Trench. Proc. Int. Ophiolite Symp. Cyprus.

Shiraki, K., Kuroda, N., and Urano, H., 1979. Clinoenstative-bearing boninite of Muko-jima, Bonin Islands. J. Geol. Soc. Japan, $85: 591-594$.

Stark, J. T., 1963. Petrology of the volcanic rocks of Guam. U.S. Geol. Surv. Prof. Paper. 403C, 32.

Stern, R. J., 1979. On the origin of andesite in the northern Mariana Island Arc: Implications from Agrigan. Contrib. Mineral. Petrol., $68: 207-219$

Sun, S-S., 1980. Lead isotopic study of young volcanic rocks from mid-ocean ridges, ocean islands and island arcs. Philos. Trans. Roy. Soc. Lond. Ser. A., 297:409-445.

Sun, S-S., and Nesbitt, R. W., 1978. Geochemical regularities and genetic significance of ophiolitic basalts. Geology, 6:689-693.

Sun, S-S., Nesbitt, R. W., and Sharaskin, A. Y., 1979. Chemical characteristics of mid-ocean ridge basalts. Earth Planet. Sci. Lett., 44:119-138.

Tarney, J., Saunders, A. D., and Weaver, S. D., 1977. Geochemistry of volcanic rocks from the island arcs and marginal basins of Scotia Arc region. In Talwani, M., and Pitman III, W. C. (Eds.), Island Arcs, Deep Sea Trenches and Back-Arc Basins: Maurice Ewing Series, 1: Washington (American Geophysical Union), 367-377.

Tarney, J., Saunders, A. D., Weaver, S. D., Donnellan, N. C. B., and Hendry, G. L., 1978. Minor element chemistry of basalts from Leg 49, North Atlantic Ocean. In Luyendyk, B. P., Cann, J. R., et al., Init. Repts. DSDP, 49: Washington (U.S. Govt. Printing Office), 567-691.

Tarney, J. Wood, D. A., Saunders, A. D., et al., 1980. Nature of mantle heterogeneity in the North Atlantic: evidence from deep sea drilling. Philos. Trans. Roy. Soc. Lond. Ser. A., 297:179-202.

Taylor, S. R., Capp, A. C., Graham, A. L., et al., 1969. Trace element abundances in andesite 11. Saipan, Bougainville and Fiji. Contr. Mineral. Petrol., 23:1-26.

Treuil, M., and Varet, J., 1973. Critères volcanologiques, pétrologiques et géochimiques de la genèse et de la différentiation des magmas basaltiques: exemple de l'Afar. Bull. Soc. Geol. France, $15: 506-540$.

Uyeda, S., and Kanamori, H., 1979. Back-arc opening and the mode of subduction. J. Geophys. Res., 84:1049-1061.

Vogt, P. R., Lowrie, A., Bracey, D. R., et al., 1976. Subduction of aseismic ocean ridges: Effects on shape, seismicity, and other characteristics of consuming plate boundaries. Geol. Soc. Am. Special Paper 172. 
Weaver, S. D., Saunders, A. D., Pankhurst, R. J., et al., 1979. A geochemical study of magmatism associated with the initial stages of back-arc spreading: the Quaternary volcanics of Bransfield Strait, South Shetland Islands. Contr. Mineral. Petrol., 68:151-169.

Weaver, S. D., Sceal, J. S. C., and Gibson, I. L., 1972. Trace element data relevant to the origin of trachytic and pantelleritic lavas in the East African Rift System. Contrib. Mineral. Petrology, 36:181190.

Wells, P. 1978. The geochemistry of the Patagonia batholith between $45^{\circ} \mathrm{S}$ and $46^{\circ} \mathrm{S}$ latitude [M.Sc. thesis]. University of Birmingham, U.K. (unpublished).

Wood, D. A., 1979. A variably veined sub-oceanic upper mantle: genetic significance for mid-ocean ridge basalts from geochemical evidence. Geology, 7:499-503.

, 1980. The application of a Th-Hf-Ta diagram to problems of tectonomagmatic classification and to establishing the nature of crustal contamination of basaltic lavas of the British Tertiary Volcanic Province. Earth Planet. Sci. Lett., 50:11-30.
Wood, D. A., Joron, J. L., Marsh, N. G., et al., 1980a. Major and trace element variations in basalts from the North Philippine Sea drilled during DSDP Leg 58: A comparative study of back-arc basin basalt with lava series from Japan and mid-ocean ridges. In Klein, G. deV., Kobayashi, K., et al., Init. Repts. DSDP, 58: Washington (U.S. Govt. Printing Office), 873-894.

Wood, D. A., Joron, J. L., and Treuil, M., 1979b. A re-appraisal of the use of trace elements to classify and discriminate between magma series in different tectonic settings. Earth Planet. Sci. Lett., 45:326-336.

Wood, D. A., Mattey, D. P., Joron, J. L., et al., 1980a. A geochemical study of 17 selected samples from the basement cores recovered at Sites $447,448,449,450$, and 451 DSDP Leg 59. In Kroenke, L., Scott, R., et al., Init. Repts. DSDP, 59: Washington (U.S. Govt. Printing Office), 743-752.

Wood, D. A., Tarney, J., Varet, J., et al., 1979a. Geochemistry of basalts drilled in the North Atlantic by IPOD Leg 49: implications for mantle heterogeneity. Earth Planet. Sci. Lett., 42:77-97. 
Table 8. Major and trace element analyses of igneous rocks from Hole 458.

\begin{tabular}{|c|c|c|c|c|c|c|c|c|c|c|c|c|c|c|c|c|c|}
\hline $\begin{array}{c}\text { Sample } \\
\text { (interval } \\
\text { in } \mathrm{cm} \text { ) }\end{array}$ & $\begin{array}{c}27-1 \\
130-132\end{array}$ & $\begin{array}{l}28-1 \\
58-60\end{array}$ & $\begin{array}{c}28-1 \\
125-127\end{array}$ & $\begin{array}{l}28-1 \\
140-142\end{array}$ & $\begin{array}{l}29-1 \\
54-60\end{array}$ & $\begin{array}{l}29-2 \\
37-39\end{array}$ & $\begin{array}{l}30-1 \\
56-58\end{array}$ & $\begin{array}{l}31-1 \\
39-41\end{array}$ & $\begin{array}{c}31-1 \\
131-133\end{array}$ & $\begin{array}{c}32-1 \\
116-118\end{array}$ & $\begin{array}{l}32-3 \\
34-36\end{array}$ & $\begin{array}{l}33-2 \\
19-21\end{array}$ & $\begin{array}{l}34-1 \\
34-41\end{array}$ & $\begin{array}{l}35-1 \\
42-44\end{array}$ & $\begin{array}{l}35-2 \\
69-71\end{array}$ & $\begin{array}{c}36-1 \\
27-29\end{array}$ & $\begin{array}{l}37-1, \\
52-54\end{array}$ \\
\hline $\mathrm{SiO}_{2}$ & 54.6 & 52.5 & 52.8 & 56.1 & 53.1 & 52.0 & 51.5 & 53.2 & 57.1 & 58.8 & 59.0 & 56.9 & 59.8 & 53.3 & 52.4 & 52.4 & \\
\hline $\mathrm{TiO}_{2}$ & 0.15 & 0.34 & 0.34 & 0.28 & 0.33 & 0.36 & 0.30 & 0.33 & 0.33 & 0.30 & 0.30 & 0.30 & 0.30 & 0.30 & 0.35 & 0.35 & 0.37 \\
\hline $\mathrm{Al}_{2} \mathrm{O}_{3}$ & 7.9 & 18.0 & 18.3 & 13.7 & 15.4 & 14.4 & 17.8 & 16.1 & 15.2 & 14.2 & 13.9 & 13.2 & 14.7 & 13.8 & 16.5 & 15.1 & 15.1 \\
\hline $\mathrm{TFe}_{2} \mathrm{O}_{3}$ & 11.92 & 9.31 & 8.55 & 9.32 & 9.16 & 10.23 & 9.36 & 9.24 & 9.38 & 9.32 & 9.34 & 8.98 & 8.95 & 8.75 & 9.20 & 10.13 & 9.36 \\
\hline $\mathrm{MnO}$ & 0.42 & 0.11 & 0.11 & 0.14 & 0.10 & 0.12 & 0.17 & 0.10 & 0.11 & 0.10 & 0.11 & 0.12 & 0.12 & 0.11 & 0.12 & 0.14 & 0.10 \\
\hline $\mathrm{MgO}$ & 16.35 & 5.09 & 5.35 & 6.11 & 8.97 & 9.71 & 6.32 & 7.47 & 5.19 & 5.02 & 4.62 & 8.13 & 5.53 & 5.23 & 7.12 & 8.73 & 7.63 \\
\hline $\mathrm{CaO}$ & 1.83 & 11.17 & 11.32 & 9.59 & 9.26 & 8.70 & 7.99 & 9.49 & 10.45 & 9.60 & 9.24 & 8.93 & 10.76 & 9.74 & 9.76 & 7.90 & 10.13 \\
\hline $\mathrm{Na}_{2} \mathrm{O}$ & 2.67 & 2.77 & 2.67 & 1.97 & 2.60 & 2.63 & 3.13 & 2.65 & 2.81 & 2.36 & 2.50 & 2.24 & 2.61 & 2.33 & 2.81 & 3.04 & 2.87 \\
\hline $\mathrm{K}_{2} \mathrm{O}$ & 1.64 & 0.63 & 0.96 & 0.44 & 1.23 & 0.88 & 1.53 & 1.12 & 0.85 & 1.20 & 1.16 & 0.61 & 1.12 & 0.83 & 0.79 & 1.05 & 1.38 \\
\hline $\mathrm{P}_{2} \mathrm{O}_{5}$ & 0.00 & 0.03 & 0.02 & 0.02 & 0.01 & 0.01 & 0.01 & 0.01 & 0.05 & 0.04 & 0.04 & 0.03 & 0.04 & 0.04 & 0.01 & 0.01 & 0.05 \\
\hline Total & 97.45 & 99.97 & 100.41 & 97.70 & 100.13 & 99.01 & 98.17 & 99.73 & 101.48 & 100.94 & 100.24 & 101.73 & 101.02 & 100.97 & 99.93 & 98.88 & 99.40 \\
\hline $\mathrm{Ni}$ & 315 & 80 & 79 & 74 & 91 & 76 & 81 & 73 & 56 & 59 & 59 & 67 & 65 & 60 & 101 & 97 & 62 \\
\hline $\mathrm{Cr}$ & 1303 & 214 & 229 & 189 & 244 & 216 & 201 & 245 & 168 & 199 & 168 & 191 & 200 & 181 & 282 & 267 & 184 \\
\hline $\mathrm{Zn}$ & 57 & 71 & 64 & 54 & 74 & 76 & 55 & 65 & 48 & 50 & 48 & 52 & 52 & 55 & 76 & 73 & 57 \\
\hline $\mathrm{Ga}$ & 5 & 14 & 15 & 14 & 17 & 15 & 9 & 11 & 14 & 16 & 14 & 15 & 15 & 14 & 17 & 13 & 16 \\
\hline $\mathrm{Rb}$ & 21 & 7 & 7 & 8 & 13 & 5 & 11 & 9 & 46 & 61 & 113 & 13 & 24 & 13 & 8 & 5 & 33 \\
\hline $\mathrm{Sr}$ & 55 & 122 & 119 & 92 & 106 & 103 & 69 & 99 & 116 & 106 & 105 & 100 & 107 & 85 & 124 & 107 & 119 \\
\hline$Y$ & $<1$ & 8 & 6 & 7 & 3 & 2 & 5 & 2 & 8 & 6 & 8 & 6 & 9 & 12 & 3 & 5 & 12 \\
\hline $\mathrm{Zr}$ & 24 & 31 & 36 & 28 & 31 & 30 & 27 & 30 & 33 & 30 & 35 & 28 & 30 & 36 & 39 & 34 & 36 \\
\hline $\mathrm{Nb}$ & 2 & $<1$ & $<1$ & 2 & $<1$ & $<1$ & $<1$ & $<1$ & $<1$ & $<1$ & $<1$ & $<1$ & $<1$ & $<1$ & $<1$ & $<1$ & $<1$ \\
\hline $\mathrm{Ba}$ & 59 & 41 & 22 & 33 & 13 & 15 & 54 & 6 & 35 & 49 & 29 & 51 & 47 & 19 & 46 & 30 & 54 \\
\hline $\mathrm{La}$ & 11 & 6 & 7 & 6 & 7 & 7 & 7 & 6 & 6 & 6 & 6 & 6 & 6 & 7 & 7 & 8 & 5 \\
\hline $\mathrm{Ce}$ & $<1$ & 6 & $<1$ & 7 & 5 & 2 & 5 & 6 & $<1$ & 2 & $<1$ & 4 & 4 & $<1$ & 2 & 5 & 2 \\
\hline $\mathrm{Nd}$ & $<1$ & 3 & 2 & 3 & 3 & 2 & 2 & 4 & 2 & 1 & $<1$ & 3 & 3 & I & 2 & 3 & 3 \\
\hline $\mathrm{Pb}$ & 3 & 6 & 3 & 3 & 2 & 4 & $<1$ & $<1$ & 2 & 1 & 2 & 5 & 4 & $<1$ & $<1$ & 2 & 2 \\
\hline Th & $<1$ & 2 & $<1$ & $<1$ & $<1$ & $<1$ & 7 & 9 & 2 & $<1$ & $<1$ & 2 & $<1$ & $<1$ & $<1$ & $<1$ & $<1$ \\
\hline $\mathrm{Zr} / \mathrm{Nb}$ & 12.0 & $>31.0$ & $>36.0$ & 14.0 & $>31.0$ & $>30.0$ & $>27.0$ & $>30.0$ & $>33.0$ & $>30.0$ & $>35.0$ & $>28.0$ & $>30.0$ & $>36.0$ & $>39.0$ & $>34.0$ & $>36.0$ \\
\hline $\mathrm{Ti} / \mathrm{Zr}$ & 37.0 & 66.0 & 57.0 & 59.0 & 65.0 & 71.0 & 66.0 & 67.0 & 59.0 & 60.0 & 52.0 & 64.0 & 60.0 & 50.0 & 54.0 & 62.0 & 61.0 \\
\hline $\mathrm{Y} / \mathrm{Zr}$ & $<0.04$ & 0.26 & 0.17 & 0.25 & 0.10 & 0.07 & 0.19 & 0.07 & 0.24 & 0.20 & 0.23 & 0.21 & 0.30 & 0.33 & 0.08 & 0.15 & 0.33 \\
\hline $\mathrm{Ce} / \mathrm{Zr}$ & $<0.04$ & 0.19 & $<0.02$ & 0.25 & 0.16 & 0.07 & 0.19 & 0.20 & $<0.03$ & 0.07 & $<0.03$ & 0.14 & 0.13 & $<0.03$ & 0.05 & 0.15 & 0.06 \\
\hline $\mathrm{Ba} / \mathrm{Zr}$ & 2.46 & 1.32 & 0.61 & 1.18 & 0.42 & 0.50 & 2.00 & 0.20 & 1.06 & 1.63 & 0.83 & 1.82 & 1.57 & 0.53 & 1.18 & 0.88 & 1.50 \\
\hline$(\mathrm{Ce} / \mathrm{Y})_{\mathrm{N}}$ & 2.46 & 1.84 & - & 2.46 & 4.09 & 2.46 & 2.46 & 7.37 & - & 0.82 & - & 1.64 & 1.09 & - & 1.64 & - & 0.41 \\
\hline $\mathrm{Fe} / \mathrm{Mg}$ & 0.85 & 2.12 & 1.85 & 1.77 & 1.18 & 1.22 & 1.72 & 1.43 & 2.10 & 2.15 & 2.34 & 1.28 & 1.88 & 1.94 & 1.50 & 1.35 & 1.42 \\
\hline $\mathrm{K} / \mathrm{Rb}$ & 648.0 & 747.0 & 1141.0 & 452.0 & 785.0 & 1453.0 & 1155.0 & 1033.0 & 154.0 & 163.0 & 85.0 & 391.0 & 387.0 & 531.0 & 817.0 & 1743.0 & 347.0 \\
\hline $\mathrm{Ba} / \mathrm{Sr}$ & 1.07 & 0.34 & 0.18 & 0.36 & 0.12 & 0.15 & 0.78 & 0.06 & 0.30 & 0.46 & 0.28 & 0.51 & 0.44 & 0.22 & 0.37 & 0.28 & 0.45 \\
\hline Q & 0.0 & 1.3 & 0.8 & 12.3 & 0.0 & 0.0 & 0.0 & 0.5 & 7.3 & 11.8 & 12.6 & 11.3 & 6.9 & 14.2 & 0.9 & 0.0 & 0.0 \\
\hline Or & 9.9 & 3.7 & 5.7 & 2.6 & 7.3 & 5.2 & 9.2 & 6.6 & 5.0 & 7.0 & 6.9 & 3.6 & 6.6 & 4.9 & 4.7 & 6.3 & 8.2 \\
\hline $\mathrm{Ab}$ & 23.2 & 23.4 & 22.5 & 17.1 & 22.0 & 22.5 & 27.0 & 22.5 & 23.4 & 19.8 & 21.1 & 18.6 & 21.9 & 19.5 & 23.8 & 26.0 & 24.4 \\
\hline An & 4.8 & 34.9 & 35.0 & 28.0 & 26.6 & 25.2 & 30.6 & 28.7 & 25.9 & 24.3 & 23.3 & 23.8 & 24.8 & 24.5 & 30.1 & 24.8 & 24.4 \\
\hline $\mathrm{Ne}$ & 0.0 & 0.0 & 0.0 & 0.0 & 0.0 & 0.0 & 0.0 & 0.0 & 0.0 & 0.0 & 0.0 & 0.0 & 0.0 & 0.0 & 0.0 & 0.0 & 0.0 \\
\hline Di & 3.6 & 16.8 & 17.2 & 16.9 & 15.6 & 14.9 & 8.0 & 15.0 & 20.6 & 18.7 & 18.4 & 15.9 & 22.9 & 19.1 & 15.0 & 12.1 & 21.1 \\
\hline $\mathrm{Hy}$ & 49.3 & 16.6 & 16.0 & 20.0 & 22.2 & 23.5 & 14.7 & 23.5 & 14.7 & 15.3 & 14.6 & 23.8 & 14.0 & 14.9 & 22.5 & 21.7 & 11.7 \\
\hline ol & 5.6 & 0.0 & 0.0 & 0.0 & 3.3 & 5.3 & 7.4 & 0.0 & 0.0 & 0.0 & 0.0 & 0.0 & 0.0 & 0.0 & 0.0 & 5.8 & 6.9 \\
\hline Mt & 2.1 & 1.6 & 1.5 & 1.7 & 1.6 & 1.8 & 1.7 & 1.6 & 1.6 & 1.6 & 1.6 & 1.5 & 1.5 & 1.5 & 1.6 & 1.8 & 1.6 \\
\hline II & 0.3 & 0.6 & 0.6 & 0.5 & 0.6 & 0.7 & 0.6 & 0.6 & 0.6 & 0.6 & 0.6 & 0.6 & 0.6 & 0.6 & 0.7 & 0.7 & 0.7 \\
\hline Ap & 0.0 & 0.1 & 0.1 & 0.0 & 0.0 & 0.0 & 0.0 & 0.0 & 0.1 & 0.1 & 0.1 & 0.1 & 0.1 & 0.1 & 0.0 & 0.0 & 0.1 \\
\hline
\end{tabular}


Table 8. (Continued).

\begin{tabular}{|c|c|c|c|c|c|c|c|c|c|c|c|c|c|c|c|c|c|}
\hline $\begin{array}{l}37-2 \\
62-64\end{array}$ & $\begin{array}{l}38-1, \\
51-53\end{array}$ & $\begin{array}{l}39-1 \\
37-39\end{array}$ & $\begin{array}{l}39-2, \\
94-96\end{array}$ & $\begin{array}{l}40-2, \\
90-92\end{array}$ & $\begin{array}{l}41-1 \\
22-24\end{array}$ & $\begin{array}{l}42-1 \\
61-63\end{array}$ & $\begin{array}{l}42-1 \\
86-88\end{array}$ & $\begin{array}{c}43-1 \\
118-120\end{array}$ & $\begin{array}{l}44-1 \\
53-55\end{array}$ & $\begin{array}{l}45-1 \text {, } \\
8-10\end{array}$ & $\begin{array}{l}45-1 \\
24-26\end{array}$ & $\begin{array}{l}46-1 \\
75-77\end{array}$ & $\begin{array}{l}46-1 \\
83-85\end{array}$ & $\begin{array}{l}47-1 \\
67-69\end{array}$ & $\begin{array}{l}47-2 \\
90-92\end{array}$ & $\begin{array}{l}48-1 \\
79-81\end{array}$ & $\begin{array}{c}49-1 \\
136-138\end{array}$ \\
\hline 54.2 & 54.9 & 54.8 & 52.5 & 52.8 & 53.2 & 52.7 & 54.8 & 54.5 & 54.7 & 54.1 & 52.8 & 52.8 & 52.6 & 52.0 & 51.8 & 52.2 & 50.6 \\
\hline 0.34 & 0.30 & 0.28 & 0.36 & 0.35 & 1.13 & 0.58 & 0.49 & 0.51 & 0.49 & 0.49 & 0.56 & 1.13 & 1.16 & 1.11 & 1.09 & 1.07 & 1.04 \\
\hline 15.0 & 14.7 & 14.4 & 15.7 & 14.9 & 15.5 & 15.5 & 13.6 & 14.2 & 14.3 & 12.9 & 15.3 & 13.6 & 14.0 & 14.3 & 14.2 & 13.8 & 13.9 \\
\hline 9.02 & 8.92 & 9.34 & 9.43 & 10.24 & 9.66 & 11.11 & 10.37 & 10.61 & 10.19 & 10.29 & 10.69 & 13.82 & 13.74 & 13.05 & 13.53 & 13.88 & 13.73 \\
\hline 0.10 & 0.12 & 0.15 & 0.15 & 0.09 & 0.06 & 0.08 & 0.16 & 0.16 & 0.15 & 0.15 & 0.08 & 0.10 & 0.09 & 0.10 & 0.10 & 0.16 & 0.09 \\
\hline 7.34 & 6.36 & 6.42 & 9.16 & 8.97 & 3.73 & 6.76 & 6.12 & 6.25 & 5.78 & 5.64 & 6.71 & 6.17 & 6.33 & 6.85 & 7.32 & 5.51 & 7.96 \\
\hline 9.89 & 10.68 & 9.40 & 8.39 & 7.98 & 6.12 & 8.51 & 8.35 & 7.88 & 7.97 & 8.20 & 9.09 & 5.88 & 6.06 & 7.42 & 6.78 & 6.65 & 6.51 \\
\hline 2.79 & 2.66 & 2.14 & 2.63 & 2.47 & 5.70 & 2.94 & 2.54 & 2.48 & 2.45 & 2.54 & 2.95 & 3.41 & 3.46 & 3.55 & 3.20 & 2.59 & 3.63 \\
\hline 1.27 & 1.14 & 0.54 & 0.86 & 1.03 & 1.52 & 0.83 & 0.57 & 0.57 & 0.53 & 0.51 & 0.97 & 0.75 & 0.69 & 0.48 & 0.49 & 0.72 & 1.36 \\
\hline 0.05 & 0.04 & 0.01 & 0.01 & 0.01 & 0.20 & 0.05 & 0.02 & 0.02 & 0.02 & 0.02 & 0.07 & 0.06 & 0.09 & 0.14 & 0.10 & 0.02 & 0.11 \\
\hline 100.02 & 99.81 & 97.49 & 99.20 & 98.86 & 96.83 & 99.03 & 96.98 & 97.22 & 96.66 & 94.81 & 99.16 & 97.74 & 98.26 & 98.99 & 98.66 & 96.58 & 98.95 \\
\hline 65 & 75 & 71 & 99 & 97 & 11 & 65 & 75 & 82 & 76 & 77 & 71 & 23 & 28 & 21 & 35 & 24 & 19 \\
\hline 185 & 219 & 172 & 217 & 290 & 11 & 176 & 170 & 157 & 164 & 167 & 165 & 11 & 10 & 10 & 16 & 14 & 13 \\
\hline 53 & 53 & 60 & 51 & 83 & 88 & 82 & 59 & 65 & 60 & 60 & 68 & 109 & 111 & 92 & 102 & 92 & 69 \\
\hline 18 & 16 & 12 & 14 & 16 & 25 & 18 & 13 & 12 & 13 & 14 & 17 & 18 & 20 & 26 & 24 & 15 & 21 \\
\hline 34 & 19 & 7 & 3 & 12 & 25 & 15 & 6 & 7 & 8 & 8 & 19 & 13 & 12 & 8 & 7 & 9 & 20 \\
\hline 115 & 109 & 86 & 102 & 104 & 169 & 134 & 94 & 94 & 101 & 100 & 139 & 144 & 149 & 151 & 138 & 111 & 138 \\
\hline 9 & 8 & 6 & $<1$ & 2 & 31 & 20 & 11 & 10 & 11 & 11 & 25 & 20 & 26 & 25 & 34 & 17 & 19 \\
\hline 32 & 31 & 29 & 35 & 38 & 101 & 58 & 44 & 51 & 44 & 51 & 47 & 65 & 68 & 69 & 64 & 59 & 47 \\
\hline$<1$ & $<1$ & $<1$ & $<1$ & $<1$ & 1 & $<1$ & $<1$ & $<1$ & $<1$ & $<1$ & $<1$ & $<1$ & $<1$ & $<1$ & $<1$ & $<1$ & $<1$ \\
\hline 44 & 39 & 25 & 20 & 18 & 79 & 19 & 42 & 49 & 29 & 41 & 80 & 63 & 43 & 44 & 37 & 77 & 83 \\
\hline 6 & 6 & 6 & 4 & 7 & 9 & 7 & 5 & 6 & 6 & 5 & 9 & 10 & 9 & 8 & 11 & 7 & 8 \\
\hline 2 & 4 & $<1$ & $<1$ & 5 & 15 & 9 & 3 & 3 & 8 & $<1$ & 9 & 10 & 12 & 7 & 7 & 5 & 8 \\
\hline 3 & 4 & $<1$ & $<1$ & 2 & 11 & 6 & 2 & 4 & 4 & 2 & 6 & 7 & 8 & 5 & 6 & 3 & 7 \\
\hline 1 & 2 & 3 & 11 & $<1$ & 6 & 3 & 6 & 1 & 4 & 4 & $<1$ & 1 & $<1$ & 4 & 3 & 2 & 3 \\
\hline$<1$ & $<1$ & $<1$ & $<1$ & $<i$ & $<1$ & $<1$ & $<1$ & $i$ & $<1$ & 2 & $<1$ & 2 & 2 & 6 & $<1$ & $<1$ & $<1$ \\
\hline$>32.0$ & $>31.0$ & $>29.0$ & $>35.0$ & $>38.0$ & 101.0 & $>58.0$ & $>44.0$ & $>51.0$ & $>44.0$ & $>51.0$ & $>47.0$ & $>65.0$ & $>68.0$ & $>69.0$ & $>64.0$ & $>59.0$ & $>47.0$ \\
\hline 64.0 & 58.0 & 59.0 & 61.0 & 55.0 & 67.0 & 60.0 & 67.0 & 61.0 & 66.0 & 57.0 & 72.0 & 104.0 & 102.0 & 96.0 & 102.0 & 109.0 & 133.0 \\
\hline 0.28 & 0.26 & 0.21 & $<0.03$ & 0.05 & 0.31 & 0.34 & 0.25 & 0.20 & 0.25 & 0.22 & 0.53 & 0.31 & 0.38 & 0.36 & 0.53 & 0.29 & 0.40 \\
\hline 0.06 & 0.13 & $<0.03$ & $<0.03$ & 0.13 & 0.15 & 0.16 & 0.07 & 0.06 & 0.18 & $<0.02$ & 0.19 & 0.15 & 0.18 & 0.10 & 0.11 & 0.08 & 0.17 \\
\hline 1.37 & 1.26 & 0.86 & 0.57 & 0.47 & 0.78 & 0.33 & 0.95 & 0.96 & 0.66 & 0.80 & 1.70 & 0.97 & 0.63 & 0.64 & 0.58 & 1.31 & 1.77 \\
\hline 0.55 & 1.23 & - & 2.46 & 6.14 & 1.19 & 1.11 & 0.67 & 0.74 & 1.79 & - & 0.88 & 1.23 & 1.13 & 0.69 & 0.51 & 0.72 & 1.03 \\
\hline 1.43 & 1.63 & 1.69 & 1.19 & 1.32 & 3.00 & 1.91 & 1.97 & 1.97 & 2.04 & 2.12 & 1.85 & 2.60 & 2.52 & 2.21 & 2.14 & 2.92 & 2.00 \\
\hline 310.0 & 498.0 & 644.0 & 2382.0 & 713.0 & 505.0 & 462.0 & 784.0 & 681.0 & 550.0 & 533.0 & 425.0 & 479.0 & 479.0 & 501.0 & 575.0 & 665.0 & 564.0 \\
\hline 0.38 & 0.36 & 0.29 & 0.20 & 0.17 & 0.47 & 0.14 & 0.45 & 0.52 & 0.29 & 0,41 & 0.58 & 0.44 & 0.29 & 0.29 & 0.27 & 0.69 & 0.60 \\
\hline 1.0 & 3.4 & 9.2 & 0.0 & 0.7 & 0.0 & 1.0 & 8.7 & 8.5 & 9.9 & 9.7 & 0.5 & 2.7 & 1.9 & 0.0 & 0.7 & 6.2 & 0.0 \\
\hline 7.5 & 6.7 & 3.3 & 5.1 & 6.2 & 9.3 & 5.0 & 3.5 & 3.5 & 3.2 & 3.2 & 5.8 & 4.5 & 4.2 & 2.9 & 2.9 & 4.4 & 8.1 \\
\hline 23.6 & 22.5 & 18.6 & 22.4 & 21.1 & 45.7 & 25.1 & 22.2 & 21.6 & 21.4 & 22.7 & 25.2 & 29.5 & 29.8 & 30.3 & 27.4 & 22.7 & 31.0 \\
\hline 24.6 & 24.9 & 28.7 & 28.9 & 26.9 & 12.5 & 26.9 & 24.7 & 26.7 & 27.5 & 23.5 & 25.8 & 20.1 & 21.0 & 21.9 & 23.3 & 24.7 & 17.9 \\
\hline 0.0 & 0.0 & 0.0 & 0.0 & 0.0 & 2.2 & 0.0 & 0.0 & 0.0 & 0.0 & 0.0 & 0.0 & 0.0 & 0.0 & 0.0 & 0.0 & 0.0 & 0.0 \\
\hline 19.7 & 22.9 & 15.6 & 10.6 & 10.7 & 14.6 & 12.7 & 14.7 & 11.1 & 11.0 & 15.9 & 15.8 & 7.8 & 7.5 & 11.9 & 8.4 & 7.8 & 11.5 \\
\hline 20.5 & 16.5 & 21.5 & 28.1 & 31.0 & 0.0 & 25.1 & 22.4 & 24.8 & 23.2 & 21.1 & 22.9 & 29.3 & 29.5 & 25.7 & 31.3 & 28.3 & 8.6 \\
\hline 0.0 & 0.0 & 0.0 & 1.6 & 0.0 & 10.4 & 0.0 & 0.0 & 0.0 & 0.0 & 0.0 & 0.0 & 0.0 & 0.0 & 1.4 & 0.0 & 0.0 & 16.8 \\
\hline 1.6 & 1.6 & 1.7 & 1.7 & 1.8 & 1.7 & 2.0 & 1.9 & 1.9 & 1.8 & 1.9 & 1.9 & 2.5 & 2.4 & 2.3 & 2.4 & 2.5 & 2.4 \\
\hline 0.6 & 0.6 & 0.6 & 0.7 & 0.7 & 2.2 & 1.1 & 1.0 & 1.0 & 1.0 & 1.0 & 1.1 & 2.2 & 2.2 & 2.2 & 2.1 & 2.1 & 2.0 \\
\hline 0.1 & 0.1 & 0.0 & 0.0 & 0.0 & 0.5 & 0.1 & 0.1 & 0.0 & 0.1 & 0.1 & 0.2 & 0.1 & 0.2 & 0.3 & 0.2 & 0.1 & 0.3 \\
\hline
\end{tabular}


Table 9. Representative major element analyses of boninites selected from the literature.

\begin{tabular}{lrrrrr}
\hline & \multicolumn{1}{c}{1} & \multicolumn{1}{c}{2} & \multicolumn{1}{c}{3} & \multicolumn{1}{c}{4} & \multicolumn{1}{c}{5} \\
\hline $\mathrm{SiO}_{2}$ & 53.76 & 56.88 & 56.46 & 55.56 & 54.09 \\
$\mathrm{TiO}_{2}$ & 0.24 & 0.28 & 0.29 & 0.21 & 0.30 \\
$\mathrm{Al}_{2} \mathrm{O}_{3}$ & 12.53 & 13.76 & 14.65 & 10.25 & 8.39 \\
$\mathrm{Fe}_{2} \mathrm{O}_{3}$ & 0.63 & 1.59 & 5.07 & 2.85 & 3.65 \\
$\mathrm{FeO}$ & 6.48 & 6.41 & 3.06 & 5.86 & 6.54 \\
$\mathrm{MnO}$ & 0.16 & 0.22 & 0.13 & 0.18 & 0.15 \\
$\mathrm{MgO}$ & 11.93 & 5.44 & 6.92 & 13.57 & 13.03 \\
$\mathrm{CaO}$ & 6.44 & 7.99 & 8.19 & 5.91 & 5.46 \\
$\mathrm{Na}_{2} \mathrm{O}$ & 1.90 & 2.17 & 2.69 & 1.51 & 0.75 \\
$\mathrm{~K}_{2} \mathrm{O}$ & 0.68 & 0.49 & 1.28 & 0.69 & 0.41 \\
$\mathrm{P}_{2} \mathrm{O}_{5}$ & 0.06 & 0.07 & 0.05 & 0.03 & 0.07 \\
$\mathrm{H}_{2} \mathrm{O}+$ & 5.13 & 4.40 & 2.42 & 3.65 & 7.4 \\
$\mathrm{Total}$ & 99.94 & 99.70 & 101.21 & 100.29 & 100.20 \\
\hline
\end{tabular}

Notes:

1 = boninite, Bonin Islands, Kuroda et al. (1978).

2 = bronzite andesite, Bonin Islands, Kuroda et al. (1978).

$3=1403-24$ contact rock, Mariana Trench, Dietrich et al. (1978).

$4=1403-34$ enstalite porphyritic boninite, Mariana Trench, Dietrich et al. (1978).

$5=\mathrm{LB} 105$ clinoenstatite-bearing, high-Mg andesite, Dabi Volcanics, Cape Vogel, Papua, Dallwitz et al. (1966).

Table 10. Major and trace element analyses of igneous rocks from Hole 459B.

\begin{tabular}{|c|c|c|c|c|c|c|c|c|c|c|c|c|c|c|c|c|c|}
\hline $\begin{array}{c}\text { Sample } \\
\text { (interval } \\
\text { in } \mathrm{cm} \text { ) }\end{array}$ & $\begin{array}{l}60-2 \\
80-82\end{array}$ & $\begin{array}{c}\text { 61-1, } \\
115-117\end{array}$ & $\begin{array}{c}61-2 \\
47-49\end{array}$ & $\begin{array}{l}\text { 63-1, } \\
53-55\end{array}$ & $\begin{array}{l}64-1 \\
41-43\end{array}$ & $\begin{array}{l}65-1 \\
59-61\end{array}$ & $\begin{array}{l}66-1 \\
73-75\end{array}$ & $\begin{array}{c}66-2 \\
147-149\end{array}$ & $\begin{array}{c}67-1 \\
118-120\end{array}$ & $\begin{array}{l}68-1 \\
51-53\end{array}$ & $\begin{array}{c}69-1 \\
144-146\end{array}$ & $\begin{array}{l}69-3, \\
83-85\end{array}$ & $\begin{array}{l}70-1 \\
49-51\end{array}$ & $\begin{array}{l}71-2 \\
38-40\end{array}$ & $\begin{array}{c}71-2 \\
105-107\end{array}$ & $\begin{array}{l}73-1 \text {, } \\
38-40\end{array}$ & $\begin{array}{c}73-3 \\
118-120\end{array}$ \\
\hline $\mathrm{SiO}_{2}$ & 54.6 & 53.8 & 54.4 & 51.1 & 51.3 & 52.6 & 56.2 & 56.5 & 57.4 & 58.6 & 56.8 & 56.0 & 55.4 & 57.2 & 57.2 & 53.1 & 52.9 \\
\hline $\mathrm{TiO}_{2}^{2}$ & 0.74 & 0.66 & 0.67 & 0.83 & 0.82 & 1.21 & 0.99 & 0.98 & 0.93 & 0.72 & 0.76 & 0.94 & 0.88 & 1.14 & 1.12 & 1.14 & 1.11 \\
\hline $\mathrm{Al}_{2} \overline{\mathrm{O}}_{3}$ & 14.7 & 14.9 & 14.2 & 14.8 & 13.8 & 13.9 & 13.4 & 13.2 & 12.8 & 12.2 & 14.4 & 14.3 & 14.2 & 12.8 & 13.4 & 14.0 & 15.3 \\
\hline $\mathrm{tFe}_{2} \mathrm{O}_{3}$ & 10.13 & 9.90 & 9.83 & 10.02 & 11.31 & 13.63 & 11.85 & 11.98 & 11.84 & 11.41 & 10.23 & 11.18 & 10.86 & 12.29 & 11.93 & 12.03 & 11.38 \\
\hline $\mathrm{MnO}$ & 0.14 & 0.14 & 0.14 & 0.14 & 0.14 & 0.16 & 0.15 & 0.15 & 0.14 & 0.12 & 0.11 & 0.11 & 0.11 & 0.11 & 0.11 & 0.13 & 0.10 \\
\hline $\mathrm{MgO}$ & 5.55 & 6.40 & 5,40 & 9.37 & 9.90 & 6.07 & 5.53 & 4.80 & 4.95 & 5.17 & 5.87 & 5.17 & 5.62 & 5.07 & 5.37 & 5.77 & 4.54 \\
\hline $\mathrm{CaO}$ & 10.27 & 10.65 & 11.53 & 8.77 & 8.17 & 6.06 & 7.35 & 7.38 & 7.02 & 6.82 & 8.43 & 7.93 & 8.57 & 6.71 & 7.02 & 8.17 & 7.67 \\
\hline $\mathrm{Na}_{2} \mathrm{O}$ & 2.98 & 2.96 & 2.67 & 3.30 & 3.32 & 3.73 & 3.27 & 3.12 & 3.14 & 2.89 & 3.40 & 3.83 & 3.58 & 3.64 & 3.86 & 4.02 & 4.57 \\
\hline $\mathrm{K}_{2} \mathrm{O}$ & 0.47 & 0.44 & 0.54 & 0.68 & 0.57 & 0.89 & 0.63 & 0.86 & 1.45 & 1.89 & 0.69 & 1.00 & 0.82 & 1.03 & 0.84 & 0.98 & 1.22 \\
\hline $\mathrm{P}_{2} \mathrm{O}_{5}$ & 0.07 & 0.07 & 0.07 & 0.08 & 0.09 & 0.06 & 0.08 & 0.08 & 0.08 & 0.07 & 0.08 & 0.10 & 0.09 & 0.10 & 0.11 & 0.11 & 0.14 \\
\hline Total & 99.69 & 99.97 & 99.48 & 99.12 & 99.38 & 98.35 & 99.41 & 99.03 & 99.70 & 99.90 & 100.81 & 100.59 & 100.13 & 100.07 & 100.89 & 99.44 & 98.88 \\
\hline $\mathrm{Ni}$ & 43 & 57 & 54 & 68 & 52 & 24 & 24 & 21 & 24 & 30 & 28 & 22 & 30 & 11 & 14 & 20 & 11 \\
\hline $\mathrm{Cr}$ & 131 & 159 & 141 & 67 & 56 & 13 & 17 & 13 & 16 & 22 & 23 & 20 & 55 & 14 & 13 & 22 & 14 \\
\hline $\mathrm{Zn}$ & 60 & 65 & 60 & 90 & 87 & 115 & 72 & 70 & 107 & 85 & 66 & 74 & 65 & 82 & 89 & 83 & 80 \\
\hline $\mathrm{Ga}_{2}$ & 16 & 17 & 16 & 18 & 22 & 25 & 22 & 19 & 18 & 17 & 20 & 21 & 21 & 21 & 22 & 22 & 23 \\
\hline $\mathbf{R b}$ & 27 & 24 & 15 & 6 & 5 & 13 & 28 & 46 & 22 & 26 & 12 & 28 & 11 & 16 & 11 & 13 & 19 \\
\hline $\mathrm{Sr}$ & 121 & 120 & 116 & 127 & 123 & 125 & 109 & 107 & 109 & 115 & 144 & 131 & 139 & 121 & 123 & 134 & 159 \\
\hline$Y$ & 15 & 15 & 15 & 20 & 37 & 27 & 24 & 22 & 22 & 19 & 19 & 24 & 27 & 34 & 30 & 27 & 38 \\
\hline $\mathrm{Zr}$ & 38 & 38 & 36 & 53 & 52 & 68 & 56 & 54 & 50 & 46 & 51 & 61 & 57 & 63 & 73 & 66 & 75 \\
\hline $\mathrm{Nb}$ & $<1$ & $<1$ & $<1$ & $<1$ & $<1$ & $<1$ & $<1$ & 1 & $<1$ & $<1$ & $<1$ & $<1$ & 1 & $<1$ & 1 & $<1$ & $<1$ \\
\hline $\mathrm{Ba}$ & 38 & 24 & 20 & 19 & 86 & 37 & 33 & $3 i$ & 37 & 38 & 28 & 40 & 75 & 48 & 51 & 46 & 37 \\
\hline $\mathrm{La}$ & 7 & 7 & 8 & 5 & 5 & 6 & 6 & 7 & 12 & 10 & 9 & 10 & 9 & 11 & 8 & 9 & 11 \\
\hline $\mathrm{Ce}$ & $<1$ & 3 & 3 & 5 & 8 & 11 & 4 & 9 & 4 & 5 & 7 & 5 & 9 & 10 & 7 & 9 & 17 \\
\hline $\mathrm{Nd}$ & 2 & 2 & 3 & 4 & 7 & 10 & 4 & 6 & 5 & 5 & 6 & 5 & 5 & 7 & 8 & 8 & 11 \\
\hline $\mathrm{Pb}$ & $<1$ & 1 & 2 & 4 & 2 & 2 & 3 & $<1$ & 2 & 5 & 4 & 2 & 5 & 2 & 4 & 4 & 2 \\
\hline Th & $<1$ & $<1$ & 1 & $<1$ & $<1$ & 3 & $<1$ & 2 & 2 & 1 & 1 & 1 & 4 & $<1$ & 2 & 1 & 3 \\
\hline $\mathrm{Zr} / \mathrm{Nb}$ & $>38.0$ & $>38.0$ & $>36.0$ & $>53.0$ & $>52.0$ & $>68.0$ & $>56.0$ & 54.0 & $>50.0$ & $>46.0$ & $>51.0$ & $>61.0$ & 57.0 & $>63.0$ & 73.0 & $>66.0$ & $>75.0$ \\
\hline $\mathrm{Ti} / \mathrm{Zr}$ & 117.0 & 104.0 & 111.0 & 94.0 & 95.0 & 107.0 & 106.0 & 109.0 & 112.00 & 94.0 & 89.0 & 93.0 & 92.0 & 108.0 & 92.0 & 104.0 & 89.0 \\
\hline $\mathrm{Y} / \mathrm{Zr}$ & 0.39 & 0.39 & 0.42 & 0.38 & 0.71 & 0.40 & 0.43 & 0.41 & 0.44 & 0.41 & 0.37 & 0.39 & 0.47 & 0.54 & 0.41 & 0.41 & 0.51 \\
\hline $\mathrm{Ce} / \mathrm{Zr}$ & $<0.03$ & 0.08 & 0.08 & 0.09 & 0.15 & 0.16 & 0.07 & 0.17 & 0.08 & 0.11 & 0.14 & 0.08 & 0.16 & 0.16 & 0.10 & 0.14 & 0.23 \\
\hline $\mathrm{Ba} / \mathrm{Zr}$ & 1.00 & 0.63 & 0.56 & 0.36 & 1.65 & 1.13 & 0.59 & 0.57 & 0.74 & 0.83 & 0.55 & 0.66 & 1.32 & 0.76 & 0.70 & 0.70 & 0.49 \\
\hline$(\mathrm{Ce} / \mathrm{Y})_{\mathrm{N}}$ & - & 0.49 & 0.49 & 0.61 & 0.53 & 1.00 & 0.41 & 1.00 & 0.45 & 0.65 & 0.90 & 0.51 & 0.82 & 0.72 & 0.57 & 0.82 & 1.10 \\
\hline $\mathrm{Fe} / \mathrm{Mg}$ & 2.12 & 1.79 & 2.11 & 1.24 & 1.32 & 2.60 & 2.49 & 2.89 & 2.77 & 2.56 & 2.02 & 2.51 & 2.24 & 2.81 & 2.58 & 2.42 & 2.91 \\
\hline $\mathrm{K} / \mathrm{Rb}$ & 144.0 & 153.0 & 301.0 & 938.0 & 955.0 & 566.0 & 186.0 & 156.0 & 547.0 & 603.0 & 477.0 & 295.0 & 619.0 & 534.0 & 633.0 & 623,0 & 533.0 \\
\hline $\mathrm{Ba} / \mathrm{Sr}$ & 0.31 & 0.20 & 0.17 & 0.15 & 0.70 & 0.62 & 0.30 & 0.29 & 0.34 & 0.33 & 0.19 & 0.31 & 0.54 & 0.40 & 0.41 & 0.34 & 0.23 \\
\hline Q & 5.0 & 2.7 & 5.4 & 0.0 & 0.0 & 0.5 & 7.8 & 9.3 & 8.5 & 9.9 & 6.1 & 3.4 & 3.4 & 7.2 & 5.9 & 0.0 & 0.0 \\
\hline Or & 2.8 & 2.6 & 3.2 & 4.0 & 3.4 & 5.3 & 3.7 & 5.1 & 8.6 & 11.2 & 4.0 & 5.9 & 4.8 & 6.1 & 4.9 & 5.8 & 7.3 \\
\hline$A b$ & 25.3 & 25.1 & 22.7 & 28.2 & 28,3 & 32.1 & 27.8 & 26.7 & 26.6 & 24.5 & 28.5 & 32.2 & 30.3 & 30.8 & 32.4 & 34.2 & 39.1 \\
\hline An & 25.5 & 26.1 & 25.3 & 23.8 & 21.2 & 18.9 & 20.1 & 19.5 & 16.6 & 14.7 & 21.9 & 18.9 & 20.3 & 15.6 & 16.5 & 17.3 & 17.7 \\
\hline $\mathrm{Ne}$ & 0.0 & 0.0 & 0.0 & 0.0 & 0.0 & 0.0 & 0.0 & 0.0 & 0.0 & 0.0 & 0.0 & 0.0 & 0.0 & 0.0 & 0.0 & 0.0 & 0.0 \\
\hline $\mathrm{Di}$ & 20.8 & 21.6 & 26.2 & 15.9 & 15.5 & 9.4 & 13.4 & 14.1 & 14.9 & 15.5 & 15.7 & 16.3 & 17.9 & 14.2 & 14.4 & 18.9 & 16.5 \\
\hline $\mathrm{Hy}$ & 16.4 & 17.9 & 13.1 & 11.2 & 14.4 & 27.7 & 22.0 & 20.1 & 19.8 & 19.7 & 19.5 & 18.4 & 18.6 & 20.5 & 20.5 & 13.9 & 4.5 \\
\hline oi & 0.0 & 0.0 & 0.0 & 12.5 & 12.5 & 0.0 & 0.0 & 0.0 & 0.0 & 0.0 & 0.0 & 0.0 & 0.0 & 0.0 & 0.0 & 4.4 & 9.3 \\
\hline Mt & 1.8 & 1.7 & 1.7 & 1.8 & 2.0 & 2.4 & 2.1 & 2.1 & 2.1 & 2.0 & 1.8 & 1.9 & 1.9 & 2.1 & 2.1 & 2.1 & 2.0 \\
\hline II & 1.4 & 1.3 & 1.3 & 1.6 & 1.6 & 2.3 & 1.9 & 1.9 & 1.8 & 1.4 & 1.4 & 1.8 & 1.7 & 2.2 & 2.1 & 2.2 & 2.1 \\
\hline$A p$ & 0.2 & 0.2 & 0.2 & 0.2 & 0.2 & 0.2 & 0.2 & 0.2 & 0.2 & 0.2 & 0.2 & 0.2 & 0.2 & 0.2 & 0.2 & 0.3 & 0.3 \\
\hline
\end{tabular}




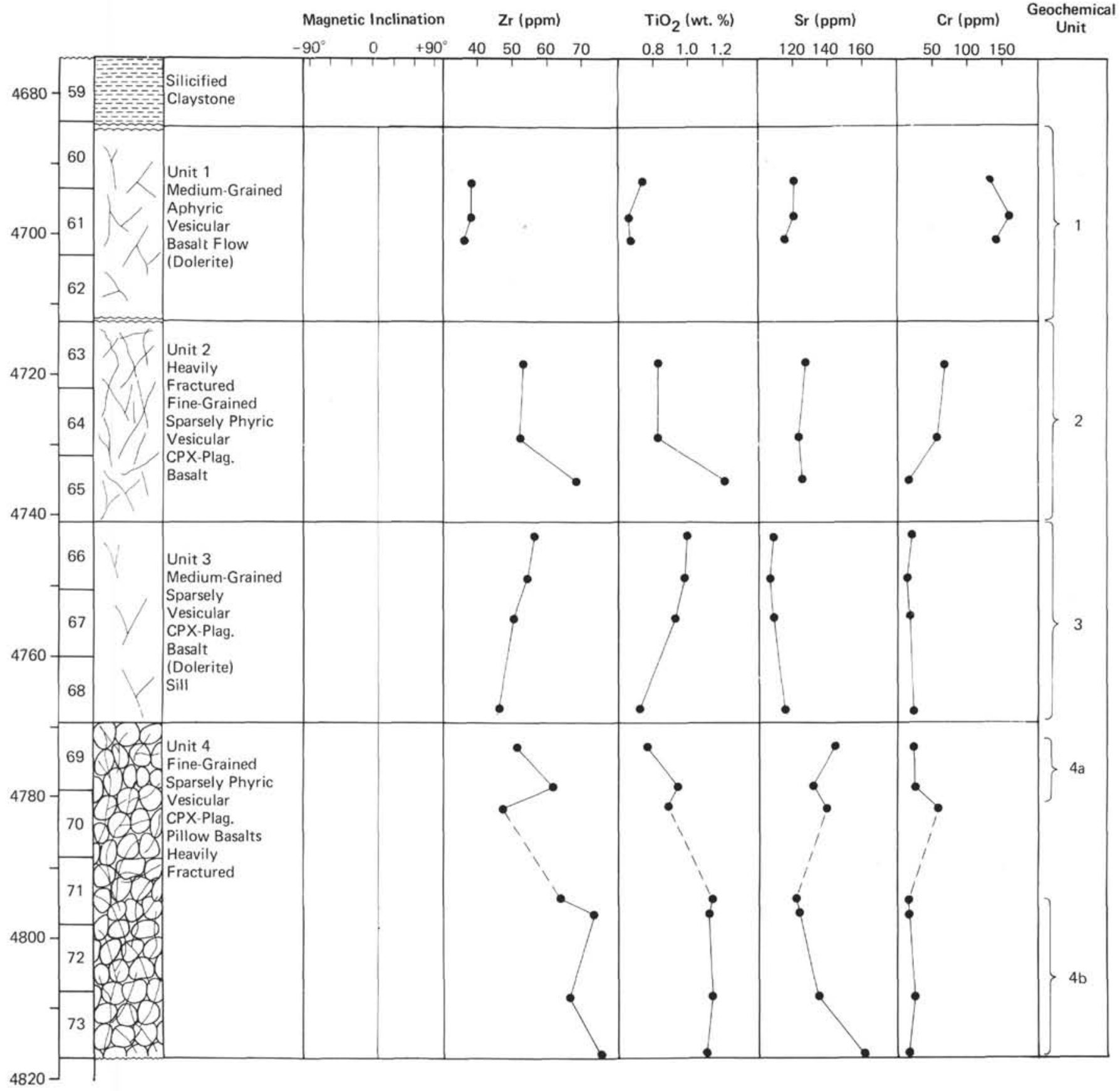

Figure 15. Geochemical and lithological stratigraphy of the basement sections of Hole 459B. 
Table 11. Representative major and trace element analyses of basement rocks recovered on DSDP Leg 60. Major element oxides in weight percent, trace elements in parts per million.

\begin{tabular}{|c|c|c|c|c|c|c|c|c|c|c|c|c|c|c|c|c|}
\hline \multirow{2}{*}{$\frac{\text { Location }}{\text { Lithological Unit }}$} & \multicolumn{6}{|c|}{ Mariana Trough } & \multicolumn{5}{|l|}{$\begin{array}{c}\text { Mariana } \\
\text { Ridge }\end{array}$} & \multirow[b]{2}{*}{$459 \mathrm{~B}-4 \mathrm{a}$} & \multicolumn{3}{|c|}{ Mariana Trench } & \\
\hline & $453-1$ & $453-2$ & 454A-pm1 & $454 \mathrm{~A}-\mathrm{pm} 3$ & $456-1$ & $456 \mathrm{~A}-3$ & 457 & $458-1$ & $458-4 a$ & $458-5$ & $459 \mathrm{~B}-1$ & & $460-1$ & $460-2$ & $461 \mathrm{~A}$ & \\
\hline $\mathrm{SiO}_{2}$ & 51.0 & 48.3 & 49.3 & 50.2 & 46.2 & 50.7 & 53.4 & 52.5 & 53.2 & 52.8 & 53.8 & 57.2 & 53.6 & 52.5 & 58.7 & $\mathrm{SiO}_{2}$ \\
\hline $\mathrm{TiO}_{2}$ & 1.00 & 0.83 & 0.86 & 1.12 & 1.26 & 1.18 & 0.89 & 0.34 & 1.13 & 1.13 & 0.66 & 1.14 & 1.34 & 0.87 & 1.01 & $\mathrm{TiO}_{2}$ \\
\hline $\mathrm{Al}_{2} \mathrm{O}_{3}$ & 15.7 & 15.2 & 14.4 & 14.5 & 12.3 & 16.6 & 15.6 & 18.0 & 15.5 & 13.6 & 14.9 & 12.8 & 16.6 & 15.2 & 13.2 & $\mathrm{Al}_{2} \mathrm{O}_{3}$ \\
\hline $\mathrm{Fe}_{2} \mathrm{O}_{3}$ & 1.35 & 1.39 & 1.12 & 1.18 & 1.22 & 1.17 & 1.35 & 1.11 & 1.15 & 1.64 & 1.18 & 1.46 & 1.26 & 1.51 & 1.67 & $\mathrm{Fe}_{2} \mathrm{O}_{3}$ \\
\hline $\mathrm{FeO}^{\mathrm{a}}$ & 9.01 & 9.25 & 7.47 & 7.86 & 8.10 & 7.82 & 8.97 & 7.38 & 7.66 & 10.96 & 7.85 & 9.74 & 8.38 & 10.09 & 11.15 & $\mathrm{FeO}^{\mathrm{a}}$ \\
\hline $\mathrm{MnO}$ & 0.15 & 0.17 & 0.12 & 0.16 & 0.29 & 0.16 & 0.14 & 0.11 & 0.06 & 0.10 & 0.14 & 0.11 & 0.07 & 0.13 & 0.13 & $\mathrm{MnO}$ \\
\hline $\mathrm{MgO}$ & 5.71 & 8.34 & 13.30 & 8.73 & 11.22 & 5.23 & 5.33 & 5.09 & 3.73 & 6.17 & 6.40 & 5.07 & 3.97 & 5.03 & 5.46 & $\mathrm{MgO}$ \\
\hline $\mathrm{CaO}$ & 9.86 & 13.47 & 10.97 & 10.42 & 12.55 & 11.23 & 6.47 & 11.17 & 61.2 & 5.88 & 10.65 & 6.71 & 5.45 & 8.24 & 3.00 & $\mathrm{CaO}$ \\
\hline $\mathrm{Na}_{2} \mathrm{O}$ & 2.93 & 1.69 & 2.36 & 2.64 & 2.40 & 3.27 & 2.73 & 2.77 & 5.70 & 3.41 & 2.96 & 3.64 & 5.51 & 3.06 & 3.50 & $\mathrm{Na}_{2} \mathrm{O}$ \\
\hline $\mathrm{K}_{2} \mathrm{O}$ & 0.56 & 0.21 & 0.18 & 0.44 & 0.06 & 0.62 & 1.13 & 0.63 & 1.52 & 0.75 & 0.44 & 1.03 & 1.68 & 0.91 & 0.22 & $\mathrm{~K}_{2} \mathrm{O}$ \\
\hline $\mathrm{P}_{2} \mathrm{O}_{5}$ & 0.31 & 0.03 & 0.09 & 0.09 & 0.11 & 0.11 & 0.11 & 0.03 & 0.20 & 0.06 & 0.07 & 0.10 & 0.23 & 0.05 & 0.08 & $\mathrm{P}_{2} \mathrm{O}_{5}$ \\
\hline $\mathrm{H}_{2} \mathrm{O}^{-}$ & n.d. & n.d. & n.d. & n.d. & n.d. & n.d. & n.d. & n.d. & n.d. & n.d. & n.d. & n.d. & n.d. & n.d. & n.d. & $\mathrm{H}_{2} \mathrm{O}^{+}$ \\
\hline Total & 97.66 & 98.96 & 100.14 & 97.38 & 95.66 & 98.05 & 96.02 & 99.15 & 95.98 & 96.52 & 99.10 & 98.99 & 98.07 & 97.62 & 98.19 & Total \\
\hline $\mathrm{Mg} /\left(\mathrm{Mg}+\mathrm{Fe}^{2+}\right)$ & 0.530 & 0.616 & 0.760 & 0.664 & 0.711 & 0.543 & 0.513 & 0.551 & 0.464 & 0.500 & 0.592 & 0.480 & 0.457 & 0.470 & 0.465 & $\mathrm{Mg} /\left(\mathrm{Mg}_{\mathrm{g}}+\mathrm{Fe}^{2+}\right)$ \\
\hline Total $\mathrm{Fe}$ as $\mathrm{FeO}$ & 10.23 & 10.50 & 8.48 & 8.93 & 9.20 & 8.88 & 10.19 & 8.38 & 8.69 & 12.43 & 8.91 & 11.06 & 9.51 & 11.45 & 12.65 & Total $\mathrm{Fe}$ as $\mathrm{FeO}$ \\
\hline Sc & 30.5 & 49.7 & 27.1 & 28.7 & 31.1 & 32.8 & 24.1 & 36.9 & 21.4 & 27.7 & 35.2 & 27,2 & 23,8 & 31.9 & 23.9 & Sc (INA) \\
\hline $\mathrm{Cr}$ & 16 & 21 & 532 & 390 & 276 & 106 & 29 & .214 & II & II & 159 & 14 & 5 & 51 & 15 & $\mathrm{Cr}$ (XRF) \\
\hline Co & 33.1 & 45.6 & 49.9 & 42.4 & 35.4 & 32.3 & 27.3 & 28.1 & 14.2 & 33.7 & 39.6 & 32.9 & 20.6 & 26.8 & 29.2 & Co (INA) \\
\hline $\mathrm{Ni}$ & 11 & 6 & 382 & 269 & 74 & 51 & 17 & 80 & 11 & 23 & 57 & 11 & 2 & 22 & 27 & $\mathrm{Ni}$ (XRF) \\
\hline $\mathrm{Zn}$ & 34 & 75 & 52 & 66 & 93 & 77 & 80 & 71 & 88 & 109 & 65 & 82 & 91 & 98 & 60 & $\mathrm{Zn}(\mathrm{XRF})$ \\
\hline $\mathrm{Ga}$ & 17 & 18 & 16 & 17 & 18 & 16 & 16 & 14 & 25 & 18 & 17 & 21 & 25 & 18 & 17 & $\mathrm{Ga}(\mathrm{XRF})$ \\
\hline $\mathrm{Rb}$ & 9 & 17 & 2 & 3 & $<1$ & 8 & 18 & 7 & 25 & 13 & 24 & 16 & 22 & 8 & 4 & $\mathrm{Rb}(\mathrm{XRF})$ \\
\hline $\mathrm{Sr}$ & 511 & 429 & 143 & 170 & 141 & 251 & 305 & 122 & 169 & 144 & 120 & 121 & 154 & 122 & 113 & Sr (XRF) \\
\hline $\mathrm{Y}$ & 25 & 21 & 18 & 23 & 24 & 26 & 19 & 8 & 31 & 20 & 15 & 34 & 52 & 17 & 16 & $\mathrm{Y}$ (XRF) \\
\hline $\mathrm{Zr}$ & 82 & 55 & 58 & $\pi$ & 82 & 84 & 81 & 31 & 101 & 65 & 38 & 63 & 83 & 48 & 69 & $\mathrm{Zr}(\mathrm{XRF})$ \\
\hline Cs & 0.08 & 0.03 & 0.01 & 0.02 & 0.02 & 0.16 & 0.41 & 0.09 & 0.44 & 0.18 & 1.14 & 0.25 & 0.38 & 0.06 & 0.25 & $\mathrm{Ca}$ (INA) \\
\hline Ba & 148 & 326 & 49 & 105 & 67 & 81 & 255 & 41 & 79 & 63 & 24 & 48 & 66 & 21 & 36 & $\mathrm{Ba}$ (XRF) \\
\hline $\mathrm{La}$ & 12.50 & 1.32 & 1.98 & 4.90 & 2.67 & 5.15 & 4.20 & 1.18 & 3.03 & 2.80 & 1.13 & 1.93 & 3.99 & 2.02 & 1.81 & La (INA) \\
\hline $\mathrm{Ce}$ & 24.3 & - & 6.6 & 9.2 & 8.1 & 13.1 & 9.7 & 2.3 & 7.5 & 6.1 & 2.9 & 6.0 & 8.4 & 1.3 & 4.0 & $\mathrm{Ce}$ (INA) \\
\hline Eu & 1.12 & 0.56 & 0.86 & 1.01 & 1.18 & 1.25 & 0.71 & 0.28 & 1.03 & 0.88 & 0.52 & 0.91 & 1.34 & 0.70 & 0.30 & Eu (INA) \\
\hline $\mathrm{Tb}$ & 0.62 & 0.34 & 0.48 & 0.64 & 0.62 & 0.67 & 0.47 & 0.20 & 0.57 & 0.50 & 0.34 & 0.55 & 0.84 & 0.38 & 0.32 & Tb (INA) \\
\hline $\mathrm{Hf}$ & 2.26 & 0.63 & 1.35 & 2.01 & 1.91 & 2.02 & 1.66 & 0.82 & 2.23 & 1.70 & 1.01 & 1.82 & 2.85 & 1.39 & 1.90 & Hf (INA) \\
\hline $\mathrm{Ta}$ & 0.11 & 0.02 & 0.11 & 0.16 & 0.16 & 0.16 & 0.08 & 0.06 & 0.12 & 0.09 & 0.05 & 0.07 & 0.13 & 0.09 & 0.08 & Ta (INA) \\
\hline Th & 2.38 & 0.14 & 0.24 & 0.32 & 0.20 & 0.63 & 0.73 & 0.15 & 0.23 & 0.16 & 0.10 & 0.18 & 0.32 & 0.21 & 0.25 & Th (INA) \\
\hline $\mathrm{U}$ & 0.63 & - & 0.12 & - & 0.05 & 0.18 & 0.25 & - & 0.13 & 0.10 & 0.03 & 0.17 & 0.13 & 0.26 & 0.15 & $\mathrm{U}$ (INA) \\
\hline
\end{tabular}

Notes:

Fe calculated as $\mathrm{Fe}_{2} \mathrm{O}_{3} / \mathrm{FeO}=0.15$

453-1 = Sample 453-52-1, 96-102 cm; 453-2 = Sample 453-57-1, 30-36 cm; 454A-pml = Sample 454A-5-4, 15-18 cm; 454A-pm3 = Sample 454A-16-1, 1111-114 cm. 456-1 Sample 456-16-2, 92-96 cm; 456A-3 = Sample 456A-13-1, 23-26 cm; 457 = Sample 457-4,CC; $458-1$ = Sample 458-28-1, 58-64 cm.

458-4a = Sample 458-41-1, 22-26 cm; 458-5 = Sample 458-46-1, 75-81 cm; 459B-1 = Sample 459B-61-1, 115-118 cm; 459B-4a = Sample 459B-71-2, 38-40 cm.

$460-1=$ Sample $460-9, C C, 11-13 \mathrm{~cm} ; 460-2=$ Sample $460-9$, CC, $74-76 \mathrm{~cm} ; 461 \mathrm{~A}-3-1,60-62 \mathrm{~cm}$. 


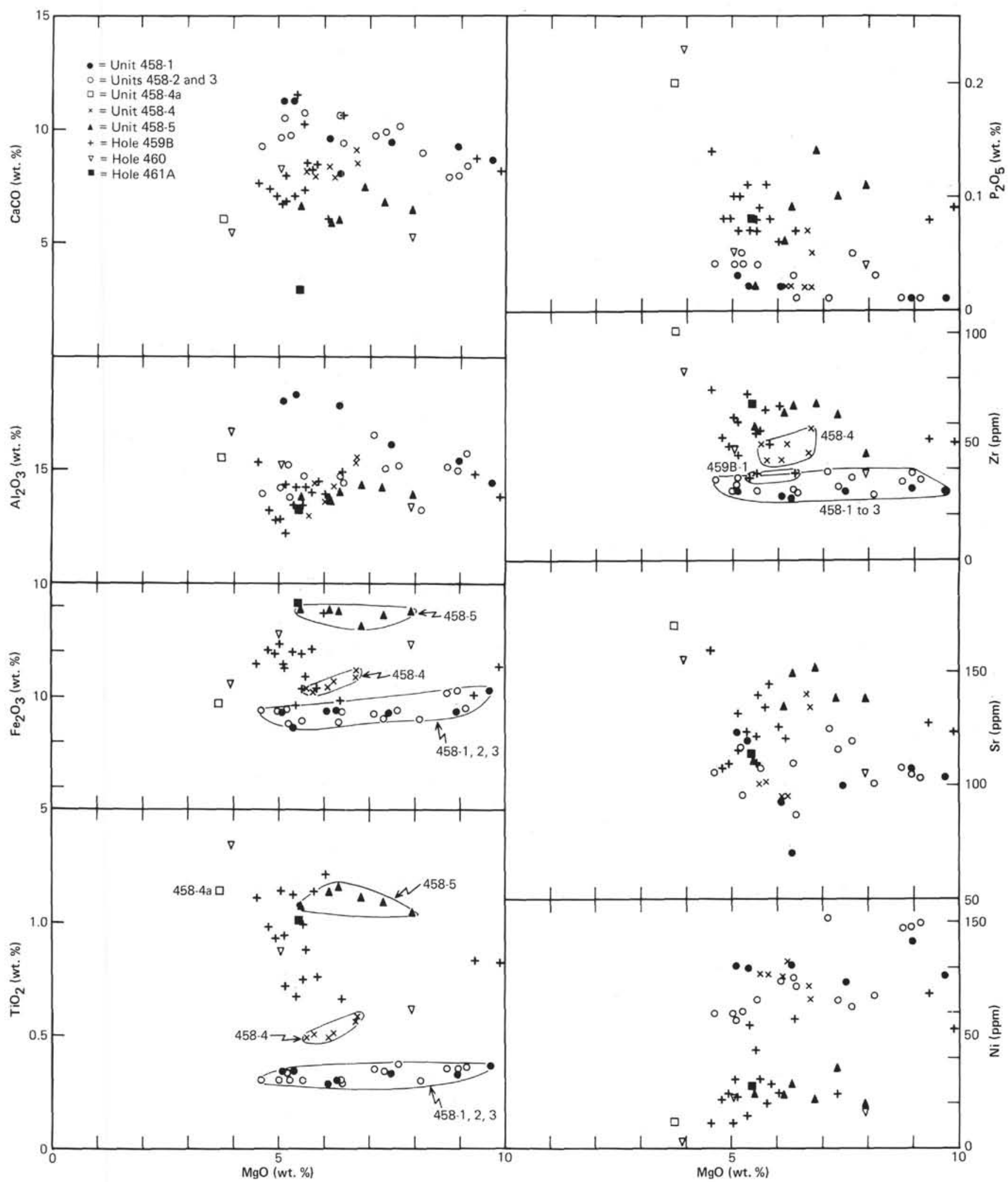

Figure 16. $\mathrm{MgO}$ variation diagram of selected major and trace elements for samples from Sites 458 through 461 . 


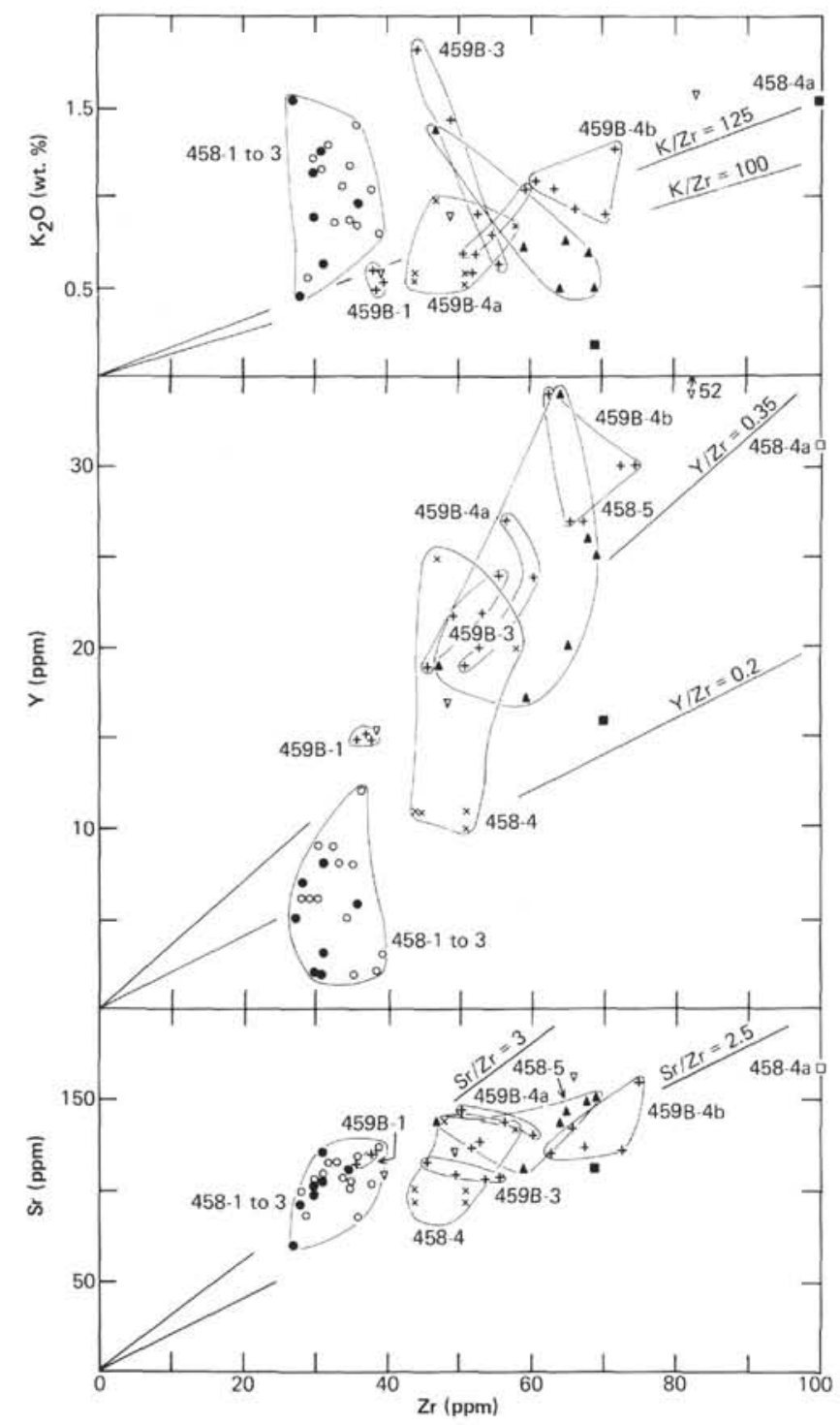

Figure 17. $\mathrm{K}_{2} \mathrm{O}, \mathrm{Y}$, and $\mathrm{Sr}$ versus $\mathrm{Zr}$ for samples from Sites 458 through 461 . (See Fig. 16 for symbols.)

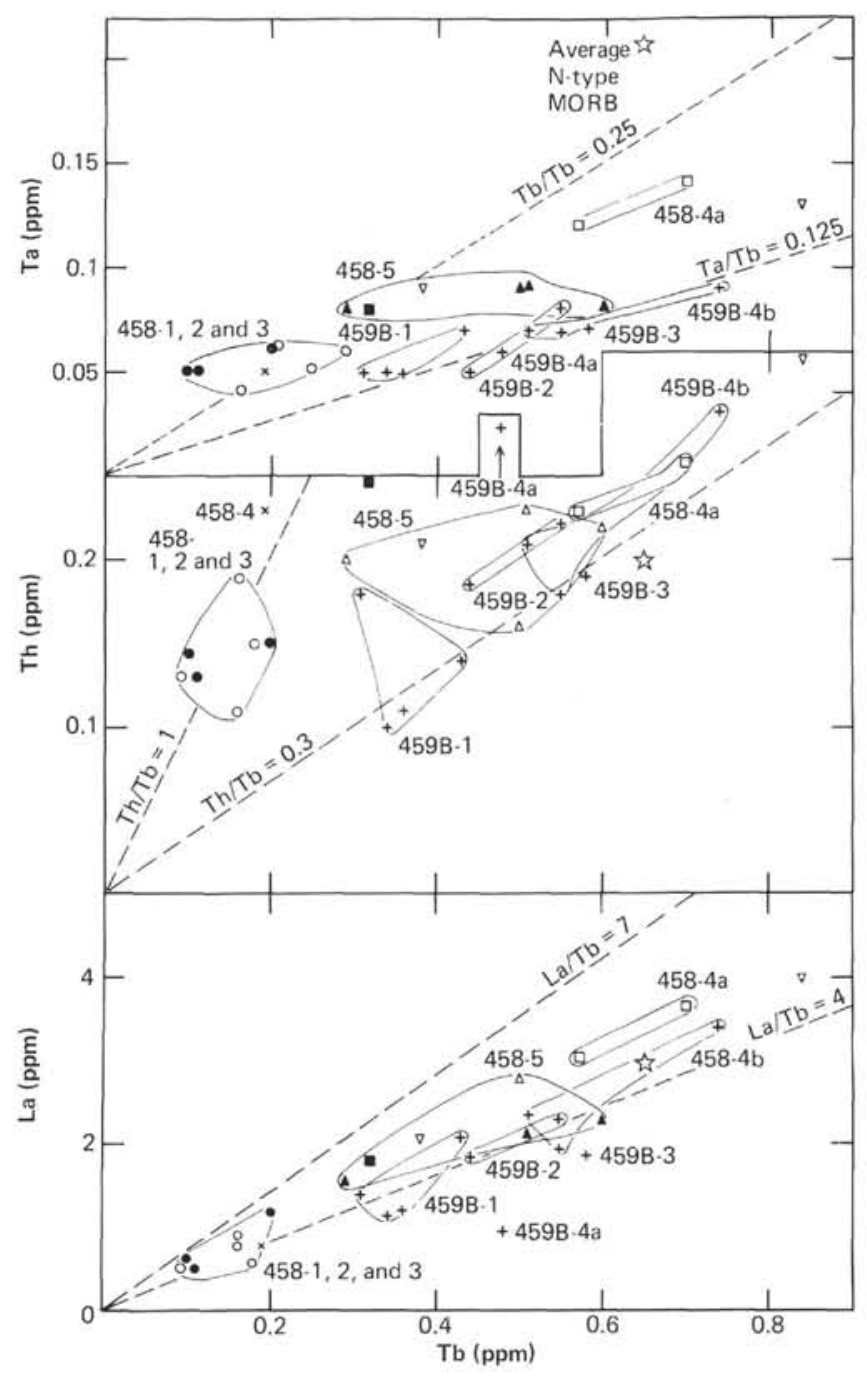

Figure 18. Ta, Th, and $\mathrm{La}$ versus $\mathrm{Tb}$ for samples from Sites 458 through 461 . (See Fig. 16 for symbols.) 


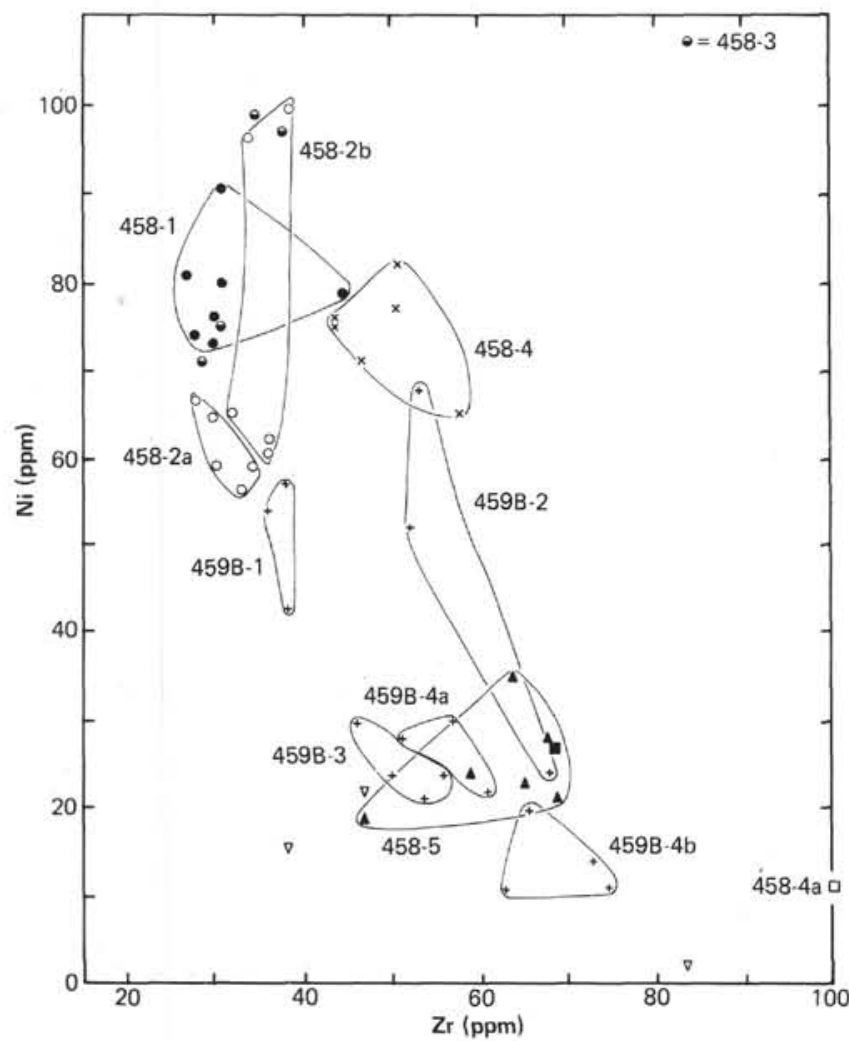

Figure 19. Ni versus $\mathrm{Zr}$ for samples from Sites 458 through 461 . (See Fig. 16 for symbols.)

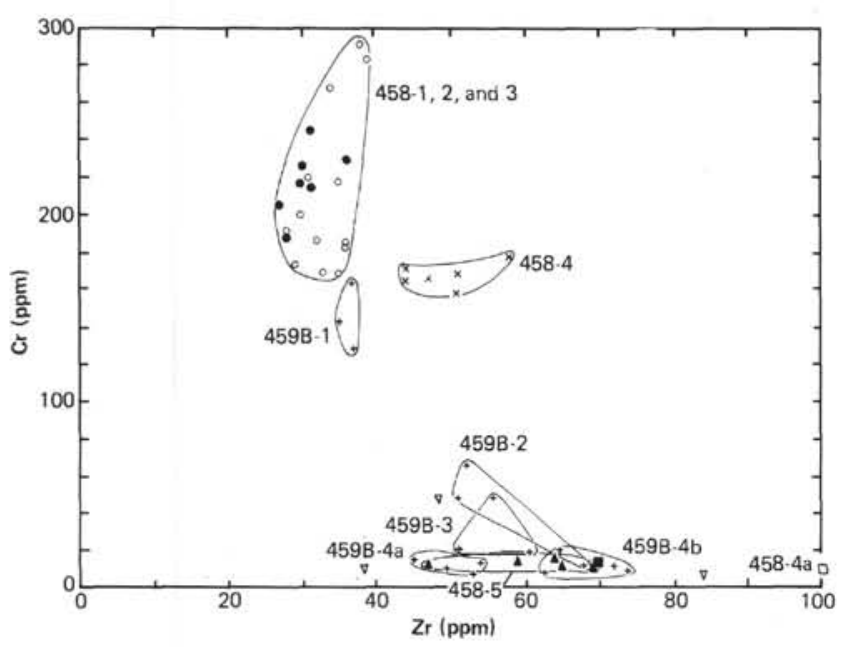

Figure 20. $\mathrm{Cr}$ versus $\mathrm{Zr}$ for samples from Sites 458 through 461 . (See Fig. 16 for symbols.)

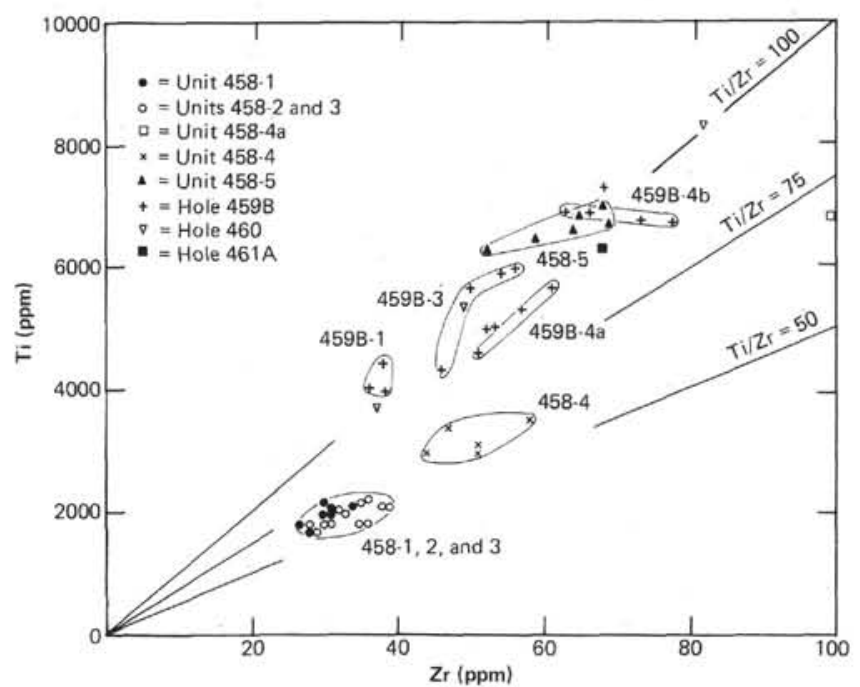

Figure 21. Ti versus $\mathrm{Zr}$ for samples from Sites 458 through 461 . (See Fig. 16 for symbols.) 


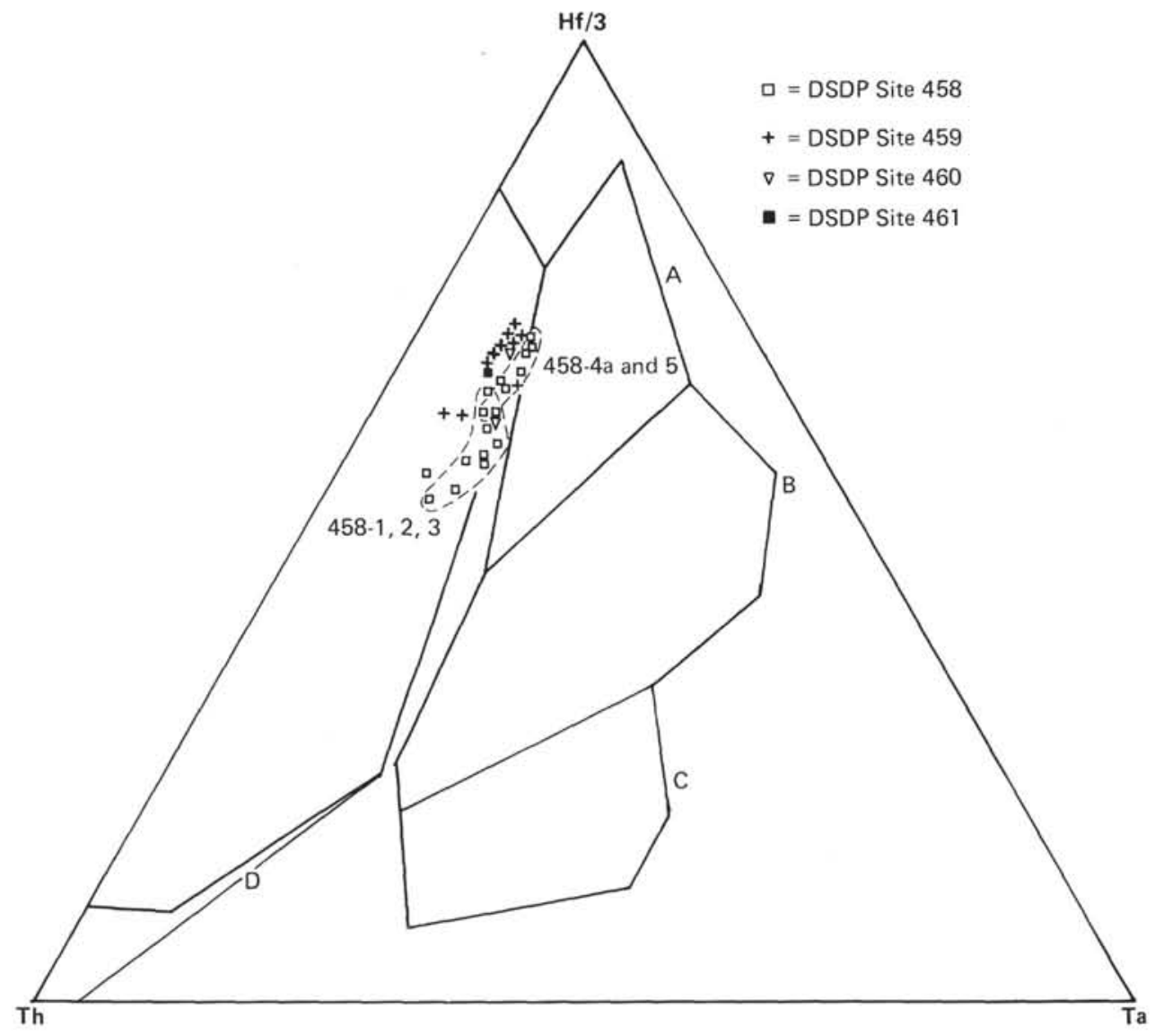

Figure 22. Th-Hf/3-Ta discrimination diagram for samples from Sites 458 through 461 . See Figure 11 for description of the marked areas.

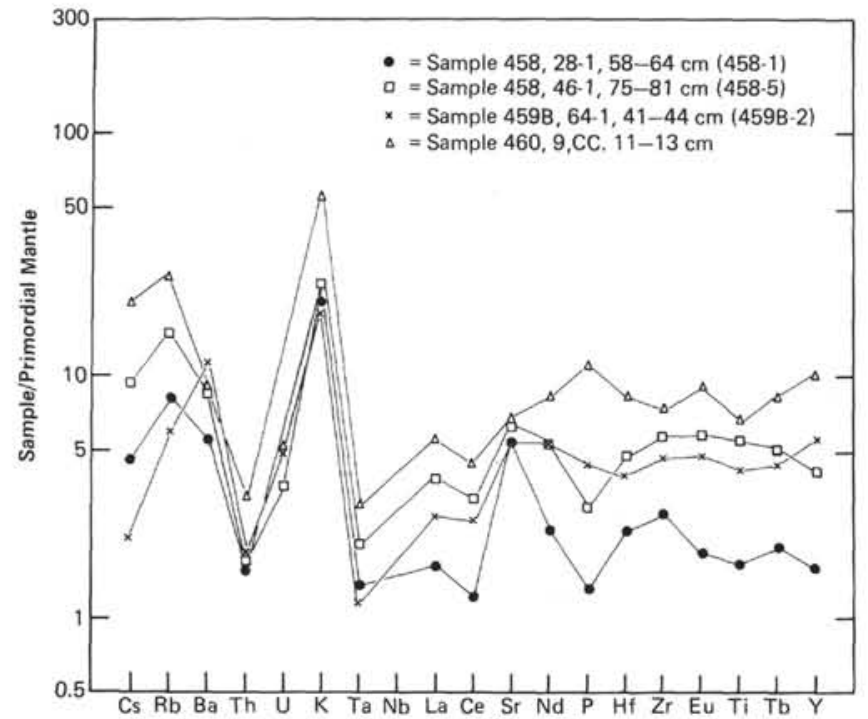

Figure 23. HYG element abundances of selected lavas from Sites 458,459 , and 460 normalized to estimated primordial mantle abundances (from Wood, 1979, except that a Ti value of $1500 \mathrm{ppm}$ is used here).

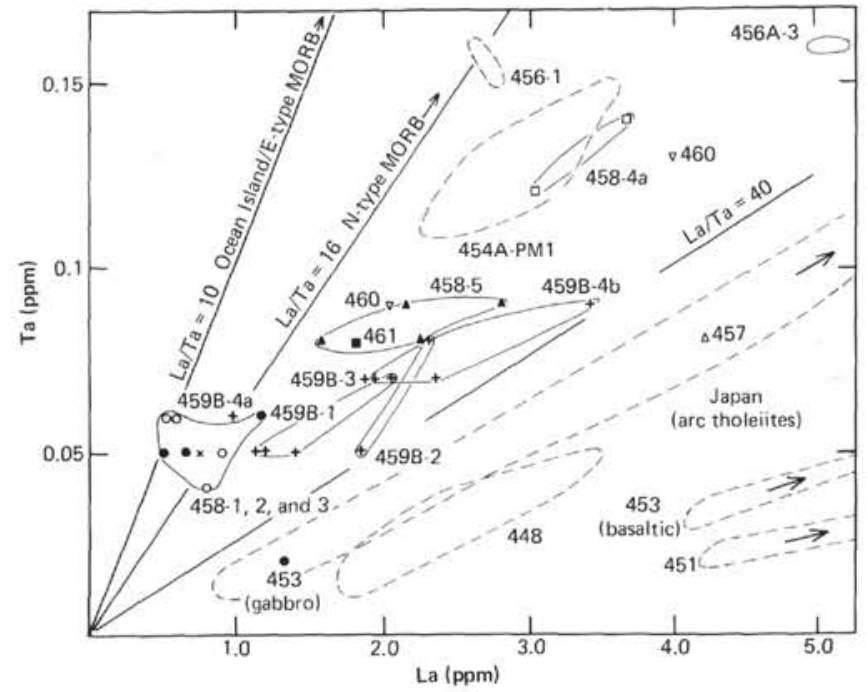

Figure 24. La versus Ta for Leg 60 samples. The fields of Japanese lava series and DSDP Leg 59 samples are from Wood et al., in press a and b. La/Ta ratios for E-type and N-type MORB are from Wood et al. 1979a. 


\section{APPENDIX}

Table 1. XRF sample descriptions (hand-specimen), Leg 60.

Sample

(interval in $\mathrm{cm}$ )

\section{Hole 453}

$42-1,16-18$

$47-1,99-101$

$49-1,56-61$

$49-3,52-58$

$50-2,37-42$

$52-1,96-102$

$52-2,94-97$

$53-3,0-5$

$54-1,40-47$

$54-2,84-91$

$54-3,6-10$

$55-2,14-18$

$55-3,25-29$

$55-3,90-94$

$55-4,144-148$

$56-2,33-35$

$56-2,85-90$

$57-1,30-35$

$57-3,8-12$

$57-4,123-130$

$57-4,36-81$

$58-1,6-10$

$59-1,13-15$

$59-1,47-52$

$63-1,0-5$
Mudstone-siltstone, dark greenish gray. Bioturbated mudstone, brownish green. Coarse-grained leuco gabbro, 70 percent feldspar, ferromagnesian minerals replaced by clays/chlorite/serpentine \pm amphibole(?) Fine- to medium-grained, leucocratic gabbro(?), pink coloration around feldspars, 60 percent felsic, altered ferromagnesian minerals [clay/chlorite(?)].

Coarse-grained leucocratic gabbro, 70 percent feldspar, altered ferromagnesian minerals [clays/chlorite/serpentine(?)]. Sparsely plagioclase-phyric basalt.

Heavily altered, leucocractic gabbro, 60 percent feldspar, altered ferromagnesian minerals [clays/chlorite/serpentine(?)] Gabbro, 50 percent feldspar, 50 percent altered ferromagnesian minerals [clays/ chlorite/serpentine(?)]

Badly altered, leucocratic(?) gabbro.

Arkose, various lithic fragments, one half of sample dark gray, possibly plagioclase-phyric basalt; the other half, brownish gray matrix with felsic grains.

Basalt (dolerite) plagioclase and possibly olivine or clinopyroxene-phyric.

Aphyric basalt clast, dark gray clay alteration products, fracture lined by red-brown clays.

Leuco-gabbro, 60 percent feldspar, 40 percent altered ferromagnesian minerals. Leuco-gabbro, 65 percent feldspar, 40 percent altered ferromagnesian minerals. Leuco-gabbro, 70 percent feldspar, 30 percent chloritic alteration products.

Leuco-gabbro, 70 percent feldspar, 30 percent chloritic alteration products, similar to previous sample.

Anorthosite, interstitial chlorite/clay. Gabbro, dark-gray feldspar, red-brown alteration products after ferromagnesian minerals.

Leuco-gabbro, 70 percent feldspar, 30 percent dark-brown and red-brown alteration products after ferromagnesian minerals. Coarse-grained leuco-gabbro, 70 percent feldspar, 30 percent interstitial altered ferromagnesian minerals.

Equigranular gabbro, 50 percent altered ferromagnesian minerals, 50 percent feldspar. Greenish gray, plagioclase-phyric metabasalt (15\% phenocrysts), occasional vesicles, some containing pyrite.

Sparsely feldspar-phyric (1-2\%), metavolcanic rock, aphanitic, Prussian gray groundmass, a few vesicles; quartz and carbonate vein cuts sample; quartz coating on one side of sample.

Gray-purple metavolcanic rock, carrying pyrite.

Prussian gray, plagioclase-phyric metabasalt(?), a few vesicles, some of which are carbonate-lined.
Table 1. (Continued).

Sample

(interval in $\mathrm{cm}$ )

\section{Site 454}

$454 \mathrm{~A}-5-1,2-8$

$454 \mathrm{~A}-5-3,106-110$

$454 \mathrm{~A}-5-4,15-18$

$454-6-2,102-106$

$454 \mathrm{~A}-8-1,2-7$

454A-10-1, 81-84

$454 \mathrm{~A}-11-1,40-44$

$454 \mathrm{~A}-11-4,71-75$

$454-12-1,100-104$

$454 \mathrm{~A}-12-2,26-29$

454A-14-1, 2-4

$454-15-1,13-16$

454A-16-1, 33-36

$454 \mathrm{~A}-16-1,111-114$

Site $\mathbf{4 5 6}$

456-16-1, 145-148

$456-16-2,92-96$

$456-17-1,95-99$

$456-18-1,50-53$

$456-19-1,18-21$

$456 \mathrm{~A}-10-1,25-27$

456A-11-1, 76-79

$456 \mathrm{~A}-12-1,11-15$

$456 \mathrm{~A}-13-1,23-26$
Medium-grained aphyric, altered greenish gray basalt, 2 percent vesicles.

Medium-grained, altered, gray-green basalt, 10 percent vesicles.

Medium-grained, altered, aphyric, gray-green basalt, 5 percent vesicles.

Medium- to coarse-grained basalt (dolerite), 2 percent vesicles; outer surface of sample covered by light-green clays.

Gray, aphyric, aphanitic basalt, 2 percent vesicles lined by dark gray-brown clay. Gray, medium-grained, altered basalt, 10 percent vesicles, 2 percent large vesicles (1-2 $\mathrm{mm}$ across), often lined by light-green clay, other vesicles $<0.5 \mathrm{~mm}$.

Gray, medium-grained, altered basalt, 10 percent vesicles, 2 percent $(1-2 \mathrm{~mm})$ lined by light-green clay, other vesicles $<0.5 \mathrm{~mm}$, similar to previous sample.

Gray, medium-grained, altered basalt, 5 percent vesicles $(<0.5 \mathrm{~mm})$.

Gray, medium-grained, altered basalt, 5 percent vesicles $(<0.5 \mathrm{~mm})$ similar to previous sample.

Gray, fine-grained, aphyric basalt, 10 percent vesicles $(<2 \mathrm{~mm})$, larger vesicles lined by blue-gray clay.

Gray, fine-grained, aphyric basalt, 10 percent vesicles $(<2 \mathrm{~mm})$

Gray, fine-grained, aphyric basalt, 10 percent vesicles, slightly altered.

Olive-green-gray, fine-grained, aphyric basalt, 5 percent vesicles, slightly altered. Olive-green-gray to gray, aphanitic, aphyric basalt, 2 percent vesicles.

Olive-green-brown, aphanitic, aphyric basalt, 3 percent large vesicles (1-2 mm), some with calcite and/or pyrite lining.

Fine-grained, blue-gray, plagioclase-phyric basalt. ( $5 \%$ phenocrysts, $0.5-2 \mathrm{~mm}$ across), 1 percent vesicles.

Fine-grained, blue-gray, plagioclase-phyric ( $5 \%$ phenocrysts, $0.5-2 \mathrm{~mm}$ across) basalt, 1 percent vesicles, some containing calcite crystals.

Medium-grained, olive-gray basalt, 3 percent vesicles, some lined by calcite and green clay. Sparsely plagioclase-phyric, dark gray, medium-grained basalts, 5 percent vesicles, sample cut by fracture lined by $\mathrm{Fe}$ oxides/ hydroxides.

Purple-gray mudstone.

Green-gray, aphyric, aphanitic metavolcanic rock, 10 percent vesicles $(<2 \mathrm{~mm})$, some contain pyrite.

Green-gray, fine-grained basalt, 2 percent vesicles, patches of dark-gray clay alteration products.

Dark-gray, aphyric, aphanitic basalt, 5 percent vesicles $(<2 \mathrm{~mm}), 5$ percent vesicles (2-10 $\mathrm{mm}$ ) lined by or filled by light-brown clays. 
Table 1. (Continued).

\begin{tabular}{cl}
\hline $\begin{array}{c}\text { Sample } \\
\text { (interval in cm) }\end{array}$ & \\
\hline 456A-14-1, 12-16 & $\begin{array}{l}\text { Dark-gray, aphyric, aphanitic basalt, 5 per- } \\
\text { cent vesicles }(<2 \mathrm{~mm}), 5 \text { percent vesicles } \\
(2-10 \mathrm{~mm}), \text { lined by yellow, red-brown and } \\
\text { purple alteration products. }\end{array}$ \\
456A-14-1, 38-42 & $\begin{array}{l}\text { Olive-gray, aphyric, aphanitic basalt, 2 per- } \\
\text { cent vesicles }(<0.5 \mathrm{~mm}), \text { concentric zoning } \\
\text { of alteration colors through sample suggests } \\
\text { part of pillow interior. } \\
\text { Gray, aphyric, fine-grained basalt, 4 percent } \\
\text { vesicles concentrated in "pipes," vesicles } \\
\text { often lined by gray or light-brown clays. }\end{array}$
\end{tabular}

\section{Hole 457}

$4, \mathrm{CC}$

\section{Hole 458}

27-1, 130-132

$28-1,58-64$

28-1, 125-130

28-1, 140-146

29-1, 54-57

$29-2,37-42$

$30-1,56-59$

$31-1,39-41$

$31-1,131-136$

$32-1,116-119$

$32-3,34-36$

$33-2,19-22$

$34-1,39-42$

$35-1,42-45$

$35-2,69-73$

$36-1,27-31$

$37-1,52-55$

$37-2,62-64$

$38-1,51-53$

$39-1,37-40$

$40-2,90-93$
Tan-colored piece of pumice, very soft.

Olive-green, fine-grained sandstone, cut by carbonate-lined fracture.

Heavily altered, light-green-gray, spherulitic

Heavily altered, light-green-gray, spherulitic basalt.

Dark gray, aphyric, fine-grained basalt, 3 percent vesicles $(<2 \mathrm{~mm})$, a few larger vesicles lined by blue-gray clay. .

Olive-green, fine-grained, aphyric basalt, 1 percent vesicles $(<1 \mathrm{~mm})$.

Dark-green-gray, fine-grained aphyric, altered basalt, $<1$ percent vesicles $(<1 \mathrm{~mm})$. Heavily altered, olive-green, spherulitic basalt, 5 percent vesicles $(2-5 \mathrm{~mm})$, lined by gray-blue clay and white mineral (zeolite?). Heavily altered, light olive-green, finegrained, aphyric basalt, one vesicle $(2+2$ $\mathrm{mm})$.

Light-gray (green tinges), fine-grained, aphyric basalt, 3 percent vesicles $(<1 \mathrm{~mm})$. Light-gray-green, medium-grained, aphyric basalt, 1 percent vesicles $(<1 \mathrm{~mm})$.

Light-gray-green, aphyric, aphanitic basalt, 5 percent vesicles $(<1 \mathrm{~mm})$.

Gray-green, medium-coarse grained (ca. 1 $\mathrm{mm})$ basalt, few vesicles $(<1 \mathrm{~mm})$.

Light-green-gray, medium-grained, basalt, 2 percent vesicles $(<1 \mathrm{~mm})$, one surface of sample is a fracture covered by a light-olivegreen clay and carbonate.

Light-green-gray, medium-grained, aphyric

basalt, 5 percent vesicles $(<1 \mathrm{~mm})$; one surface of sample is a fracture; basalt heavily altered, but no coating of secondary minerals.

Light gray, aphyric, aphanitic basalt, several trains of small vesicles $(<0.5 \mathrm{~mm})$.

Light gray-green, aphyric, aphanitic basalt, few vesicles, cut by carbonate and clay/chlorite(?)-lined vein.

Gray-green, fine-grained, aphyric basalt. few vesicles.

Battleship-gray, fine-grained basalt, 2 percent vesicles $(<2 \mathrm{~mm})$, odd plagioclase(?) phenocrysts(?).

Gray, very fine-grained basalt, 5 percen vesicles, often lined or infilled by gray clay and calcite.

Battleship-gray, aphyric, aphanitic basalt, 1 percent vesicles $(<0.5 \mathrm{~mm})$, sample cut by carbonate-lined fracture. basalt, one large vesicle $(5 \times 3 \mathrm{~mm})$.

Gray-green, medium-grained, aphyric basalt,

Table 1. (Continued).

Sample
(interval in cm)

$41-1,22-26$

$42-1,61-64$

$42-1,86-88$

$43-1,118-121$

$44-1,53-60$

$45-1,8-12$

$45-1,24-27$

$46-1,75-81$

$46-1,83-86$

$47-1,67-71$

$48-1,79-82$

$49-1,136-138$

Hole 459

$60-2,80-83$

$61-1,115-118$

$61-2,47-50$

$63-1,53-54$

$64-1,41-44$

$65-1,59-63$

$66-1,73-77$

$66-2,147-150$

$67-1,118-120$
Heavily altered, olive-gray, aphyric, aphanitic basalt, 3 percent vesicles $(<0.5 \mathrm{~mm})$.

Green-gray, fine-grained aphyric basalt, few vesicles, slickenside surface on sample covered by chlorite.

Dark-gray, aphyric, aphanitic basalt, 2 percent vesicles often surrounded by light-gray alteration zone and lined by light-blue clay and zeolites or chalcedony. Sample cut by zeolite or chalcedony-lined vein.

Gray, fine-grained basalt, 2 percent vesicles, heavily altered to green clays, a few zeolites(?) in vesicles.

Gray, aphyric, aphanitic basalt, 2 percent vesicles lined by zeolites and blue-gray clay. Gray, aphyric, aphanitic basalt, 2 percent vesicles lined by zeolites and blue-gray clay, similar to previous sample.

Olive-green-gray, aphyric, fine-grained basalt, 10 percent vesicles $(<3 \mathrm{~mm})$.

Gray-green, fine-grained, aphyric basalt, few vesicles.

Gray-green, aphyric, aphanitic basalt, few vesicles, one vesicle filled by a zeolite(?), trains of fine vesicles $(<0.5 \mathrm{~mm})$.

Light-green-gray, aphyric, aphanitic basalt; three parallel trains of fine vesicles $(<0.5 \mathrm{~mm})$ cut sample, plus a few larger vesicles (1-2 mm). Gray-green, aphyric, aphanitic basalt, lustrous, black glassy margin on one side of sample, very fresh, but coating of clays/chlorite on outer surfaces.

Olive-green-gray, fine-grained, aphyric basalt, 5 percent vesicles, gray-blue clay lining to vesicles.

Gray-green, medium-grained inequigranular basalt, 3 percent vesicles $(<1 \mathrm{~mm})$. Light-gray-green, medium-grained inequigranular basalt, 15 percent vesicles $(<2 \mathrm{~mm})$, specks of $\mathrm{Fe}^{\mathrm{III}}$ oxides present.

Green-gray, medium-grained inequigranular basalt, 2 percent vesicles $(<2 \mathrm{~mm})$, mesostasis altered to light-olive-green and tan clays.

Olive green-gray, fine-grained aphyric basalt, 2 percent vesicles, generally $<0.5 \mathrm{~mm}$, a few $1-2$ $\mathrm{mm}$.

Dark green-gray, fine-grained, aphyric basalt, 3 percent vesicles $(<1 \mathrm{~mm})$.

Heavily altered, dark green-gray, aphyric, aphanitic basalt, 1 percent vesicles $(<1 \mathrm{~mm})$; sample also includes part of glassy margin (black, lustrous, relatively fresh), and is cut by carbonate and clay and/or chlorite(?)-lined vein.

Heavily altered, olive-green-brown, mediumgrained, inequigranular basalt, 3 percent vesicles $(<2 \mathrm{~mm})$, brown clay lining to some vesicles.

Heavily altered, olive-green-brown, mediumgrained, inequigranular basalat, 1 percent vesicles $(<2 \mathrm{~mm})$, one large vesicle $(5 \mathrm{~mm})$. Olive-green, medium-grained, inequigranular basalt, 3 percent vesicles, bright olive-green secondary mineral-malachite? Infilling and replacing mesostasis near some vesicles. 
Table 1. (Continued).

Sample

(interval in $\mathrm{cm}$ )

$68-1,51-54$

Olive-green, fine- to medium-grained, inequigranular basalt, bright-olive-green mineral (malachite?), replacing mesostasis and lining fracture with carbonate.

$69-1,144-146$

Gray, fine-grained, aphyric basalt, 2 percent vesicles, sample surface covered by green and brown clays.

$69-3,83-86$

Olive-green, very fine grained aphyric basalt, 2 percent vesicles $(<2 \mathrm{~mm})$.

$70-1,49-53$

Dark-olive-green-gray, fine-grained, aphyric basalt, 4 percent vesicles $(<0.5 \mathrm{~mm}), 1$ percent vesicles (1-2 mm); sample cut by slickensided, chlorite-lined fracture.

$71-2,38-40$ Heavily altered, olive-green-gray, finegrained basalt, 3 percent vesicles $(<1 \mathrm{~mm})$.

$71-2,105-108$ Heavily altered, olive-green-gray, finegrained basalt, 3 percent vesicles $(<1 \mathrm{~mm})$; similar to previous sample, cut by slickensided chlorite-lined fracture.

$73-1,38-40$

Heavily altered, olive-green-gray, finegrained, aphyric basalt, 3 percent vesicles, similar to previous two samples.

$73-3,118-120$

Heavily altered, olive-green-gray, finegrained, aphyric basalt, 2 percent vesicles $(<2 \mathrm{~mm})$.

Site $\mathbf{4 6 0}$

460-9, CC, 7-8 (\#2) Heavily altered, olive-green-brown, finegrained, plagioclase-phyric $(5 \%)$ basalt, 1 percent vesicles $(0.5-2 \mathrm{~mm})$.

460A-9, CC, 11-13 Olive-green-gray, aphanitic, aphyric basalt, 2 percent vesicles $(<5 \mathrm{~mm})$.

460A-11-1, 29-33 Green-gray, medium-grained basalat, odd vesicle $(<2 \mathrm{~mm})$, lined by dark-green clay.

Hole 461A

$3-1,60-62$

Green-brown, fine-grained, aphyric basalt, light-tan and dark-green clays \pm chlorite coating surface of sample, cut by fracture lined by $\mathrm{Fe}^{\mathrm{III}}$ oxides. 